Florida International University FIU Digital Commons

3-19-2015

\title{
Children's Literature, Ideology, and Cultural Identity Before and After the Cuban Revolution
}

Zeila M. Frade

Florida International University, salmantina05@gmail.com

DOI: $10.25148 /$ etd.FI15032163

Follow this and additional works at: https://digitalcommons.fiu.edu/etd

Part of the Latin American Languages and Societies Commons, and the Other Languages, Societies, and Cultures Commons

\section{Recommended Citation}

Frade, Zeila M., "Children's Literature, Ideology, and Cultural Identity Before and After the Cuban Revolution" (2015). FIU Electronic Theses and Dissertations. 1831.

https://digitalcommons.fiu.edu/etd/1831 


\title{
FLORIDA INTERNATIONAL UNIVERSITY
}

Miami, Florida

\section{LITERATURA INFANTIL, IDEOLOGÍA E IDENTIDAD NACIONAL ANTES Y DESPUÉS DEL TRIUNFO DE LA REVOLUCIÓN CUBANA}

A dissertation submitted in partial fulfillment of the requirements for the degree of DOCTOR OF PHILOSOPHY

\author{
in \\ SPANISH \\ by \\ Zeila Frade
}

2015 
To: $\quad$ Dean Michael R. Heithaus

College of Arts and Sciences

This dissertation, written by Zeila Frade, and entitled Literatura Infantil, Ideología e Identidad Nacional Antes y Después del Triunfo de la Revolución Cubana, having been approved in respect to style and intellectual content, is referred to you for judgment.

We have read this dissertation and recommend that it be approved.

Santiago Juan-Navarro

Maida Watson

Sherry Johnson

Erik Camayd-Freixas, Major Professor

Date of Defense: March 19, 2016

The dissertation of Zeila Frade is approved.

Dean Michael R. Heithaus

College of Arts and Sciences

Dean Lakshmi N. Reddi

University Graduate School

Florida International University, 2015 


\section{DEDICATORIA}

A mis padres y a Frey, por todo 


\section{AGRADECIMIENTOS}

La culminación de esta tesis doctoral no hubiera sido posible sin la colaboración y el apoyo de todos los profesores en mi comité. Agradezco en especial a mi director, el Dr. Erik Camayd-Freixas, sus valiosas sugerencias desde el comienzo; su conocimiento y guía fueron determinantes a lo largo del proceso de investigación y de escritura. A la Dr. Watson quiero darle las gracias por sus útiles correcciones y la insistencia. La ayuda de la Dra. Johnson en la elaboración de la propuesta de tesis fue fundamental y las fuentes bibliográficas recomendadas por el Dr. Juan-Navarro enriquecieron mi investigación.

El Dissertation Evidence Acquisition Fellowship otorgado por Graduate School me permitió dedicar un semestre a la labor investigativa y progresar considerablemente. Igualmente agradezco a Cuban Heritage Collection (CHC) de la Universidad de Miami por concederme una beca para continuar mi investigación y finalizar los dos últimos capítulos. Todo el material que encontré allí fue de crucial importancia. Deseo agradecer a todos en la colección su ayuda, pero en especial a Mei Méndez, Rosa Monzón y Esperanza Bravo de Varona.

Extiendo mi agradecimiento a todas las personas que en algún momento colaboraron con sus ideas y recomendaciones. Entre ellas se encuentra el Dr. Jorge Duany, director del Cuban Research Institute de FIU, quien no sólo me animó a solicitar la beca de CHC, sino que amablemente me extendió una invitación para exponer el resultado de mi investigación como parte de las presentaciones que organiza el instituto. Este proyecto no habría progresado de la misma manera sin la minuciosa corrección y el constante apoyo de la Dra. María Gracia Pardo. A ella le agradezco su 
disposición para compartir su vasto conocimiento y su pasión por la literatura en general, y en especial, por la infantil. Mi más profunda gratitud es para mis padres, por darme el mejor de los ejemplos y para Frey, por confiar en mí y apoyarme en éste y todos mis proyectos. 


\section{ABSTRACT OF THE DISSERTATION \\ LITERATURA INFANTIL, IDEOLOGÍA E IDENTIDAD NACIONAL ANTES Y \\ DESPUÉS DEL TRIUNFO DE LA REVOLUCIÓN CUBANA \\ by \\ Zeila Frade}

Florida International University, 2015

Miami, Florida

Professor Erik Camayd-Freixas, Major Professor

Mediante de un acercamiento cronológico, esta disertación analiza la función de la ideología como herramienta poderosa para construir la nación y moldear al futuro ciudadano en la narrativa infantil cubana pre y pos-revolucionaria. Aunque una tradición y un proceso de formación de identidad nacional anteceden la literatura infantil publicada antes del triunfo de la Revolución, en los períodos posteriores existe una estrecha relación entre el contexto social de los textos y su función ideológica. Partiendo de “La Edad de Oro” (1889) de José Martí, este estudio se enfoca en los cambios socio-culturales que influyen en el desarrollo de una narrativa infantil nacional que transita del didacticismo más férreo a una variada exploración temática. Por encontrarse entre la Colonia y la etapa revolucionaria, el período republicano ha recibido poca atención crítica, marginado a veces de la herencia literaria de la nación. Sin embargo, el análisis de varios textos representativos en este período permite apreciar la integración de un pensamiento cubano desde búsquedas y posiciones muy diferentes a las del período siguiente, de 1959 a 1989. A partir de 1990 una diversificación temática fomenta objetivos muy distantes del enunciado didáctico. 
Este estudio concluye que en contraste con los pertenecientes a generaciones anteriores, en los escritores formados dentro de la Revolución, especialmente a partir de la década del ochenta, existe un interés especial por abordar temáticas inexploradas en la literatura infantil tradicional. El divorcio, la muerte, los conflictos generacionales y las diferencias raciales son sólo algunos de los temas que matizan la narrativa infantil posrevolucionaria, cuyos presupuestos ideo-estéticos, se encuentran intrínsecamente relacionados al contexto sociocultural. 
TABLA DE CONTENIDO

CAPÍTULO

PÁGINA

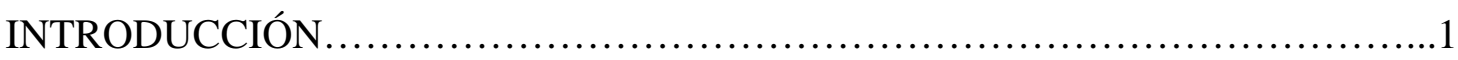

I. REPRESENTACIÓN Y CONFORMACIÓN DE LA IDENTIDAD

NACIONAL EN LA LITERATURA INFANTIL CUBANA:

MOLDEANDO

AL FUTURO

CIUDADANO..........................................................

Ideología y formación ética del hombre ideal en La Edad de Oro de José

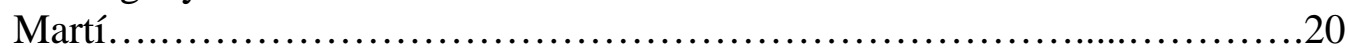

II. ENTRE COLONIA Y REVOLUCIÓN: UN ACERCAMIENTO A LOS TEXTOS INFANTILES DE LA REPÚBLICA (1902- 1958).............................45

Construcción de una identidad nacional: El proceso cubano.....................56

III. CONFIGURACIÓN DE LA NARRATIVA INFANTIL CUBANA POSREVOLUCIONARIA (1959-1989): EL NIÑO COMO CIUDADANO

IDEAL

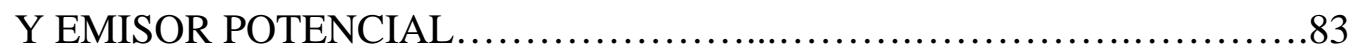

IV. EL ESCRITOR, EL LECTOR Y EL ENTORNO A PARTIR DE 1990:

RECORRIDO POR UN PERÍODO ESPECIAL DE MARCADA

EXPLORACIÓN TEMÁTICA.............................................119

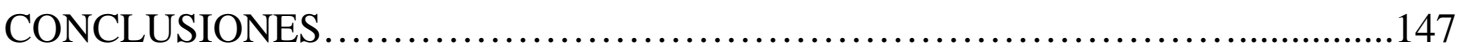

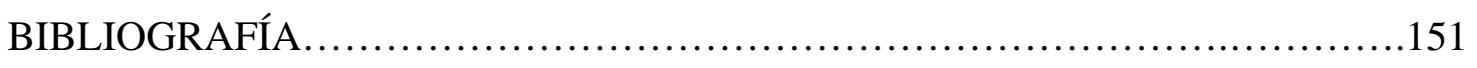

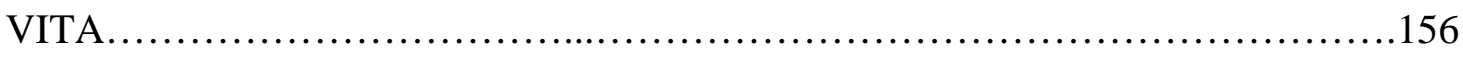




\section{INTRODUCCIÓN}

La literatura infantil cubana ha recorrido un camino de paulatino desarrollo, superando períodos de escasa producción y estableciendo un sólido acervo de escritores y obras. Su decurso histórico se ha enriquecido con creaciones que exploran los distintos géneros literarios y que reflejan la diversidad de temáticas, estilos e ideologías que marcan su contexto socio-cultural. Las necesidades e inquietudes de niños y jóvenes se han percibido desde diversas perspectivas y el didacticismo, la exaltación de lo autóctono y la canalización de la conciencia nacional han poblado las producciones literarias de cada período. En 1959 se inicia una nueva etapa para la cultural nacional y en décadas posteriores la literatura infantil alcanzará su mayor auge. Para el nuevo gobierno es de cardinal importancia moldear al futuro ciudadano de cada generación conforme a sus postulados ideológicos, por lo que percibe en el lector infantil al destinatario ideal para desarrollar su proyecto. Una estrecha relación entre la evolución sociopolítica y las transformaciones literarias marca la literatura infantil cubana postrevolucionaria.

A pesar del significativo incremento en la producción de textos literarios infantiles en Cuba a partir de 1959 y de los acercamientos críticos existentes, etapas como la República, que además es un punto de contraste significativo con el período posterior, aún no se han estudiado lo suficiente. Edward Muller observa que "few areas of

Latin America are so little studied as the Caribbean” (88) ${ }^{1}$. En la literatura infantil cubana es fundamental indagar en los rasgos distintivos y las cualidades literarias de los textos

\footnotetext{
${ }^{1}$ Citado en González, Ann. Resistance and Survival: children's narrative from Central America and the Caribbean. Tucson: University of Arizona Press, 2009.
} 
teniendo en cuenta la relación entre contexto histórico y producción, contemplando no sólo las etapas posrevolucionarias sino las anteriores a 1959.

Algunos estudios sobre la narrativa infantil cubana ofrecen un panorama cronológico de su desarrollo. En su ensayo "Panorama de literatura infantil” (1987), la investigadora cubana Alga Marina Elizagaray alude a La Edad de Oro (1899) de José Martí como obra cumbre de las letras cubanas en el siglo XIX. La cronología que propone la escritora excluye la etapa republicana (1902-1958) y pasa de la publicación de la obra martiana mencionada a 1959, haciendo más hincapié en el período de 1972-1975 por la proliferación de premios anuales de literatura. Elizagaray realiza un listado de los escritores más destacados de cada etapa y finaliza comentando el estado de las editoriales cubanas y la distribución de las obras infantiles en la isla hasta 1987.

Otro escritor e investigador literario cubano que ofrece un panorama desde 1959 hasta 1988 en su Antología de la literatura infantil cubana (1996) es Antonio Orlado Rodríguez. En el prólogo a la obra, Rodríguez le propone al lector "ser testigo del proceso de surgimiento, desarrollo y consolidación de nuestra narrativa contemporánea para los niños” (6) y aborda en una primera instancia los valores éticos y literarios de $L a$ Edad de Oro de José Martí. Rodríguez presenta el cuaderno Navidades para un niño cubano (1959) como antecedente de la narrativa revolucionaria y prosigue a describir la década de los sesenta como etapa de "gestación y quehacer laborioso" (8). En esa época aparece el cuento "La lechuza ambiciosa” de Onelio Jorge Cardoso, texto que el investigador cubano considera "kilómetro cero de la nueva narrativa infantil surgida en consonancia con las transformaciones sociales que revitalizan la cultura del país” (7-8). La recopilación de Rodríguez incluye obras representativas de los escritores más 
destacados en la década del setenta y del ochenta, época que considera de "eclosión de autores” (12).

Los estudios de Alga Marina Elizagaray y Antonio Orlando Rodríguez parten de un acercamiento cronológico: de 1972 a 1975 y de 1959 a 1989, respectivamente. Con el objetivo de ofrecer al lector un panorama de la literatura infantil cubana, ambos realizan una selección de los escritores más representativos de las etapas a las que dedican su estudio o antología, en el caso del segundo. Por su parte, el escritor e investigador cubano Omar Felipe Mauri ofrece una periodización de la literatura infantil nacional a partir de estudios recientes ${ }^{2}$ en su ensayo "Perfil de la literatura infantil cubana en vísperas de un nuevo milenio” (2001). Para Mauri Sierra, reconocer la tradición que antecede la narrativa infantil cubana es necesario, por lo que señala La Edad de Oro de José de Oro (1889) de José Martí como paradigma de la literatura infantil. Sin embargo, en su ensayo aclara que "ya a inicios del siglo XIX, siendo Cuba de España, existía en la isla una literatura nacional” (8) y que ésta “cristaliza primero en la poesía, y se extiende a la oratoria, el periodismo, la narrativa y el ensayo” (8). Optando también por un enfoque cronológico, el acercamiento de Mauri Sierra ahonda un poco más en las obras para niños escritas durante la República, aunque no incluye este período en su periodización. Sobre el estado de la literatura infantil republicana nos revela que "vivió precariamente bajo el desprecio oficial, el menosprecio intelectual y los altos precios del mercado” (10). Si bien el crítico arroja luz sobre los males de la República, señalando el costoso y complicado proceso editorial y la ausencia de medios propios para la producción y el comercio, no

\footnotetext{
${ }^{2}$ Omar Felipe Mauri Sierra refiere a las etapas de desarrollo de acuerdo con José Antonio Gutiérrez, "Primeras impresiones sobre los aportes generacionales, las tendencias y temáticas visibles en la poesía infantil de la Revolución cubana” en En Julio como en Enero, op. cit., pág. 28, y en las 20-27
} 
vacila en reconocer los esfuerzos de escritores y pedagogos republicanos para combatir la influencia extranjera y contribuir a la formación de la nacionalidad. La primera etapa de desarrollo en la periodización de Mauri Sierra va de 1959 hasta 1965 y se considera de formación. Se trata de una época en que el cuento es el género que se impone, seguido después por el periodismo y la poesía, pero siempre a disposición, explícita o no, del proceso de educación en la isla (Mauri Sierra 14). La lucha contra la tiranía de Fulgencio Batista como reciente hecho histórico afecta el compromiso de los escritores con las circunstancias históricas vividas y "la literatura para niños y jóvenes explicita la relación íntima entre el texto y el contexto, con obras de gran intensidad testimonial e ideológica” (13). Una de las obras más representativa de este período es la noveleta Las Aventuras de Guille (1965) de Dora Alonso. El segundo ciclo abarca desde 1966 hasta 1972 y se considera de “movilización temática y genérica” (14). Mauri Sierra observa que lo más destacado de este período es la creación de dos vertientes en la literatura infantil. La primera de ellas sigue cumpliendo el propósito de educar y entretener, mientras que la otra recurre a la imaginación y a la palabra como aliadas que permitan la experimentación con nuevas formas para relatar (15). El tercer período al que Mauri Sierra hace referencia abarca desde 1973 hasta 1979 y es de “especialización y perfeccionamiento” (17). A pesar de coincidir con una etapa de marcada complejidad en el devenir intelectual de la isla, dadas las tensiones entre el Estado y la intelectualidad, Mauri Sierra afirma que en la literatura infantil hubo una "relativa independencia” y que “la extensa relación de obras demuestra el alto nivel cualitativo que se alanzó entonces” (18). Como obras destacadas del período señala, entre otras, los poemarios Juegos y otros poemas (1974) de Mirta Aguirre, Por el mar de las Antillas anda un barco de papel (1979) de Nicolás Guillén y 
Palomar (1979) de Dora Alonso y los suscribe como ejemplos de "renovación lírica, capacidad de aprehender el mundo infantil, lo criollo, lo caribeño y las tradiciones hispanoamericanas” (18). Para el crítico, la etapa de 1980 sería el momento más importante de la serie infantil y apunta que la prosa narrativa “continúa siendo el cauce mayor de la literatura infantil cubana” (18). El último ciclo en la periodización de Mauri Sierra comienza a partir de 1988 y se considera de universalización.

El acercamiento de esta disertación relaciona la evolución socio-política que comienza en 1959 y el desarrollo literario que ocurre a partir de ese momento. Este estudio también parte de un acercamiento cronológico, sin embargo, antes de abarcar la narrativa pos-revolucionaria toma La Edad de Oro (1889) de José Martí como precedente de cardinal importancia para comprender la trayectoria de la narrativa infantil nacional y luego aborda la época republicana: 1902 a 1958. Un acercamiento a las temáticas y el discurso en las obras infantiles de la República permite apreciar la integración de un pensamiento cubano desde búsquedas y posiciones filosóficas diferentes, en tanto supone un punto de contraste con la etapa siguiente. Debido a la instauración de un sistema socio-político a partir del triunfo de la Revolución, el siguiente período es de 1959 a 1989 y se divide en dos etapas: una primera que se ocupa de los años sesenta y setenta y una segunda etapa que se enfoca en la década del ochenta. Es importante delimitar estas dos etapas dada la reorganización de instituciones educativas y la creación de organismos culturales que ocurre durante la primera y la aparición de un grupo de escritores que empieza a crear una literatura diferente en la segunda. El período de 1990 a 2010 finaliza el recorrido que este estudio realiza por la literatura infantil cubana. La etapa inicial de la década de los noventa tuvo una especial repercusión para la isla ya que supuso, tras la 
caída del campo socialista, una época de extrema escasez en todos los sentidos. Durante lo que se ha denominado Período Especial, las carencias de los escritores se hayan frente a la problemáticas del ser humano y el entorno por lo que resulta importante acercarse las producciones de este período no sólo para ver cómo ha cambiado la literatura infantil a partir de 1959 en contraste con las etapas precedentes, sino cuáles han sido los cambios dentro de las distintas etapas posrevolucionarias ${ }^{3}$.

En la construcción de una nación, la ideología le permite a las estructuras de poder inculcar determinados valores socio-políticos que moldeen al futuro ciudadano de cada generación. En el caso de Cuba, un acercamiento diacrónico a su literatura infantil resulta idóneo para argumentar cómo a través de ella la tensión entre función estética e ideología ha marcado los diferentes períodos históricos. Inicialmente definida por los filósofos alemanes Karl Marx y Friedrich Engels como "The ideas of the ruling class are in every epoch the ruling ideas...The class which has the means of material production at its disposal, has control at the same time over the means of mental production”, ${ }^{\text {, otros }}$ filósofos adaptarían el concepto de ideología a su contexto histórico. El italiano Antonio Gramsci introduce el concepto de ‘hegemonía’, planteando que el poder de la ideología se deriva principalmente del consenso en lugar del uso de la fuerza. Por su parte, el filósofo francés Louis Althusser articula dos tipos de aparatos con respecto a la ideología:

\footnotetext{
${ }^{3}$ El estudio La narrativa de la Revolución cubana (1975) de Seymour Menton ofrece un panorama de la trayectoria narrativa desde el año 1959 hasta 1971. Menton propone las etapas de 1959 hasta1961, de 1961 hasta 1965 y de 1966 hasta 1970. En su obra Caminata por la narrativa latinoamericana (2002) presenta una cuarta etapa, que va de 1971 a 1974. La periodización de Menton incluye dos etapas más que abarcan de 1975 hasta 1987 y finalmente la última década del siglo XX. En 1971 el portavoz de asuntos culturales cubanos Lisandro Otero propone una división diferente a la de Menton, aunque coinciden en la primera etapa de 1959-1961.

${ }^{4}$ Marx and Engels, The German Ideology quoted in Peter Brooker, A Concise Clossary of Cultural Theory
} 
el represivo de estado y el ideológico. Mientras que el aparato represivo tiene el fin explícito de ejercer control, el aparato ideológico carece de él. La ideología y el discurso son, entonces, los conceptos principales para comprender la transmisión de ideas. En su marco teórico, esta disertación emplea el concepto de ideología a partir de las acepciones que Gramsci y Althusser formulan con el objetivo de dilucidar los valores hegemónicos mediante la conexión entre ideología y discurso.

\section{Marco histórico de la literatura infantil cubana}

El siglo XX fue escenario de notables acontecimientos históricos; una mirada a los hechos transcurridos en Cuba así lo corrobora. Tras la culminación del dominio español en la isla en 1898 debido a la intervención norteamericana, se inicia una etapa que paradójicamente llegó teñida tanto de satisfacción como de frustración para los cubanos. Después de largos años de lucha por obtener su independencia, la República se inaugura en 1902. El escritor y antropólogo cubano Fernando Ortiz la definió como “cacocracia” debido a la sucesión de gobiernos corruptos y la entrega a los intereses extranjeros. Neo-colonia, o falseada República, son los calificativos que habitualmente identifican este período que transcurre dejando un sabor agridulce en la enmienda constitucional Platt, la cual garantizaba la intervención militar del gobierno norteamericano en la isla.

La literatura republicana, especialmente la dedicada a niños y jóvenes, ofrece constancia de la insistencia en la autonomía política y cultural, así como un afán por sensibilizar al lector con los avatares sociales del período. El pájaro de lata (1944) de Anita Arroyo, Cuentos de Apolo (1947) de Hilda Perera y Cuentos de todas las noches (1950) de Emilio Bacardí son ejemplos de libros publicados durante la República que 
contribuyen al desarrollo de la identidad cultural. Por su posición en la cronología histórica y por su limitada producción, a la literatura infantil de esta época se le ha rotulado erróneamente como indigna de estudios críticos, carente de valor ético, estilístico y literario. Las obras para niños y jóvenes han sido sujetas a la omisión y han permanecido al margen de observaciones analíticas por pertenecer a lo que el crítico cubano Rafael Rojas ha denominado, con acierto, la “edad media”, refiriéndose al período histórico que media entre la etapa colonial y la Revolución de 1959. Su analogía, sin embargo, no se debe a una ausencia de cualidades o valores literarios en las obras de la época, sino a la desventurada coincidencia de anteceder a un período que por su carácter revolucionario se dedicará a erradicar su pasado histórico del imaginario colectivo. En su ensayo “Primera República” Enrico Mario Santí observa que “nuestra percepción negativa de la República, la condena del pasado inmediato, se desprende, claro está, de la ruptura que causó la Revolución castrista, que no sólo condenó y sustituyó a la República, sino que durante cuarenta años no ha cesado de desacreditarla en un esfuerzo por legitimar su poder más allá de cualquier cuestionamiento” (127). Como recurso de validación, la degradación del legado histórico republicano le permite al nuevo gobierno ensalzar sus logros y crear un Hombre Nuevo cuya referencia histórica sea la Revolución y los héroes nacionales elegidos por sus líderes.

De acuerdo con la postura de Alga Marina Elizagaray, "no podemos hablar de una literatura para niños y jóvenes en desarrollo hasta después del triunfo de la Revolución” (130). Si bien es cierto que el crecimiento de la literatura infantil cubana alcanza su punto más álgido en la etapa revolucionaria, tras la creación de concursos que estimulan a los escritores debutantes y a las editoriales que promueven y facilitan la 
publicación y distribución de ejemplares, un retorno a la etapa republicana no sólo permite hallar una literatura infantil en la que destacan las representaciones de una identidad nacional incipiente, el reflejo de tensiones sociales de la época y una corriente discursiva autóctona, sino además un punto de referencia y apoyo para desarrollar un criterio mejor fundamentado y completo sobre la literatura infantil que se desarrollará durante la Revolución.

Por ser Cuba una nación sujeta a la colonización española y luego a la intervención e influencia norteamericanas, la relación entre las prácticas coloniales e imperiales y su literatura infantil permite examinar derroteros que arrojen luz sobre la importancia y la necesidad de crear una identidad nacional. La transición hacia la República en 1902 y posteriormente el triunfo de la Revolución en 1959 repercuten en el acontecer social, y éste a su vez influye en las temáticas y los mensajes que los textos infantiles exponen. Con relación a los patrones que debía seguir toda iniciativa intelectual en la cultura cubana, es importante aludir a la celebración del primer Congreso Nacional de Educación y Cultura en 1971, que a su vez surge como consecuencia del discurso “Palabras a los intelectuales” en 1962. En ese discurso inicial, cuyo supuesto tema central es la libertad para la creación artística, se inscribe el postulado que rige las normas de la producción cultural venidera: “Dentro de la revolución, todo; contra la Revolución, nada”. Siguiendo la misma consigna, en un discurso pronunciado en la clausura del primer Congreso Nacional de Educación y Cultura en 1971, se reafirmará el compromiso que tienen los intelectuales y educadores con la Revolución, cuya preocupación principal son las grandes mayorías del pueblo. En ese discurso se pone mayor énfasis en la disposición que debe tener el campo cultural al promover la participación de las masas, a 
que se creen más programas educacionales infantiles de radio y televisión. El incentivo para la creación y producción viene acompañado, sin embargo, por la aclaración de que el intelectual "para volver a recibir un premio, en concurso nacional o internacional, tiene que ser revolucionario de verdad, escritor de verdad, poeta de verdad, revolucionario de

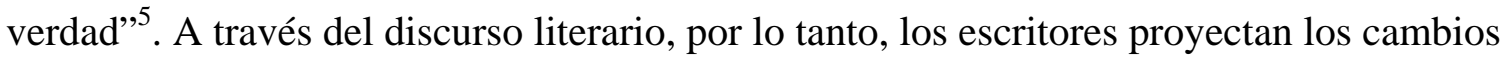
socioculturales mientras abordan con realismo temáticas relacionadas al entorno de los lectores, pero sobre todo, no subvierten los principios establecidos por la Revolución.

\section{Aparato teórico operativo}

La integración del plano ideológico al análisis de la literatura infantil cubana pre y posrevolucionaria arroja luz sobre cómo las condiciones económicas y las estructuras de poder de cada período histórico moldean y afectan las generaciones futuras desde una temprana edad. El nivel ideológico es, de acuerdo a Boris Uspenski, el aspecto más elemental del punto de vista que asume el escritor cuando evalúa el mundo que describe. Cuando hablamos de las ideas que moldean una obra, afirma el filólogo ruso, nos referimos a la estructura a nivel composicional (8). Siguiendo el planteamiento de Uspensky, esta investigación utiliza el punto de vista que adopta el autor, la voz narrativa, o los personajes en una obra determinada para identificar su posición ideológica en cuanto a los cambios sociopolíticos y a la construcción de la nación.

Como ha notado la investigadora literaria Irma Llorens, “desde sus orígenes, la literatura cubana es una parte integral de los procesos sociopolíticos que tienen lugar durante la fase formativa del movimiento nacionalista cubano [...] En el siglo XIX, la

\footnotetext{
${ }^{5}$ Fidel Castro Ruz. "Discurso de clausura del Primer Congreso Nacional de Educación y Cultura”. La Habana, 30 de abril de 1971.
} 
literatura nacional consiste de un conjunto de discursos y prácticas que se proponen fijar y reafirmar la identidad cubana (7). La observación de Llorens se extiende a literatura infantil, especialmente si se cotejan los hechos históricos de la época y las prácticas discursivas del texto. En la narrativa que apela al lector infantil hay un interés por afianzar la identidad cubana, por lo que al contemplar la relación entre obra literaria, entorno y procesos sociales desde un ángulo que incluye las producciones para niños y jóvenes, el marco general se enriquece.

El autor se nutre del acontecer diario y las mismas vicisitudes que afectan su entorno le sirven de inspiración para crear tramas que le presenten al lector infantil una realidad teñida de avatares. El entorno, como apunta Sonia Behar “actúa como elemento transformador en la visión que el intelectual tiene de sí mismo dentro de lo que queda del proceso revolucionario” (43). Según el filósofo húngaro Georg Lukács, para que la vitalidad de las fuerzas del entorno sea captada por el escritor, es preciso que las viva no como abstracciones inertes, sino como realidades concretas (cit. en Navajas 70). El contacto entre escritor y entorno social es ineludible, incluso cuando éste se haya embarcado en la aventura de escribir. Es por eso que en la narrativa infantil cubana, mientras más se distancia de 1959 en un sentido progresivo, y sobre todo en la década del Período Especial, más importancia se atribuye a las preocupaciones sociales, filosóficas y humanas del autor. Estos aspectos validan la aproximación sociológica de Lukács a la literatura, aproximación que según Birger Angvik tiene mucho en común con la teoría de la novela de Mario Vargas Llosa. Para Llosa, indica Angvik, “explicar el texto significa explicarlo desde el punto de vista de las ideas, estado psicológico o antecedentes sociales del autor” (21). En el caso de Cuba, y especialmente en la literatura infantil, explicar el 
texto desde los antecedentes sociales y las ideologías de los escritores permite cuestionar cómo repercuten y se perfilan los cambios sociopolíticos de la Cuba posrevolucionaria en las temáticas y las dimensiones discursivas en la literatura para niños y jóvenes.

\section{Estructura}

En los distintos períodos de la literatura infantil cubana, el contexto histórico ha sido determinante en la relación entre el entorno en que viven y se desarrollan los escritores y sus creaciones literarias. Por lo que al abordar cada época, es preciso tener una clara visión de conjunto. Este estudio propone una periodización que parta de 1899 con la publicación de La Edad de Oro de José Martí, después pasa a la etapa de la República (1902-1958) para luego explorar los primeros treinta años de la Revolución (1959-1989) y finalmente arribar a un estado más actual de la narrativa infantil de 1990 hasta la primera década del siglo XXI. Partiendo de un marco de referencia multidisciplinario en el que se integren discurso, sociedad e identidad nacional, este estudio explora cómo los aspectos sociales han influido en las dimensiones discursivas de la ideología en las producciones infantiles antes y después del triunfo de la Revolución.

La publicación de La Edad de Oro de José Martí en 1899 supone un momento cumbre para la literatura infantil nacional, en el que se fusionan lo nacional y lo universal mediante una instrucción que se ajusta al postulado aristotélico de enseñar deleitando. La tesis que Jorge Mañach elabora sobre la historia y la literatura cubanas en sus discursos “La nación y su formación” y “El estilo en Cuba” sustentan el enfoque analítico de los principios sobre la nacionalidad y complementan los fundamentos martianos con relación a su proyecto para edificar la nación. Esta obra del apóstol, representativa de la literatura infantil decimonónica por su valor literario y estético es un referente para las sucesivas 
generaciones de escritores infantiles latinoamericanos y continúa ocupando un destacado lugar dentro del género en la actualidad. Como revista dedicada a todos los niños de América, la obra de Martí irrumpe en la limitada producción previa, caracterizada por un afán didáctico y un implacable tono moralizante. Esta obra de riqueza y diversidad temática se ha llevado a cabo con rigurosa seriedad y respeto hacia sus receptores. Partiendo de los postulados de José Martí en su ideario independentista y en su ensayo "Nuestra América”, las corrientes ética, artística y autóctona en el discurso martiano, así como los recursos retóricos que emplea para la construcción de una identidad nacional son objeto de análisis en el capítulo uno.

El segundo capítulo se dedica a la República y tiene el objetivo de analizar cómo mediante la crítica implícita en la obra, la narrativa infantil proyecta la realidad social imperante. De acuerdo con las teorías de Wolfgang Iser en The Implied Reader, el concepto de lector implícito plantea un enfoque crítico más dirigido al acercamiento del lector a la realidad literaria presentada por el escritor y "tiene que ver principalmente con la forma de una obra, en la medida que entendamos por forma, básicamente un medio de comunicación o un intercambio de intuiciones” (57). Este capítulo explora cómo los elementos constitutivos de varias obras infantiles tienen el propósito de resaltar lo autóctono y fomentar el arraigo a la patria en resistencia a la imposición extranjera, teniendo en cuenta el poder hegemónico que ejerce Estados Unidos en la isla tras la intervención en 1898. La realidad literaria que presentan los autores, acerca al lector implícito a la realidad social y política en un intento por comunicarle los valores más raigales que contribuyen a representar y edificar la nación, las futuras generaciones. Así, Pelusín y los pájaros (1956) y Pelusín frutero (1957) de Dora Alonso, El pájaro de lata 
(1944) de Anita Arroyo, Cuentos de Apolo (1947) de Hila Perera y Cuentos de todas las noches (1950) de Emilio Bacardí son sujetos a una interpretación crítica que favorece la formación de una conciencia nacional cubana en el imaginario colectivo y que expone la relación entre los eventos socio-históricos y las temáticas tratadas en las producciones infantiles. Se argumenta que más allá de reflejar la lucha contra la tiranía derrocada y la crisis de ciertos valores individuales, la literatura infantil de la época es muestra de un paralelismo poético entre el proceso de la Cuba que se forjaba como nación y la situación del perceptor infantil que nace con cada nueva generación, en una común construcción de identidades.

El tercer capítulo abarca desde 1959-1989 y se enfoca en la producción literaria más relevante dentro de la primera etapa de la revolución. Desde el comienzo del período revolucionario, se enfatiza la ideología como herramienta pedagógica. Dado énfasis crea una notable distinción entre la producción para los más pequeños, antes y después de 1959. A partir de este momento se inicia "la evolución de un movimiento literario que progresivamente haría olvidar las estrictas cartillas pedagógicas al ritmo de los versos y estrofas de sus textos artísticos, no sin salvar las vicisitudes y etapas diversas a las que tuvieron que hacer frente, dadas las peculiaridades históricas a las que se vería abocado el pueblo cubano” (Quiles Cabrera 217). Es necesario retomar el discurso que Fidel Castro dirige a los intelectuales como conclusión de las reuniones con ellos sostenidas en $1961^{6}$ para lograr un mejor entendimiento de las regulaciones a las que debían adscribirse los

\footnotetext{
${ }^{6}$ En 1961, solo dos años después de haber triunfado la Revolución, Fidel Castro pronunció un discurso que se ha quedado para la historia con el título de: "Palabras a los intelectuales". La intervención del comandante arroja luz sobre la urgencia de su respuesta: "El problema que aquí se ha estado discutiendo y vamos a abordar, es el problema de la libertad de los escritores y de los artistas para expresarse [...] El punto más polémico de esta discusión es si debe haber o no una absoluta libertad de contenido en la expresión artística”.
} 
intelectuales para continuar publicando dentro de una revolución que sigue el modelo socialista. La consigna “Dentro de la Revolución, todo; contra la Revolución, nada”, alude a lo que se les exige a la intelectualidad. Plantea, además, el problema de la libertad para la creación artística. Este capítulo tiene como finalidad revelar que existe un cambio significativo en cuanto a ideo-temáticas entre los escritores ya consolidados antes de la Revolución y los que se forman dentro de ella. Tras un recorrido por tres décadas de publicaciones infantiles, este capítulo argumenta que los autores pertenecientes a la etapa pre-revolucionaria se adhieren a un contexto moral e instructivo más característico de la literatura infantil tradicional mientras que las generaciones posteriores se distancian de la tradición establecida para crear un universo narrativo en el que abundan las temáticas relacionadas al mundo de los adultos: el divorcio, el exilio, las diferencias generacionales, la marginalidad y los problemas ambientales.

El cuarto capítulo abarca desde 1990 hasta 2010. Las publicaciones posteriores a la caída del campo socialista y al denominado "Período Especial” en Cuba, ofrecen un giro significativo en cuanto a temáticas, estética y propósitos que distan del concepto tradicional de la literatura dedicada a niños y jóvenes. Este período se caracterizó por la crisis económica y conllevó grandes cambios en la sociedad cubana y en su economía. Sus efectos también se extienden al campo literario y a partir de 1990 son otras las problemáticas que exploran los escritores infantiles. Entre los escritores formados dentro de la Revolución existe un especial interés por proyectar aspectos ignorados en la literatura infantil tradicional.

Desde una perspectiva multidisciplinaria que integre discurso y sociedad, esta disertación analiza los textos con relación a los eventos socio-históricos que afectan el 
desarrollo literario en las distintas etapas de la historia de Cuba. Enfatizando las dimensiones discursivas de la ideología, así como la representación y la consolidación de la nación en los textos infantiles, este estudio perfila su tesis: el contexto histórico, en los distintos períodos de la literatura infantil cubana y especialmente a partir de 1959 ha sido determinante en la relación entre el entorno en que viven y se desarrollan los escritores y sus creaciones literarias, convirtiéndose en exponente canalizador de la realidad social. 


\section{CAPÍTULO I}

\section{REPRESENTACIÓN Y CONFORMACIÓN DE LA IDENTIDAD NACIONAL EN LA}

\section{LITERATURA INFANTIL CUBANA: MOLDEANDO AL FUTURO CIUDADANO}

“Queremos que los niños de América sean: hombres que digan lo que piensan, y lo digan bien: hombres elocuentes y sinceros"

José Martí

Aunque el libro infantil es una conquista moderna, los orígenes de esta literatura se remontan a la edad oral del mito. Los cuentos folklóricos, representativos de la cultura del pueblo a través de su sabiduría natural, no sólo son los primeros que el lector atesora, sino que en ellos reside lo esencial para alimentar el espíritu del niño por su fusión de elementos fantásticos y mágicos. De acuerdo con Enrique Pérez Díaz, en el Caribe de habla de inglesa y francesa, en el que una literatura infantil es prácticamente inexistente, las fuentes tradicionales como el folklor, los cuentos de hadas y los mitos continúan manifestándose en la escritura dedicada a los niños ${ }^{7}$. Sin embargo, es significativo el desarrollo que la literatura infantil del siglo XX alcanza en países como Brasil, Argentina, Venezuela y Cuba, según señala el escritor y crítico cubano.

Cuando en el siglo XVI se introduce en América la imprenta y se comienzan a publicar obras destinadas al desarrollo de la educación, el protagonismo del libro gira en torno a su función como auxiliar pedagógico en el aprendizaje escolar. La literatura

\footnotetext{
${ }^{7}$ Pérez Díaz, Enrique. “Central and South America and the Caribbean”. International Companion Encyclopedia of Children’s Literature. Ed Peter Hunt and Sheila Ray. London: Routledge, 1996. 883
} 
infantil de carácter recreativo es antecedida por una etapa de marcado matiz pedagógico en la cual el mensaje debe ser directo, con un fundamento explícito ${ }^{8}$.

Por su función edificante en la literatura infantil, la fábula cobra vital importancia durante el neoclasicismo. Estas narraciones cortas, en prosa o verso, con una moraleja y personajes no humanos por lo general, se caracterizan por el didacticismo y el humorismo ${ }^{9}$. En el caso de la literatura cubana, el humor prevalece y se acentúa en la fábula. Las primeras narraciones con animales y vegetales cubanos, distintos de los modelos españoles de Iriarte y Samaniego, quienes estaban muy en boga a causa de la tendencia didáctica y moralizante, aparecen en el Papel Periódico de La Habana (17901805). En esta etapa destaca la colección de fábulas El filósofo y el búho de José María Heredia, una composición neoclásica. Sobresalen también el autor de artículos de costumbres José María Cárdenas y los fabulistas, Francisco Javier Balmaseda y Plácido; quien cubaniza éste género. Un libro como Fábulas morales (1847) de Francisco Javier Balmaseda tiene el propósito de resaltar la naturaleza patria: los cocodrilos, los cocuyos, las jutías y las palmas. La obra de Balmaseda sobresale por su vigor, amenidad y su sentido del humor:

Entre las garras de un can una cotorra se hallaba, y a un cerdo con negro afán en su socorro llamaba.

\footnotetext{
${ }^{8}$ Ver Aguinaldo para niños, publicado en La Habana, en 1846 por Juan Guell y Renté y Manuel Costales.

${ }^{9}$ El fabulista Jean de la Fontaine se destaca dentro del género como uno de los más insignes. La publicación de sus Contes (1664) y Fables (1668) le aseguran la fama y el reconocimiento.
} 
Él la vio y dijo: “-¡Infeliz!

la vida te salvaré.....

mas antes me engulliré

esta ración de maíz.

Señora Cotorra, aguarde...”

Ella entonces medio loca

gritó del can en la boca:

“-No venga, porque ya es tarde”. (103)

A principios del siglo XIX surgen los primeros libros destinados específicamente a los niños: textos para la lectura escolar, silabarios y catecismos, cuya estricta función pedagógica continúa imperando (Pérez Díaz 887). A partir de la primera mitad de la centuria la educación comienza a desarrollarse en función de los intereses de las naciones por su independencia. Promover instrumentos que propiciaran una educación desde todos y para todos era objeto de la gestión educativa y formadora. En la segunda mitad del siglo, las publicaciones periódicas dedicadas a los niños comienzan a ser más frecuentes. Mediante estas publicaciones, los artículos didácticos, los poemas y las narraciones se difunden. Como exponentes decimonónicos, vale la pena hacer referencia a Lectura de Pascuas (1899) de Esteban Borrego Echeverría, Libro de lecturas para niños de Manuel Costales y El librito de cuentos y las conversaciones de Cirilo Villaverde (1847). Félix Varela publica Cartas a Elpidio- sobre la Impiedad, la Superstición y el Fanatismo en sus Relaciones con la Sociedad cincuenta y cuatro años antes que La Edad de Oro de José Martí. Emilia Gallega Alfonso considera esta obra un antecedente imprescindible de la martiana ya que se anticipa a lo que será una variante del discurso de 
Martí: “En Cuba, Félix Varela fue el primero en alertar y combatir los peligros que corren tanto la religión como la política cuando caen en manos de los impíos y supersticiosos” (26). Ambas obras, escritas desde el exilio, se asemejan también por su oposición a la ignorancia, a lo despótico y a la privación de libertad.

En la literatura infantil cubana e hispanoamericana, José Martí sobresale desde el punto de vista constitutivo como notable precursor. Como el resto de la obra martiana, $L a$ Edad de Oro se destaca por sus valores morales, éticos y educativos, y no menguan los artículos críticos que desde diversas posturas y disciplinas reiteren los componentes distintivos y meritorios de este hito literario. Sin afán de redundar en la atipicidad y originalidad de esta obra, este capítulo examina la dimensión ideológica a partir de tensiones discursivas entre la producción literaria y la representación y construcción de la identidad nacional.

\section{Ideología y formación ética del hombre ideal en La Edad de Oro de José Martí}

La Edad de Oro se considera pionera en la historia de la literatura infantil hispanoamericana, estableciendo un antes y un después desde su publicación. Cada período histórico en la historia de Cuba ha traído un punto de inflexión y durante la transición de la Colonia a la República el punto de quiebre en la literatura infantil nacional, lo marca La Edad de Oro. Aunque otras publicaciones de origen nacional e internacional la anteceden, no aspiran a su ideal estético y contextual. Mucho se ha resaltado el aspecto innovador que la caracteriza y sitúa como obra fundacional, distante en estética y contenido de las precedentes. Concebida como una revista mensual de recreo para los niños de América, La Edad de Oro contaba con bellos grabados e ilustraciones. Cuentos, ensayos y poesías, así como una sección final titulada “La última 
página” integran la revista de la que sólo se publicaron cuatro números durante los meses de julio a octubre de 1889, en la ciudad de Nueva York. Publicada en formato de libro a partir de 1905, la revista ha pasado a formar parte del canon literario cubano y latinoamericano.

Su subtítulo "Publicación mensual de recreo e instrucción dedicada a los niños de América”, muy similar al de la más famosa revista infantil francesa de entonces (Magasin d' Education et Récréation) expone explícitamente quién es su destinario y cuál es su objetivo. La revista se concibe con el propósito de inculcarle al niño hispanoamericano conocimientos referentes a la historia, el arte, la literatura y la ciencia, resaltando a su vez la apreciación de la patria y los valores nacionales. Al igual que Horacio (delectare et docere), Martí cree en el deseable efecto formativo y moral de la obra y considera que debe instruir pero también entretener. De tal manera, en cada número la instrucción explícita para niños y niñas es agradablemente introducida como una cucharada de jarabe en la que se ha añadido la medicina: "Los temas escogidos serán siempre tales que por mucha doctrina que lleven en sí, no parezca que la llevan, ni alarmen al lector de pocos años con el título científico ni con el lenguaje aparatoso”(1).

En los tres primeros números aparece una historia de trasfondo nacional: “Tres héroes”, “Las ruinas indias” y “El Padre Las Casas” y una o más con matiz universal: “La Ilíada”, “Músicos, poetas y pintores” y “La exposición de París”. Sólo el cuarto número se aparta de ese patrón ya que todos los cuentos publicados en él tienen temáticas ajenas a la historia del continente americano. Con relación a la selección de temas en esta obra infantil, el escritor y crítico cubano Antonio Orlando Rodríguez observa que: 
Martí propone artículos acerca de temas inusitados para la época (como la grandeza de las culturas prehispánicas, la lucha contra el colonialismo o los progresos de la ciencia y la tecnología) y entrega, además, traducciones o rescrituras de narraciones de Laboulaye y de Anderson, versiones de poemas de Helen Hunt Jackson y de Emerson, su antológico cuento en versos "Los zapaticos de rosa”, y relatos originales, como “Nené traviesa”, “Bebé y el señor Don Pomposo” y “La muñeca negra” en los que retrata personajes infantiles de inusual densidad psicológica. 67 Mediante la inclusión de varios cuentos extranjeros, Martí da a conocer la literatura universal. Sin olvidar las raíces hispanoamericanas logra establecer un equilibrio mediante el cual incluye otros textos de su autoría y, aun cuando habla de héroes ajenos, siempre establece un vínculo entre el paisaje y la historia foráneos con la propia, y le ofrece al niño una cultura ecuménica. La estructura de sus cuentos se adscribe a otro de los presupuestos que plantea Horacio en su Arte poética: conservar la simplicidad y la unidad del texto. Martí especifica en la contraportada de la revista: "Cada número contiene, en lectura que interesa como un cuento, artículos que son verdaderos resúmenes de ciencias, artes, historia y literatura, junto con artículos de viajes, biografías, descripciones de juegos y de costumbres, fábulas y versos”.

En el ideario martiano es notable un afán por fundar la nación mediante la formación de los niños. La finalidad de la obra, ejemplar en su objetivo de moldear y educar, es análoga a la intención de formar la nación desde la edad más temprana. María Gracia Pardo observa que debido a estas pretensiones modélicas "la infancia no sería entendida como una etapa lúdica, sino como una de 'piedra bruta' en espera de escultor” 
(6). En Martí hay dos intensiones en este sentido: quiere ser amigo, pero también escultor, educador que se propone formar ética y moralmente a los niños de América, siendo esta etapa de formación idónea para moldear la generación futura.

La Edad de Oro adopta dos elementos de la pedagogía oficial: la educación del hombre íntegro, del ciudadano y, la naturaleza del educado y la psicología de la niñez ${ }^{10}$. Para construir una República de todos y para el bien de todos como ambicionaba Martí es fundamental emprender la formación ciudadana desde la infancia. En una carta íntima a su amigo Manuel Mercado su seriedad y compromiso, así lo corroboran:

Los que esperaban, con la inexcusable malignidad del hombre, verme por esta tentativa infantil, por debajo de lo que se creían obligados a ver en mí, han venido a decirme, con su sorpresa más que con sus palabras, que se puede publicar un periódico de niños sin caer de la majestad a que ha de procurar alzarse todo hombre (146)

\section{Tensiones discursivas: Intención y Cumplimiento}

Al prologar La Edad de Oro, Martí le extiende una invitación al lector para que envíe a la revista sus inquietudes. Aunque en latín la palabra infantia significa literalmente "mudez", como sujeto social el niño precisa del afecto y la inteligencia de un adulto para alcanzar una conciencia cívica y un desarrollo humano integral. De manera que para estimular la socialización e integración del niño es preciso propiciar el diálogo entre adulto y menor. Martí estimula el ansia de conocer de lector niño y lo invita a compartir sus preguntas, sin importar sus limitaciones ortográficas:

\footnotetext{
${ }^{10}$ Benjamin, Walter. La literatura infantil, los niños y los jóvenes. Buenos Aires: Nueva Visión, 1989.
} 
Cuando un niño quiera saber algo que no esté en La Edad de Oro, escríbanos como si nos hubiera conocido siempre, que nosotros le contestaremos. No importa que la carta venga con falta de ortografías. Lo que importa es que el niño quiera saber. Y si la carta está bien escrita, la publicaremos en nuestro correo con la firma al pie, para que se sepa que es niño que vale. (2)

La invitación que extiende Martí al niño produce un intercambio significativo si tomamos en cuenta la mudez a la que se asocia tradicionalmente la niñez durante esta época. Al sujeto silente se le reconoce el derecho de hablar y se le sugiere cómo hacerlo. En la literatura infantil que se propone escribir Martí afloran los primeros intentos de “una literatura para niños que busca o propicia, de diversas formas, el diálogo, la participación activa de los niños en el mundo” (Goldin 10). Al culminar cada número, Martí reitera que: "Estas últimas páginas serán como el cuarto de confianza de La Edad de Oro, donde conversaremos como si estuviéramos en familia” (52). En un intento por disipar la distancia entre escritor y lector, entre adulto y niño, comienza a abrirse el camino hacia una literatura que María Gracia Pardo considera "basada en el respeto por la voz del niño”. Sin embargo, una mirada atenta al sistema de ideas que moldea La Edad de Oro permite apreciar el discurso martiano en términos de tensiones. Vale la pena explorar hasta qué punto se logra establecer un diálogo frente a una estructura discursiva en la que predominan la estructura de monólogo y el punto de vista ideológico del autor.

Cuando Martí sugiere a sus lectores que acrecienten su acervo literario, su afán modélico destaca sobre su tono amistoso: "El que tenga penas, lea las Vidas Paralelas de Plutarco, que dan deseos de ser como aquellos hombres de antes, y mejor, porque ahora 
la tierra ha vivido más, y se puede ser hombre de más amor y delicadeza” (51). En su sugerencia, el autor contrapone la fuerza física al conocimiento y con cierto matiz que alude al discurso del Siglo de Oro enfatiza que la fuerza está en el saber y no en los puños: “es bueno ser fuerte de cuerpo; pero para lo demás de la vida, la fuerza está en saber mucho” (52). La evaluación ideológica a nivel discursivo, en este caso, se realiza desde una perspectiva única, dominante ${ }^{11}$. La invitación que hace el escritor, no obstante es innovadora no sólo porque desde el punto de vista de género les da participación a las niñas también, sino porque reconoce el concepto de lector implícito ${ }^{12}$. Aunque predominan las intenciones pedagógicas, existe una diferencia entre la obra de Martí y la literatura didáctica de la época. Esta diferencia reside en el respeto que siente el escritor por los niños y la relación de amigo/narrador que fomenta con su lector implícito. Hernández-Miyares nota que "no se percibe aniñamiento alguno, ni tampoco presunción de estilo” (17). Martí comprende que se necesita de un interlocutor para desarrollar su proyecto e inculcar en el futuro ciudadano sus presupuestos ideo-estéticos, por lo que revelando la intención del texto se propone crear un lector virtual.

De acuerdo con la estética de la polifonía propuesta por Mijaíl Bajtín, para que llegue a existir la significación es preciso el contacto de voces a nivel textual, la respuesta de un oyente a un hablante, la inscripción del discurso en una pragmática comunicativa. ${ }^{13}$

\footnotetext{
${ }^{11}$ En términos de Bajtín, éste es un ejemplo de la estructura de monólogo. Bajtín, Mijail. Problemas de la poética de Dostoievski. Buenos Aires-México: FDC, 2012.

${ }^{12}$ En The Implied Reader, Wolfgang Iser lo define como un método crítico que "tiene que ver principalmente con la forma de una obra, en la medida que entendamos por forma, básicamente un medio de comunicación o un intercambio de intuiciones” (57)

${ }^{13}$ En términos de Bajtín, éste es un ejemplo de la estructura de monólogo. Bajtín, Mijail. Problemas de la poética de Dostoievski. Buenos Aires-México: FDC, 2012.
} 
En el discurso martiano de La Edad de Oro existe una tensión entre la invitación al diálogo mediante el tono amistoso y el establecimiento de perspectivas ideológicas dominantes. Utilizando el texto como espacio para la intercepción lingüística y la concepción del “yo” como esencialmente social, Martí tiene la intención de avalar un sentido de horizontalidad entre lector y escritor:

Este periódico se publica para conversar una vez al mes, como buenos amigos, con los caballeros de mañana, y con las madres de mañana, para contarles a las niñas cuentos lindos con qué entretener a sus visitas y jugar con sus muñecas; y para decirles a los niños lo que deben saber para ser de verdad hombres. Todo lo que quieran saber les vamos a decir, y de modo que lo entiendan bien, con palabras claras y láminas finas. Les vamos a decir cómo está hecho el mundo: les vamos a contar todo lo que han hecho los hombres hasta ahora. (1)

Aunque es explícita su finalidad de "conversar" mensualmente, el tono del escritor no deja de ser prescriptivo. Martí preceptúa “lo que deben saber” los niños en su proceso de formación. A los lectores se les va a decir “cómo está hecho el mundo” y “todo lo que han hecho los hombres hasta ahora”, pero ¿desde la perspectiva de quién? ¿Se validará la voz del conquistado o del conquistador al narrar la historia, o acaso ambas? La selección de temas complejos, que a pesar de la intención explícita que tiene el escritor de tratarlos con la mayor claridad posible pueden dificultar la comprensión por parte del lector, estimula al niño a plantearles interrogantes a padres y maestros. Desde esta perspectiva y combinando la seriedad intelectual de la empresa martiana con una de sus intenciones primarias se promueve el diálogo entre niño y adulto mediante el intercambio y el tratamiento de aspectos que enriquezcan el acervo intelectual y cultural del lector. 
En “Tres héroes”, el escritor ofrece una resumida biografía sobre tres grandes figuras libertadoras del continente: Simón Bolívar, el cura Hidalgo y José de San Martín. Un breve recuento histórico sobre las hazañas llevadas a cabo por el trío informa al lector sobre la valentía y grandeza de valores de los héroes hispanoamericanos. La voz narrativa comienza relatando la sensación que le produce a un viajero (el propio Martí) encontrarse frente a la estatua de Bolívar y este encuentro le sirve de excusa para exponer sus ideas sobre los valores patrióticos, la honradez y la libertad. A partir de este planteamiento se desarrollan las hazañas y méritos de lo que se podría denominar tres hombres sagrados. Para exponer las cualidades morales y la valentía de Bolívar, Hidalgo y San Martín, el narrador primero realiza un retrato físico seguido de un retrato moral conforme al modelo establecido en vísperas del Siglo de Oro español por Claros varones de Castilla de Fernando del Pulgar, después realza los méritos de cada uno en las luchas que libraron y finalmente relata de forma muy breve cómo murieron. El texto culmina exponiendo, a modo de resumen, la visión martiana acerca de la libertad de los pueblos y de los rasgos distintivos que caracterizan a los héroes. Destacan figuras retóricas como la anáfora mediante la repetición de ‘cuentan que’ y ‘un hombre que’ y en el plano ideológico, el punto de vista a través del cual se perfila la honradez del hombre es el martiano: “Cuando hay muchos hombres sin decoro, hay siempre otros que tienen en sí el decoro de muchos hombres” (Martí 5). En la claridad de ideas y la sencillez de estilo de la prosa martiana hay un predominio del tono moral y de los rasgos ideologizantes:

Libertad es el derecho que todo hombre tiene a ser honrado, y a pensar y a hablar sin hipocresía. En América no se podía ser honrado, ni pensar, ni hablar. Un hombre que oculta lo que piensa, o no se atreve a decir lo que 
piensa, no es un hombre honrado. Un hombre que obedece a un mal gobierno, sin trabajar para que el gobierno sea bueno, no es un hombre honrado. Un hombre que se conforma con obedecer a leyes injustas, y permite que pisen el país en que nacieron los hombres que lo maltratan, no es un hombre honrado. (4)

En varias ocasiones se alude a la figura paterna y a la relación padre e hijo. Al describir la reacción del viajero frente a la estatua de Bolívar notamos la alusión: “lloraba frente a la estatua, que parecía que se movía, como un padre como cuando se le acerca a un hijo” (4). Finalizando el texto hay otro caso muy representativo de esta relación: “Quisieron algunas veces lo que no debían querer; pero ¿qué no le perdonaría un hijo a su padre?” (8). Es decir, que la concepción lector niño y lector adulto, padre e hijo puede asumir varias lecturas y acepciones. En algunos casos se refiere a la relación literal padrehijo, en otras la figura paterna es proyectada por el libertador/héroe y por el autor/narrador. Martí incorpora y entrelaza con sutileza el vínculo entre complejidad lingüística y conceptual, el lector adulto y la figura paterna. En "Irresistible romance: the foundational fictions of Latin America” Doris Sommer afirma que “José Martí was another notable propagandist for the nation building novel. America needed and edifying and practical literature” (77). Añade además y, muy en consonancia con el caso de Martí que "many writers dedicated themselves to reform through education” (74). Para el escritor de La Edad de Oro la construcción de la nación a partir de la obra literaria no sólo debe acometerse desde una postura de autor, sino de figura paternal que reforma y educa. Martí es un perfecto ejemplo de la observación de Sommer ya que La Edad de Oro es parte de ese conjunto de textos que aspira a establecer una nación moderna en la que se 
proyecte la visión ideal del escritor, la conexión entre la prosa y el proyecto nacional: "Stablishing modern nations and projecting their ideal histories through the novel” (73). El ideario martiano hace referencia a la libertad política, social y cultural de América, en un afán de resaltar los atributos de la cultura americana así como de los grandes hombres de estas naciones. Quiere el escritor que sus ideales sobre el valor, el patriotismo y el orgullo nacional sean compartidos por las generaciones en formación así como por los adultos encargados de instruir y educar a esas generaciones por lo cual el lector adulto es también su destinatario. Martí es revolucionario en el sentido de que protesta ante lo que acontecía en América con relación a la libertad de expresión y a la imposibilidad de ser un hombre honrado, pero también lo es al brindarle al lector infantil la oportunidad de familiarizarse con escenas y costumbres de las culturas ancestrales y con significativas figuras históricas. Tres Héroes es uno de los textos en que resaltan los matices ideológicos, así como la tensión entre un intento de acercamiento amistoso y el predominio de una voz dominante que refleja las pretensiones modélicas.

La enseñanza de la moral es fomentada durante la infancia porque se le considera necesaria. De acuerdo con el teórico social italiano Antonio Gramsci, no se puede separar nunca al hombre que hace del hombre que piensa, así la unidad de pensamiento y acción forma lo que él denomina praxis. En Martí la palabra es un recurso que le ofrece al lector una perspectiva de la historia, de manera que en el discurso la voz ideológica aspira a moldear y a construir. Martí exhorta a los hombres de los pueblos de América a tomar acción, a luchar por la democracia. El hombre debe tomar acción, hablar y pensar sin hipocresía. Decir la palabra es transformar la realidad, educar los criterios de una persona, en este caso del lector. 
El autor concibe su lector implícito y lo invita a la lectura, se manifiesta dentro del alcance perceptivo del niño lector. De esta manera el niño encuentra dentro del texto a un narrador que maneja su mismo lenguaje y con quien puede entablar una amistad, lo cual facilita que se sienta deseoso de entregarse y dejarse llevar por las experiencias y enseñanzas que se le ofrecen. Según expresa Aidan Chambers “cuando un autor establece una alianza y maneja un punto de vista que atrapa al niño, puede manipular esa alianza como recurso para guiar al lector hacia los significados que pretende revelar” (104).

Los autores, conscientemente o no, revelan en su narrativa lo que quieren de sus lectores, el tipo de relación que están buscando establecer con ellos. Iser plantea que las manipulaciones que el autor hace de las alianzas y los deseos de los lectores conducen a la conversión ulterior del lector implícito en lector implicado: entregado al libro, a su trama y personajes (47). El lector empieza a participar en la creación del libro y cobra conciencia de los “espacios para la interpretación”, es decir, los que el autor deja para que lo complete. Daniel Goldin nota, por ejemplo, la importancia que tiene la literatura infantil en la que el diálogo entre adulto-niño asigne a ambos el mismo nivel ontológico: Nada hay más aburrido que un adulto que desdeñe a los niños, ni más bobo que un adulto que supone que el diálogo con ellos implica plegarse a su nivel intelectual o de discurso. Si en nuestro tiempo la literatura para niños es una esperanza es porque, como ninguna otra creación cultural, se presta a propiciar un replanteamiento de la relación adulto-niño que mutuamente nos invente (19). Martí se asegura de inventar e invitar a sus lectores a dialogar, de considerar su capacidad intelectual. Emprende una tarea de semejante envergadura con la convicción de que su pedagogía inicia un intercambio amistoso y familiar que derriba la concepción 
tradicional en la que el niño es inferior al adulto: "el estilo del escritor revela sus suposiciones respecto a la capacidad del lector implícito para manejar su lenguaje y sintaxis” (Chambers 105). En el relato "La muñeca negra”, publicado en el cuarto número, Martí enfatiza sus creencias en la igualdad racial y sutilmente critica la indolencia y el olvido de la burguesía ante los marginados. Piedad, niña blanca de notable belleza, espera el día de su octavo cumpleaños en compañía de su muñeca negra, Leonor. La presencia de criados, posiblemente de color, el cocinero, lavanderas, la modista y las cintas francesas entre otros, indican la posición burguesa de Pilar. Sus padres le obsequian a Pilar una nueva muñeca de porcelana el día de su cumpleaños. Con la excusa de que tiene sueño, Piedad se retira a su cuarto después de jugar un poco con la muñeca nueva. Es con Leonor, la muñeca negra que le expresa cariño con la mirada, con quien Piedad quiere jugar. Las características físicas de Leonor (negra, fea y con poco pelo) contrastan con las de la nueva muñeca (rubia, de porcelana y ojos azules) y es indicativo de las construcciones raciales de la época. Mediante el contraste físico entre las muñecas se perfila un dominio hegemónico del blanco sobre el negro. El elemento racial se sugiere sutil pero inequívocamente en el símbolo de la muñeca negra. El nombre que elige Martí para su protagonista, Piedad, simboliza la compasión que siente el sujeto “superior” por el “inferior”. Ann González señala que contrario al mensaje que el escritor intenta transmitir, subyacen actitudes coloniales ya que la blancura y belleza del cabello rubio y los ojos azules de la protagonista contrastan con la fealdad de Leonor. La preferencia que muestra Piedad hacia Leonor denota compasión, siendo la lástima lo que implica una ventaja sobre el otro. Piedad asume una posición soberbia al dirigirse a su criada: 
“¡¡Pero, criada, llévame pronto!” (187). El tono que asume la niña al dirigirse a la empleada doméstica denota, además, el cambio de actitud que puede haber en un niño y que refleja su falta de inocencia y su capacidad de manipular el entorno para conseguir su finalidad (en el caso de Piedad quiere regresar a su cuarto para estar con su muñeca negra). Piedad está muy consciente de su superioridad con relación a la sirvienta y aunque el narrador intenta transmitir un mensaje de aceptación hacia el menos afortunado, ya sea por su estatus social o sus atributos físicos, la irreverencia del personaje principal en esa instancia es reflejo de la imposibilidad de alcanzar ese ideal de igualdad.

Al referirse al estilo que Martí utiliza al escribir para los niños, Fina García Marruz afirma que "lejos de decirles cosas infantiles con un lenguaje de adulto, les copia su pintoresco y gráfico lenguaje para decirles cosas profundas y bellas” (196). En su ensayo "La Edad de Oro”, Marruz expresa que "hay muchos pasajes que los niños no entienden del todo” (195). Existe un interés por brindarles a los lectores una literatura digna del intercambio adulto-niño, sin embargo, al desarrollar temáticas como la lucha de los pueblos sojuzgados contra el colonialismo o la desmitificación sutil de la caridad burguesa, la complejidad ideo-estética contrasta con la intención predominante de familiarizar al lector infantil en una primera instancia con hechos significativos. Martí se muestra así consecuente con su precepto de que "los temas escogidos serán siempre tales que por mucha doctrina que lleven en sí, no parezca que la llevan” ( ).

En “Bebé y el señor Don Pomposo" aparece otro contraste significativo entre dos niños con características físicas y posiciones sociales muy diferentes. Martí ofrece una descripción de Bebé bastante similar a la de Piedad: "Bebé es un niño magnífico, de cinco 
años. Tiene el pelo muy rubio, que le cae en rizos por la espalda” (49). Su primo Raúl, sin embargo, es huérfano y con rasgos muy opuestos a los de Bebé: “no tiene el pelo rubio, ni va vestido de duquesito, ni lleva medias de seda coloradas” (50). El ideal de belleza por el que se rige Martí es el occidental: piel blanca, ojos azules y cabellos rubios. Aunque la función ideológica de su discurso es formar los futuros hombres de América con una consciencia de igualdad de clases y valores patrios, Martí nos recuerda que el ideal de belleza es aquél que atribuye a Piedad y a Bebé. Un rastro de racismo colonial implica que el lector implícito es Piedad, es Bebé; no la muñeca negra, no Raúl.

\section{Aquel maestro de La Edad de Oro: Rasgos pedagógicos}

Es importante reflexionar sobre el aspecto pedagógico que se desprende de $L a$ Edad de Oro dada su función de representar y formar la nación. Los hechos históricos, las figuras y obras literarias que nutren el texto son reflejo de una perspectiva global. Al moldear los hombres y mujeres de una nación incipiente, Martí les brinda una formación en la que se funden los valores nacionales con los universales. Resulta importante cotejar las similitudes entre el quehacer martiano y los presupuestos de otro destacado educador: Paulo Freire. A pesar de la distancia geográfica y temporal que los separa, las perspectivas de ambos intelectuales sobre la función del educador y en particular, la participación activa, son semejantes. Para el brasileño, ubicado ya en su contexto existencialista, “el hombre es un ser de búsqueda permanente” (20). La búsqueda implica un sujeto, un punto de partida y un objetivo. La figura de Martí simboliza también ese hombre de búsqueda incesante, que no se conforma con que los hombres de América no puedan expresar sus ideas, tener decoro y valores patrios. El punto de partida de Martí es dirigirse a los niños hispanoamericanos y su objetivo es que sepan cómo "se vivía antes y 
se vive hoy en América y en las demás tierras” (1). En Martí se halla el ímpetu por develar los grandes acontecimientos históricos, por resaltar la grandeza de ciertas culturas y por moldear las mentes en desarrollo desde una postura ética y moralizante. Freire, similarmente, observa que el educador es como una olla en la cual se depositan conocimientos como si el conocer fuera el resultado de un acto pasivo, y se adelanta a su tiempo al atribuirle valor al aprendizaje activo. Cuando se publica Sobre la acción cultural (1971), Freire ha comprendido que el acto pasivo es una falsa concepción de la educación. Freire y Martí son partidarios del diálogo entre estudiantes y maestros, de lo que Freire llama “pedagogía de la liberación”. Para el promotor brasileño de la educación el tema principal del "tercer mundo" es la conquista del derecho de expresión de los ciudadanos. Asevera Martí que el hombre ha de decir lo que piensa y tener pensamiento propio para que América pueda ser libre. Jean Paul Sartre expresa que la conciencia sólo es vacía en la medida misma en que no está llena de mundo ( ). Martí quiere llenar de mundo y de historia las conciencias de sus lectores, transmitirles valores y enseñanzas que enriquezcan su acervo cultural e intelectual y lo hace desde su punto de vista ideológico.

En “Las ruinas indias” resalta el impulso anti-hegemónico. En este relato la cultura y la historia del continente americano son ejes centrales del discurso. Con un contenido centrado en el imperio azteca, el relato comienza presentado el tema: "De México trataremos hoy” (83). Desde el inicio, el narrador atribuye cualidades positivas a la cultura precolombina condicionando e inclinando al lector a estar de acuerdo con sus ideas: "No se puede leer sin ternura, y sin ver como flores y plumas por el aire, uno de esos buenos libros viejos forrados de pergamino, que hablan de la América de los indios, 
de sus ciudades y de sus fiestas, del mérito de sus artes y de la gracia de sus costumbres” (81). Prosigue el narrador a establecer las tres etapas de desarrollo de lo que María Gracia Pardo ha denominado 'el tropo de la infancia en Latinoamérica'. Es decir, que al referirse a los pueblos de América los clasifica como ‘acabados de nacer’, 'pueblos de más edad’ y 'pueblos ya hechos', en un esquema teleológico que equipara el crecimiento biológico de los niños con la evolución de los pueblos. La representación tripartita que realiza el narrador tiene múltiples connotaciones además de estar relacionada a la metáfora de crecimiento del continente. La analogía de las edades también había estado presente desde Grecia. Hesíodo distingue cinco edades: oro, plata, bronce, héroes y hierro. Las variantes son múltiples pero todas tienen en común la concepción de estadio de felicidad originario que se degrada progresivamente hasta llegar a la infelicidad de los contemporáneos al autor. La Edad de Oro alude a esa primera etapa: la niñez, en este caso, y luego Martí se remite a este esquema para referirse a las etapas de las culturas precolombinas con relación a la conquista. Resulta imposible pasar por alto la semejanza que existe entre esta técnica que utiliza el autor y la usada por el Inca Garcilaso en sus Comentarios reales. Al crear su teoría de las tres edades, Garcilaso expone cómo era la cultura preincaica durante y después de la llegada de los españoles (58). Su condición de mestizo lo convierte en candidato idóneo para presentar ambos lados de la conquista. Usando la misma estructura, Martí realza la América indígena, específicamente la cultura azteca: “Todo lo suyo es interesante, atrevido, nuevo. Fue una raza artística, inteligente y limpia” (81). Las láminas de ese libro de pergamino que al narrador hacen rememorar con simpatía la América precolombina aluden específicamente a México y son el punto de partida para ingeniosamente exponer la vida pre-azteca, la llegada de los españoles y el 
efecto devastador que causaron. De antemano se resalta el conocimiento de esta civilización al contrastarla con las precedentes:

A México lo poblaron primero los toltecas bravos, que seguían, con los escudos de cañas en alto, al capitán que llevaba el escudo con rondelas de oro. Luego los toltecas se dieron al lujo; y vinieron del Norte con fuerza terrible, vestidos de pieles, los chichimecas bárbaros, que se quedaron en el país, y tuvieron reyes de gran sabiduría. Los pueblos libres de los alrededores se juntaron después, con los aztecas astutos a la cabeza, y le ganaron el gobierno a los chichimecas, que vivían ya descuidados y viciosos. (83)

La llegada de los españoles se expone con la introducción de Cortés no sin explícitamente resaltar que "venció a los aztecas con la ayuda de los cien mil guerreros indios que se le fueron uniendo, a su paso por los pueblos oprimidos” (83). Es cierto que la voz narrativa hace mención de la opresión a la que sometían los aztecas a sus pueblos vecinos, pero lo que resalta en la cita es principalmente que el éxito de Cortés se debió en gran medida al desencanto esparcido por el imperio, y a la ayuda de combatientes conocedores del territorio. Se expone de esta forma, uno de los aspectos contribuyentes al éxito del conquistador español. La descripción de cada etapa que realiza el narrador es extensa y detallada. Prosigue a relatar el efecto de la llegada de los peninsulares, no sin enfatizar la valentía de los guerreros: "Las armas de fuego y las armaduras de hierro de los españoles no amedrentaron a los héroes indios, pero ya no querían obedecer a sus héroes el pueblo fanático, que creyó que aquellos eran los soldados del dios Quetzalcoatl que los sacerdotes les anunciaban que volvería del cielo a libertarlos de la tiranía” (84). La 
degradación del imperio se agrava a partir de esta segunda etapa en que el narrador describe más estrategias usadas por el conquistador español para lograr su victoria y como en un lamento exclama: "Y ¡qué hermosa era Tenochtitlán, la ciudad capital de los aztecas, cuando llegó a México Cortés!’(84). La selección del imperfecto para referirse a la ciudad central del imperio alude a un estado idílico anterior que ha desparecido tras una conquista intemperante y avasalladora. Sin sacrificar estilo o contenido la siguiente cita sintetiza a qué ha quedado reducida la grandeza de la civilización azteca:

¡De toda aquella grandeza apenas quedan en el museo unos cuantos vasos de oro, unas piedras como yugo, de obsidiana pulida, y uno que otro anillo labrado! Tenochtitlán no existe. No existe Tulán, la ciudad de la gran feria. No existe Texcoco, el pueblo de los palacios. Los indios de ahora, al pasar por delante de las ruinas, bajan la cabeza, mueven los labios como si dijesen algo y mientras las ruinas no les quedan atrás, no se ponen el sombrero. De ese lado de México, donde vivieron todos esos pueblos de una misma lengua y familia que se fueron ganando el poder por todo el centro de la costa del Pacífico en que estaban los nahuatles, no quedó después de la conquista una ciudad entera, ni un templo entero. (86) Un esfuerzo por transmitir la importancia del pasado prehispánico es notable en la expresión del escritor. Al resaltar la grandeza de lo perdido, el aspecto devastador de la conquista, el autor se identifica con los conquistados.

Martí compara los logros de las culturas mesoamericanas con los de las culturas de la antigüedad clásica: “allí se describen pirámides más grandes que las de Egipto; y hazañas de aquellos gigantes que vencieron a las fieras; y batallas de gigantes y hombres; 
y dioses que pasan por el viento echando semillas de pueblos sobre el mundo” (82). Más adelante realiza otra comparación de esta índole justificando los sacrificios que se hacían en el Nuevo Mundo: “Hay sacrificios de jóvenes hermosas a los dioses invisibles del cielo, lo mismo que los hubo en Grecia, donde era tantos a veces los sacrificios que no fue necesario hacer altar para la nueva ceremonia” (83). Tras esa estratégica comparación reside el propósito de enaltecer las civilizaciones precolombinas. ¿Cómo se podrían acusar de bárbaros y salvajes si practicaron los mismos rituales de sacrificio que los griegos? La analogía, por el contrario, justifica los sacrificios y realza la arquitectura, posicionando ambos aspectos a la altura de otras civilizaciones de semejante trascendencia. Apela además a la comparación de América y Europa en cuanto al tema de los sacrificios: "hubo sacrificios en masa, como los había en la Plaza Mayor, delante de los obispos y del rey, cuando la Inquisición de España quemaba a los hombres vivos, con mucho lujo de leña y de procesión, y veían la quema las señoras madrileñas desde los balcones” (83). La postura de Martí es clara: desaprueba los actos injustos cometidos por los españoles y justifica su posición realzando la superioridad de los vencidos mediante su comparación con las civilizaciones de la antigüedad y denigrando las actitudes, comportamientos y acciones de los vencedores: "Y de los indios han dicho más de lo justo en estas cosas los españoles vencedores, que exageraban o inventaban los defectos de la raza vencida para que la crueldad con que la trataron pareciese justa y conveniente al mundo"(83).

En La Edad de Oro, Martí iguala en un primer acercamiento a los conquistados y los conquistadores. Colocándolos en el mismo nivel de ignorancia y superstición equipara a estas últimas en poder: "la ignorancia es la otra cara de la superstición y ambas 
son la expresión de la barbarie” (57). El escritor subraya que la historia de los conquistados y los conquistadores la escriben los vencedores, de ahí que se difame a la raza vencida. Destaca la virtud de los caídos, para manifestar la conducta sanguinaria y despótica de los conquistadores. Como padre permisivo que resalta con ahínco las cualidades del hijo, en este caso de ese pueblo acabado de nacer, en pañales, al presentar a América en ese estado Martí acentúa la vulnerabilidad de sus pueblos, su proclividad a ser manipulados por estar en un estado de formación, de desarrollo.

¿Acaso no se encuentra el lector niño en el mismo estado de formación? Esta tribu ajena al mundo de los adultos que es la de los niños es ideal para ser colonizada. La enseñanza se convierte en el vehículo ideal para legitimar el respeto incuestionable hacia la historia del continente, para fomentar el respeto a las culturas precolombinas y a la nación. Educar es una práctica social que debe relacionarse históricamente al conocimiento, al poder y a la lucha política y cultural sobre el lenguaje y la experiencia en el otro. Al narrar con un propósito didáctico y educativo el lenguaje se convierte en un instrumento que simultáneamente silencia o exalta las voces de los oprimidos o ausentes: "Language is both: hegemonic and counterhegemonic, instrumental in both silencing the voices of the oppressed and in legitimating oppressive social relations” (Freire 5). La voz narrativa que educa tiene un dominio sobre sobre los lectores, principalmente en el lector niño. El estado de hegemonía cultural según Gramsci se entiende como la dominación y mantenimiento de poder que ejerce una persona para la persuasión de otros sometidos, minoritarios o ambas cosas, imponiendo sus propias creencias e ideologías con el fin de perpetuar un estado de homogeneidad en el pensamiento y en la acción (32). Ese otro sobre quien el escritor ejerce un dominio y a quien le impone sus creencias e ideologías 
es, en este caso el niño, quien pertenece a un grupo minoritario. Sin embargo, Martí está consciente que de no hacerlo él, serán otras influencias nocivas y verdaderamente hegemónicas las que indoctrinen al niño.

Aunque en principio Martí intenta considerar al lector niño como un igual, su posición es predominante y su discurso contiene tendencias y parcialidades. El escritor no sólo relata, sino también selecciona, excluye perspectivas y matiza su discurso de acuerdo a su plano ideológico para contrarrestar la influencia de la hegemonía oficial. Muy simbólica es la selección de nombres que realiza Martí al continuar hablando de todas las maravillas que encontramos sobre la historia de América al leer los viejos libros de pergamino:

Y cuando se lee en los viajes de Le Plongeon loa cuentos de los amores de la princesa maya Ara, que no quiso querer el príncipe Aak porque por el amor de Ara mató a su hermano Chaak; cuando en la historia del indio Ixtlilxochitl se ve vivir, elegantes y ricas, a las ciudades reales de México, a Tenochtitlán y a Texcoco; cuando en la "Recordación Florida del capitán Fuentes, o en las Crónicas de Juarros, o en la Historia del conquistador Bernal Díaz del Castillo, o en los viajes del inglés Tomás Gage” (82) Formando parte de ese porcentaje mínimo que delata los abusos llevados a cabo por los conquistadores españoles en América, Martí destaca al soldado raso Díaz del Castillo que narra la Historia verdadera de la conquista de las Indias y al sacerdote Las Casas defensor de los derechos de los indios y autor de Historia de la destrucción de las Indias. Así se distancia del todo de aquellos que tuvieron que ver con el atropello llevado a cabo 
por los españoles. La figura de Cortés es presentada como contrapartida y antítesis de Las Casas y Bernal Díaz destacándose rasgos maniqueos:

Cortés conoció las rivalidades de los indios, puso en mal a los que se tenían celos, fue separando de sus pueblos acobardados a los jefes, se ganó con regalos o aterró con amenazas a los débiles, encarceló o asesinó a los juiciosos y a los bravos; y los sacerdotes que vinieron de España después de los soldados echaron abajo el templo del dios indio y pusieron encima el templo de su dios. (84)

La selección de figuras destacadas de la historia de la conquista de América es representativa de ambas vertientes en conflicto: los defensores (Bernal Díaz del Castillo y Bartolomé de las Casas) y los opresores (Hernán Cortés). En el relato martiano, sin embargo, se fragmenta lo acontecido y se excluyen datos significativos. Por un lado, Martí reta el intelecto del lector niño al plantearle acontecimientos de la historia del continente americano usando un lenguaje directo y, por otro, después de exponer el tema, excluye y limita acontecimientos y detalles. Su parcialidad incurre en la creación de un entorno narrativo que eleva y destaca sólo ciertos aspectos y figuras, lo que resalta su visión correctora. Tal es el caso de su inclinación a rescatar el capital simbólico de la cultura azteca: “Fueron inocentes, supersticiosos y terribles” (81). Aun cuando los caracteriza, contrapone inocentes a terribles, de manera que siempre encuentra rasgos positivos en su percepción del grupo que favorece. Sus postulados matizan la historia relatada y continúan siendo reveladores de su intención de formar al hombre digno. Al describir la vida en Tenochtitlán antes de la llegada de Cortés y, en particular, a los niños expresa: 
Por una esquina salía un grupo de niños disparando con la cerbatana semillas de fruta, o tocando a compás en sus pitos de barro, de camino para la escuela, donde aprendían oficios de mano, baile y canto, con sus lecciones de lanza y flecha, y sus horas para la siembra y el cultivo: porque todo hombre ha de aprender a trabajar en el campo, a hacer las cosas con sus propias manos, y a defenderse. (84)

Vuelve a reflejarse nuevamente un conjunto de ideas del escritor en cuanto a lo que debe aprender a hacer el hombre y cómo debe considerarse un defensor de la justicia, como hiciera el fraile español. Tras cada exposición o reflexión el autor inserta con sutileza una pincelada de ideología, tiñendo su relato, tutelando al lector. El lenguaje mediante el cual se imparte la enseñanza constituye un terreno de dominación y también un campo de posibilidades para catequizar la formación moral y cultural del lector niño y corregir la impartida por la herencia colonial.

En “El padre Las Casas”, Martí continúa resaltando las cualidades de este opositor de la injusticia cometida por los conquistadores al llegar al Nuevo Mundo. Siguiendo la misma estructura narrativa que usara en "Tres héroes”, Martí describe someramente la formación de este fraile. Luego, da detalles descriptivos de todo lo que les hicieron los españoles a los indios y posteriormente expone su defensa y crítica: “Aprendió en España a licenciado, que era algo en aquellos tiempos, y vino con Colón a la isla Española en un barco de aquellos de velas infladas y como cáscara de nuez” (142). La postura que asume el autor queda claramente expuesta: enaltece la figura de Las Casas y comparte con el sacerdote esa inclinación de resaltar la nobleza e inocencia de las culturas prehispánicas. Destacando las cualidades de los protegidos del sacerdote español, Martí 
enfatiza con abundancia de detalles las atrocidades cometidas por los conquistadores: “iporque en diez años ya no quedaba indio vivo de los tres millones, o más, que hubo en la Española! (144). Sobre de Las Casas dice que a diferencia de sus coterráneos: no los iba cazando con perros hambrientos, para matarlos a trabajo en las minas: él no les quemaba las manos y los pies cuando se sentaban porque no podían andar, o se les caía el pico porque ya no tenían fuerzas: él no los azotaba, hasta verlos desmayar, porque no sabía decirle a su amo dónde había más oro: él no gozaba con sus amigos, a la hora de comer, porque el indio de la mesa no pudo con la carga que traía de la mina, y le mandó cortar en castigo las orejas: él no se ponía el jubón de lujo, y aquella capa que llamaban ferreruelo, para ir muy galán a la plaza de las doce, a ver la quema que mandaba hacer la justicia del gobernador, la quema de los cinco indios. (144)

No puede argumentarse que exista una ruptura entre la narración martiana y los hechos históricos, pero su tono aleccionador y su inclinación a resaltar los infortunios de los oprimidos evidencian las ideas fundamentales que caracterizan su pensamiento y guían al lector implícito, ya sea niño o adulto a favorecer a los colonizados.

Parece existir en Martí una explicación parcial de lo acontecido, una selección de nombres que generaliza o excluye. En este texto al referirse a los soldados llegados de la península, el escritor expresa: “Eran aquellos conquistadores soldados bárbaros, que no sabían los mandamientos de la ley, iy tomaban a los indios esclavos, para enseñarles la doctrina cristiana, a latigazos y a mordidas!” (146). Martí no vacila en exponer que no todo lo hecho por Las Casas merece aprobación. Su visión sobre el sacerdote se 
encuentra enriquecida por elogios y admiración, pero no al punto de excluir un hecho tan repulsivo como la propia explotación de los africanos: “Las Casas, por el amor de los indios, aconsejó al principio de la conquista que se siguiese trayendo esclavos negros, que resistían mejor el calor; pero luego que los vio padecer, se golpeaba el pecho, y decía: “con mi sangre quisiera pagar el pecado de aquel consejo que di por amor a los indios” (150). Con sutileza pero no sin encubrimiento, el escritor hace despliegue de sus más raigales postulados ideológicos, salpicando los elementos constitutivos, sus técnicas narrativas y estilísticas con las ideas que caracterizan su pensamiento y que lo han situado en un puesto privilegiado dentro de la historia y la literatura del continente americano. Si bien Martí establece que uno de los objetivos de la revista es presentar postulados ideoestéticos dando la sensación de que no están ahí, los textos seleccionados en este estudio son ejemplo de esta meta que nunca logra cumplir completamente. 


\section{CAPÍTULO II}

\section{ENTRE COLONIA Y REVOLUCIÓN: UN ACERCAMIENTO A LOS TEXTOS INFANTILES DE LA REPÚBLICA (1902-1958)}

"Lo pasado es la raíz de lo presente. Ha de saberse lo que fue porque lo que fue está en lo que es” José Martí

La culminación del siglo XIX marca el comienzo de un período significativo para la historia de Cuba. La guerra de independencia alentada por José Martí concluye en 1898 y mediante el Tratado de París (1899), España cede el control absoluto de la isla a Estados Unidos. Al no ser asimilada como una colonia, la República de Cuba queda constituida en 1902, con una soberanía mutilada por la Enmienda Platt ${ }^{14}$. La intervención de los Estados Unidos en la guerra de independencia puso fin a la dominación española, pero también interfirió con la plena realización del ideal independentista de los cubanos y generó frustraciones. A partir de 1898, los acontecimientos históricos influyen en diversos aspectos socio-culturales, en la naciente conciencia nacional, y en las producciones literarias. Sin embargo, la crítica ha hecho poco énfasis en la literatura de este período, especialmente en la dedicada a niños y jóvenes. Por lo tanto, este estudio retoma importantes obras infantiles del período republicano con la intención de restituirles el valor que se les ha restado en el imaginario colectivo y aspira a consolidar su valor literario, pedagógico y formativo, con el fin de invertir el desfavorable paradigma.

\footnotetext{
${ }^{14}$ Apéndice constitucional que cedía a los estadounidenses el derecho de intervenir la isla y establecer en ella bases navales.
} 
Un acercamiento a las manifestaciones de la cultura a lo largo de la República permite apreciar la integración de un pensamiento cubano desde búsquedas y posiciones filosóficas diferentes. Explorar las temáticas de la literatura infantil republicana supone un punto de contraste significativo para comprender mejor los giros que se producen en el siguiente período. Durante la República se separa la iglesia del estado y se siguen los modelos estadounidenses de organización para el gobierno y las fuerzas armadas. La degradación y penetración de la sociedad cubana para contrarrestar una cultura nacional y el uso del sistema educativo como instrumento de imperialismo cultural y hegemonía política motivaron el plan anexionista de Estados Unidos tras su intervención. Según el crítico literario y escritor cubano Louis A. Pérez ${ }^{15}$, el sistema educativo de la isla significó la preocupación principal del diseño anexionista (40). El salón de clase se convirtió en el vehículo perfecto para “infiltrar” valores culturales y actitudes políticas norteamericanas, así como para promover la emulación de éstos. De acuerdo con el investigador cubano Rogelio A. de la Torre "uno de los primeros problemas que tuvo que enfrentar el gobierno interventor fue la carencia de maestros debidamente capacitados” (194). La educación del pueblo cubano no había representado una preocupación fundamental para la metrópoli española, por lo que el gobierno norteamericano tomó medidas determinantes para mejorar esta situación. En el verano de 1900, mil trescientos profesores cubanos llegaron a la universidad de Harvard para ser entrenados por dos meses y en 1901, otros doscientos llegaron a Cambridge, Massachusetts (Pérez 47). La introducción del inglés y los textos de historia en el salón de clase moldearon la primera

\footnotetext{
${ }^{15}$ Estos datos aparecen en Essays on on Cuban History: Historiography and Research, publicado en Gainsville en 1995.
} 
generación de estudiantes formados bajo la dominación norteamericana, que a su vez recibieron instrucción de maestros formados en los Estados Unidos. Así se desarrolló un presente colectivo con elementos característicos nacionales y se desmanteló un marco histórico de referencia para los cubanos. Durante la intromisión americana en la isla se contribuyó a distanciar más aún a la sociedad cubana de aquéllas con las que pudiera establecer un vínculo. En este sentido, Pérez observa que: “Cubans were discouraged from seeking identification with cultures other than that of the United States, specifically those societies with which Cuba had the greatest afinity: those in Latin America” (52).

La República se sitúa como un tiempo intermedio entre un período cuyo objetivo principal es alcanzar la independencia con respecto al colonialismo español y una Revolución que provoca la caída de una dictadura para instaurar otra. El antropólogo cubano Fernando Ortiz definió la República como una “cacocracia” debido a la sucesión de gobiernos corruptos y la entrega a los intereses extranjeros. Su posición en la cronología histórica ha logrado asignarle un concepto como el de una época con una literatura indigna de estudios críticos por su carencia de valor ético y literario. Los atributos éticos, ideológicos y contextuales de las obras infantiles representativas de esta época están sujetos a menciones insignificantes o a la omisión por pertenecer a un período que con acierto el crítico literario cubano Rafael Rojas ha llamado 'una edad mediaa ${ }^{16}$ (83). Es una época que como su homóloga media entre dos períodos históricos importantes; en este caso la culminación de la Colonia española y el triunfo de la Revolución en 1959.

${ }^{16}$ Rafael, Rojas, Isla sin fin. Miami: Ediciones Universal, 1998, pp83. 
Para una aproximación contemporánea a los textos infantiles republicanos es preciso revisar la narración de la nación cubana ${ }^{17}$. Este capítulo analiza cómo el contexto social influye en la selección temática, el discurso y la función ideológica de la literatura infantil de la época, con énfasis en El pájaro de lata (1944) de Anita Arroyo, Cuentos de Apolo (1947) de Hilda Perera, Cuentos de todas las noches (1950) de Emilio Bacardí y en dos obras teatrales de Dora Alonso; Pelusín y los pájaros y Pelusín frutero, publicadas en 1956 y 1957 respectivamente. Un paralelismo entre el proceso narrativo de la Cuba que se forjaba como nación y la situación del receptor infantil que nace con cada nueva generación, se establece, en una mutua construcción de identidades.

Las obras seleccionadas de Alonso, Arroyo, Perera y Bacardí integran, junto a Romancero de la maestrilla (1936) de Renee Potts, Isla con sol (1945) de Emma Pérez Téllez, Oros Viejos (1949) de Herminio Almendros y Caballito verde (1956) de Anita Arroyo, un destacado conjunto de producciones literarias en la primera mitad del siglo XX. Sin embargo, una notable semejanza de juicios críticos acompaña los limitados estudios referentes a estas producciones. En opinión del ensayista cubano Jorge Fornet, “la literatura cubana llegó huérfana al XX. Las prematuras muertes de Martí, Julián del Casal y de algunos de sus más notables sucesores, así como la dramática situación política del país, frustraron el ímpetu de que se había gozado pocos años antes” (7). Enfatizando la desolación literaria de la República en cuanto a las producciones infantiles Alga Marina Elizagaray apunta que después de ese feliz comienzo que brinda La Edad de Oro: “descendimos a un gran vacío que duró seis décadas. Nos referimos a la mediatizada República, largos años de predominio imperialista norteamericano en la vida

\footnotetext{
${ }^{17}$ Homi, Bhabha, ed., Nation and Narration. London: Roudledge, 1990.
} 
económica, política, social y cultural de Cuba. No podemos hablar de una literatura para niños y jóvenes en desarrollo hasta después del triunfo de la Revolución” (130). Mirta Yañez plantea que el siglo XX

Se abrió con la flamante -y falseada- república. No eran tiempos propicios para las artes, y hubo algunas que sufrieron con mayor rigor la avalancha neocolonial de Estados Unidos y los percances de una economía subdesarrollada. La literatura infantil, por su doble fragilidad -literatura y dedicada a los niños-, no tuvo buena suerte y los intentos aislados, aunque no alcanzan a desbrozar los enyerbados caminos de la mojigatería, sirven de tarjas indicadoras a la tradición (45). En la misma línea de pensamiento, el poeta cubano Eliseo Diego expresa que “durante cincuenta años de república con minúscula las publicaciones para niños no pasaron del pobre negocio de los libros de textos. La poesía no hallaba mercado -¡qué suerte, a fin de cuentas!- y el manojo de libros salvables se explica sólo por el más cándido de los heroísmos” (83). Mientras que el criterio de Fornet se refiere a la entrada de la literatura cubana al siglo XX de una manera más general, las observaciones de Elizagaray, Yañez y Diego aluden específicamente a la literatura infantil. Sin embargo, la concomitancia entre estos juicios apunta hacia un esfuerzo por resaltar los méritos de las producciones literarias a partir de 1959, mientras se le resta importancia a la etapa anterior. Al rotular toda la literatura infantil republicana con criterios peyorativos, independientemente de su mérito literario se erradica la posibilidad de contrastar el período desde el cual se emiten los criterios con el que le antecede.

Por fortuna, otros estudiosos atribuyen valor a esta época y discrepando de los anteriormente citados validan el panorama literario de la República. Con marcado 
optimismo, Luis de la Paz apunta que “con la República de 1902 el quehacer literario se hace más sólido. Se crean revistas, se publican libros con más frecuencia y calidad” (319). Uva de Aragón asevera que "no se limitaron los hombres y las mujeres de letras de la República a denunciar sus males, forjar un conciencia crítica, alentar, reformar y participar de forma activa en la política. Fueron también grandes promotores de la cultura” (13). El ambiente no parecía propicio para la creación. Sin embargo, y en plena conciencia de la frustración; educadores, intelectuales y artistas contribuyeron a la solidificación de la identidad nacional.

Varias publicaciones infantiles evidencian que en el quehacer intelectual y social de la época hubo una preocupación por los lectores más jóvenes. En 1920 se publica mensualmente el periódico "Pulgarcito".

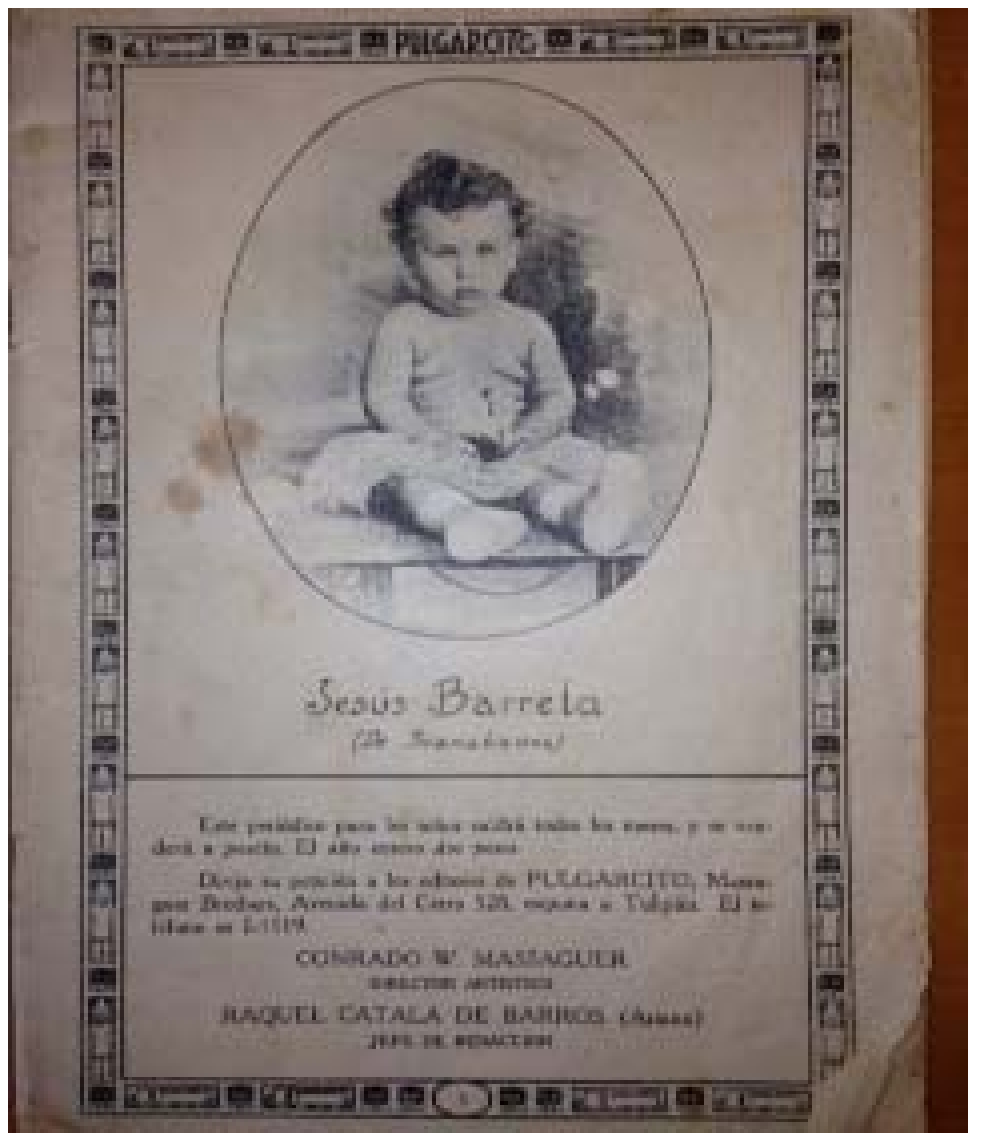


Portada del periódico "Pulgarcito". Vol 2 \# 5, abril 1920. Cortesía de Cuban Heritage Collection, Universidad de Miami.

Este periódico, cuyo costo mensual era de una peseta y la subscripción anual era de dos pesos, incluía una sección de modas, una de pasatiempos y una nota cómica. En la “Galería de los propietarios infantiles” el periódico publicaba la foto de un niño propietario de un solar. La siguiente imagen, también perteneciente al Vol 2 \# 5 de abril 1920 es representativa de esta sección en particular.

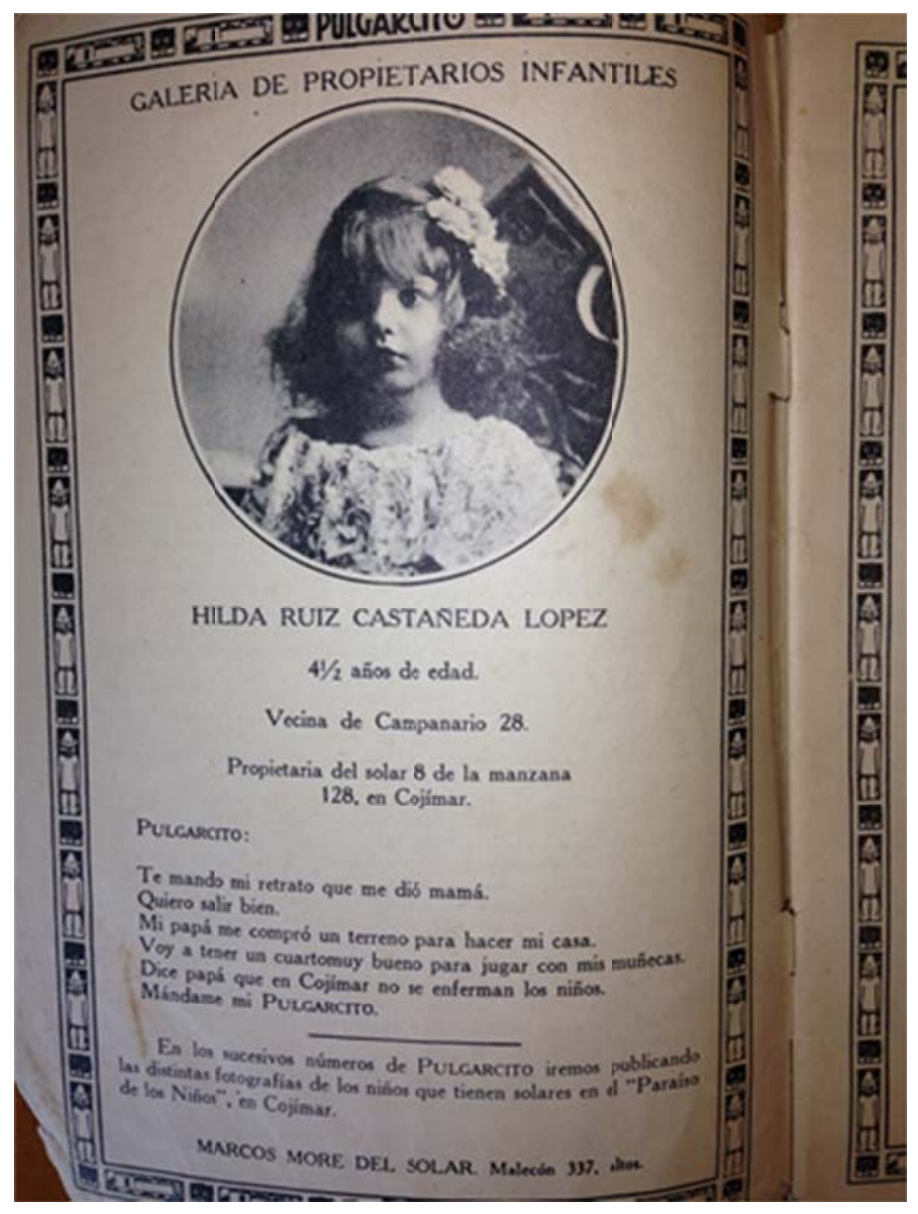

Fotografía cortesía de Cuban Heritage Collection, Universidad de Miami Una publicación quincenal es la revista "Martí", cuyo primer número se publicó en La Habana el 15 de abril de 1929. Entre sus secciones incluía: "Pasatiempos y curiosidades”, 
"Juegos infantiles”, “Figuras de la historia”, "Lecturas del hogar”, "Página humorística” y "Galería de honor" en la cual se publicaban fotos de estudiantes destacados refiriendo el colegio al que pertenecían y el honor o distinción recibida. Incluía, además, la "Página de risa” y el "Recreo de los niños” en el que se publicaban textos enviados por los lectores.

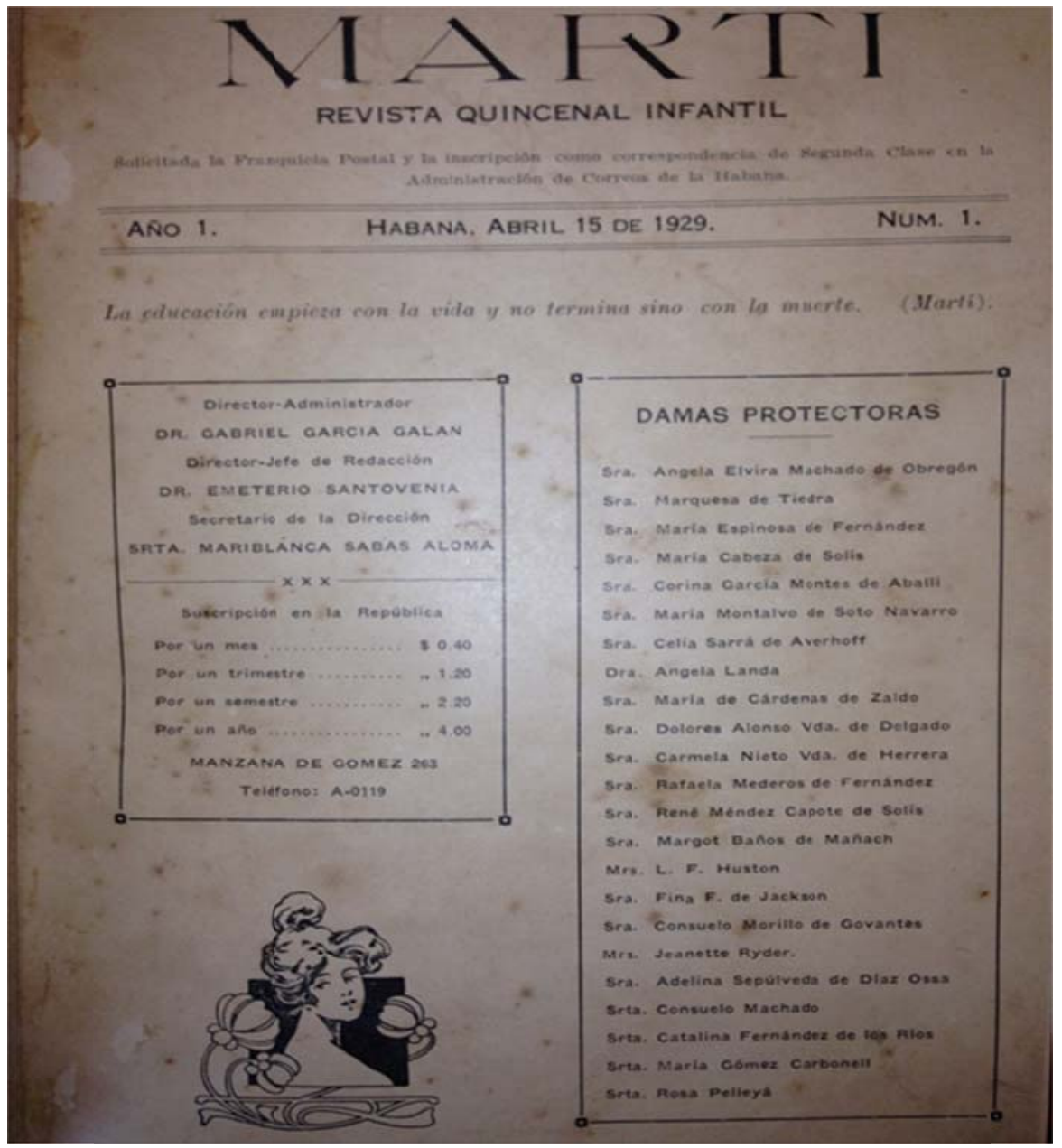

Fotografía del ejemplar del 15 de abril de 1929. Cortesía de Cuban Heritage Collection, Universidad de Miami.

Entre las publicaciones de escritores extranjeros figuraban los nombres de Gabriela Mistral, Edmondo de Amicis y Amado Nervo mientras que el nombre de José 
Martí era el más recurrente entre los escritores nacionales. En la publicación de septiembre de 1929 aparece una sección titulada "Postalitas: de charla con los niños” que se encontraba a cargo de 'la Abuela’ y a partir de ese momento se continúan incluyendo en la revista. La abuela especifica que sus cartas serán muy cortas (sus charlas) y les ruega a los niños que sus cartas vengan en forma de postalitas. Las postalitas eran para el hogar y el niño. A las madres estaba dedicada la sección “El cuidado del niño”, redactada por el Dr. Alfonso G. Alarcón. Otras dos revistas de publicación mensual son "Ronda” (1941-1943), fundada por el pedagogo y escritor español Herminio Almendros y “Pinocho" (1941-1942).

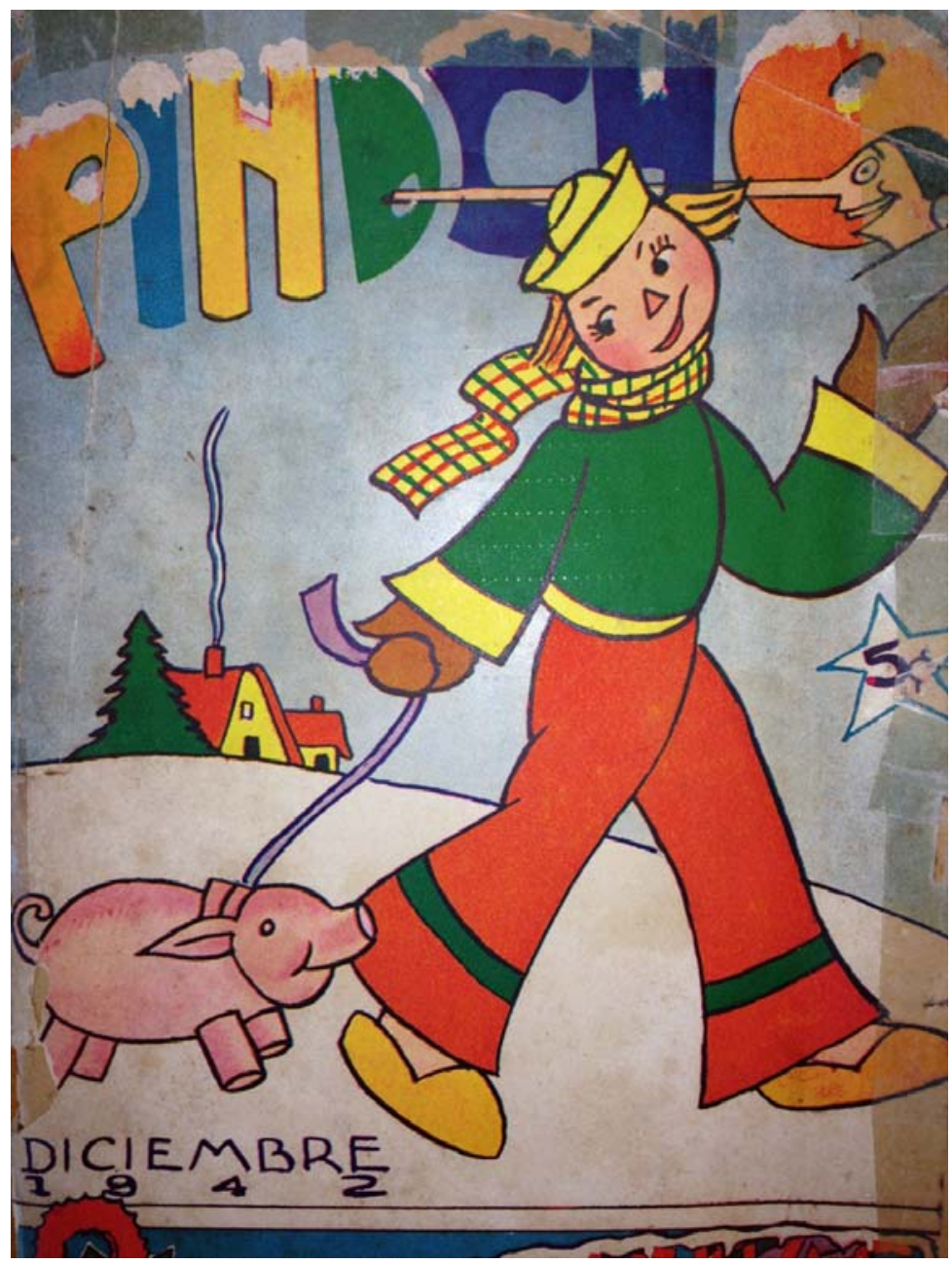


Fotografía de la portada de "Pinocho" de diciembre de 1942. Cortesía de Cuban Heritage Collection, Universidad de Miami.

Mientras que en "Pinocho" los trabajos para armar con instrucciones y figuras eran elementos fundamentales, en "Ronda” se publicaban poemas, canciones populares infantiles, crucigramas, secciones de pasatiempos, convocatorias para concursos y adivinanzas, además de una sección titulada "Documental geográfico”.

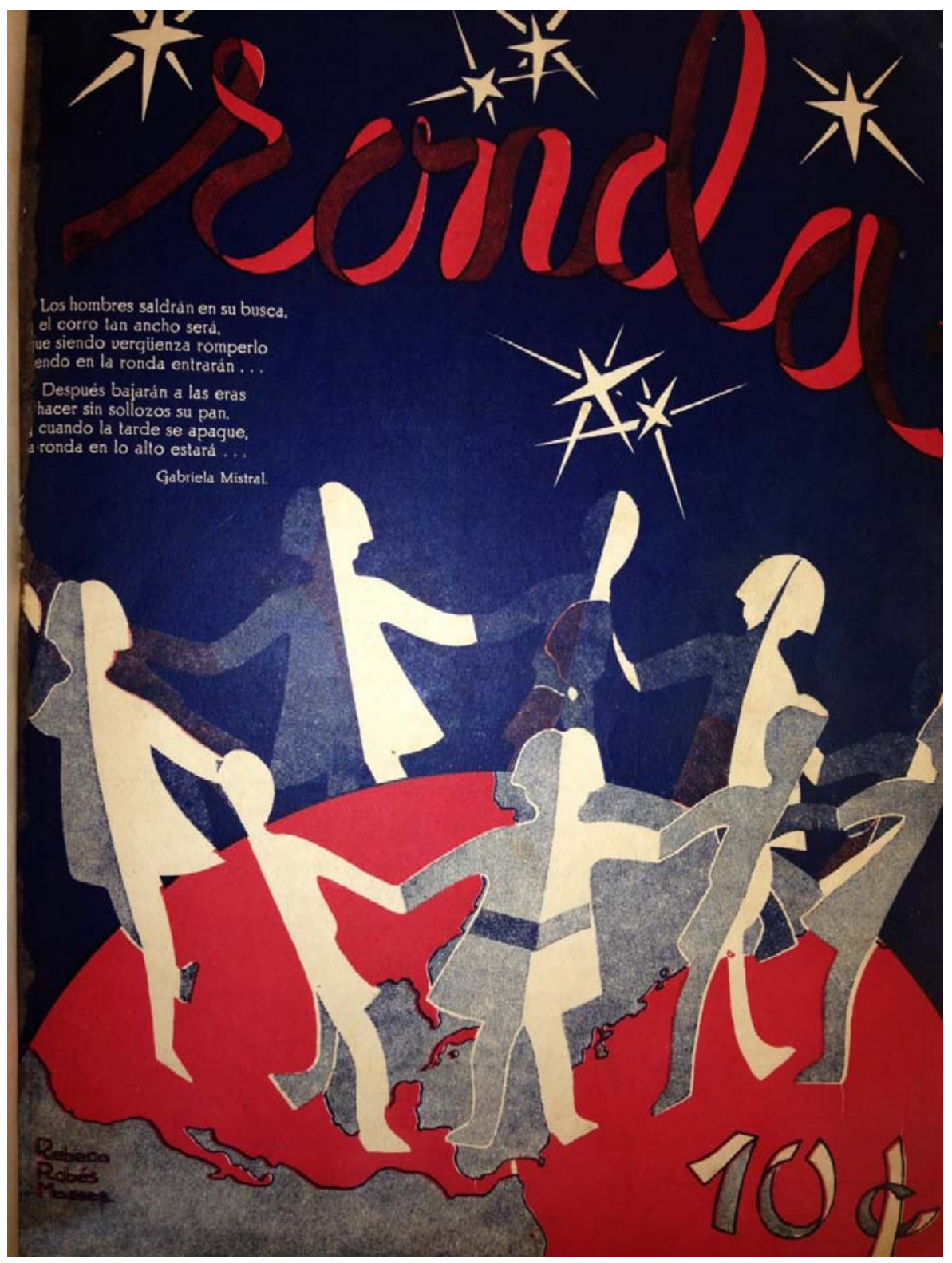


Fotografía de la portada de no. 1 de octubre 1941. Cortesía de Cuban Heritage Collection, University of Miami.

Estas revistas infantiles no sólo evidencian el acierto de la observación que Luis de la Paz realiza en cuanto a la creación de revistas durante la República sino que específicamente arrojan luz sobre las dedicadas a los niños y son antecedente importante de las obras narrativas que este estudio analiza.

En su conferencia “Qué es la nación” (1882) Ernesto Renán sostiene que “la esencia de una nación es que todos los individuos tengan muchas cosas en común, y también que todos hayan olvidado muchas cosas” (66). En la construcción de la nación cubana, asalta una interrogante: ¿comparten todos sus individuos las mismas ansias de independizarse de un modelo extranjero impuesto y, de ser así, cómo manifiestan esas ansias? Las primeras generaciones republicanas comparten la influencia del modelo norteamericano en todos los aspectos pero también un interés por lo más representativo de la nación cubana. Todo el quehacer literario del siglo XIX se va integrando en busca de la identidad propia y en la formación de una conciencia histórica, fundamentos que sustentan las guerras por la independencia (1868-1878) y (1895-1898). La denuncia de males sociales y políticos influye significativamente en las creaciones de los primeros escritores, los cuales representan una imagen de la nación con sentido cubano, fusionando elementos hispanoamericanos como las figuras históricas, la geografía, el humor caribeño y lo universal. Cuba, a diferencia de otras naciones latinoamericanas carece de una población indígena con una antigua cultura y un pasado prehispánico, lo que Jorge Mañach refiere como “la carencia de una imagen histórica apropiada” (47). El pasado común esencial para la consolidación de una nación en el caso de la isla se remonta a su 
etapa colonial y en la República se adopta una actitud de rescate de los valores propios a partir del pasado histórico-cultural. De acuerdo con Mañach, la imagen histórica predominante en Cuba durante las décadas centrales del siglo diecinueve se resolvió en tres fórmulas distintas de acción política: el separatismo romántico, el anexionismo y el reformismo” (52). Rafael Rojas, por su parte, concluye que la literatura cubana aborda la identidad nacional desde dos discursos paralelos: por un lado participa como nación en la identidad cultural de Latinoamérica y por otro la identidad nacional de Cuba sobresale del marco general de Latinoamérica y sin embargo pertenece a él. (241 Gallery of Cuban writing).

\section{Construcción de una identidad nacional: El proceso cubano}

Al referirse al punto cero de la sensibilidad social en el caso de Cuba, Jorge Mañach traza la representación de lo autóctono a partir del nombre que recibió la isla en distintos momentos históricos. El escritor observa que al sustituir el nombre aborigen, Cuba, por otras designaciones como Juana y Fernandina, la Corona reflejó la imagen oficial de la conquista, su sentido patrimonial y absolutista: “ignorando el nombre natural de la isla, se niega toda voluntad nativa... el indio, de entrada, no cuenta” (Mañach 59). Sin embargo, Juana y Fernandina tampoco serían designaciones permanentes, sino que quedarían desplazadas por el nombre natural “Cuba”, lo que el escritor considera "la primera reivindicación oscura de lo autóctono. El embrión de la sensibilidad criolla frente

a la autoridad oficial” (59). De acuerdo con Mañach, las otras designaciones que suceden son La Habana y, más tarde, cuando a finales del siglo XVIII comienza a existir el resto de la isla, el País. Esta última designación representa “una denominación interna, como interna es la conciencia del momento. Representa la segunda reivindicación, ya más 
deliberada, de lo autóctono" (Mañach 60). A la etapa de "el País", sigue la de "la Isla”, cuando Cuba ha descubierto su propia insularidad. Mañach apunta que después de la doctrina de “pueblo cubano” que Martí erige “quedó entonces Cuba lista para efectivamente para lograr la nación, que es cosa muy distinta a la mera nacionalidad jurídica” (63). Martí es una figura clave de la narrativa modélica que amalgama historia y ejemplaridad para la consolidación nacional, mientras ensalza la edificación moral.

Con relación al surgimiento de la República, Mañach apunta que "la formación de la conciencia cubana, que se inició a principios del siglo XIX bajo tan prometedores auspicios, se quedó detenida” (47). Sin embargo, diferentes generaciones de intelectuales cubanos han interpretado la identidad nacional basándose en la intersección de raza, clase, ideología y otras variantes. Dora Alonso, Anita Arroyo, Hilda Perera y Emilio Bacardí forman parte de ese grupo de intelectuales que contribuye a crear durante la República los antecedentes de una nueva época de la nación cubana en la que se reafirma el valor de la cultura nacional y lo autóctono. En sus obras para niños y jóvenes estos escritores unen a la designación natural de "Cuba” los elementos que caracterizan al campo, la ciudad y el pensar y sentir del pueblo cubano.

Publicado inicialmente en 1944, El pájaro de lata está dedicado a todos los lectores de habla hispana, pero en especial a los niños cubanos. La autora ha tenido la oportunidad de recorrer la isla y quiere que sus lectores conozcan su patria, especialmente su flora y fauna. Mediante el acercamiento a la geografía y la historia de Cuba, Arroyo se propone captar la atención de su destinario y familiarizarlo con los paisajes y tradiciones de la isla. Se alude también al aspecto sociológico dada la descripción de tipos y costumbres populares en el ambiente rural. La colección de cuarenta cuentos muestra un 
estilo en el que predominan la sencillez, la sobriedad y la brevedad. No son princesas, corsarios ni piratas los personajes que se presentan, sino niños de ocho a diez años de edad que son aprendices de alfarero, vendedores de billetes de lotería o de conchas, guajiritos o pícaros.

Una selección de ejemplos analíticos en los cuentos que integran El pájaro de lata permite apreciar las temáticas recurrentes así como las funciones ideológica, nacional y cívica en éstos. Si Martí expresa que ‘los niños son la esperanza del mundo” ubicándolos en el futuro, para Anita Arroyo son ya ‘todopoderosos’ porque se fabrican sus sueños y viven a través de su imaginación. El cuento “El pequeño descubridor” conecta la exploración del mundo y de la patria a través de los ojos infantiles con el fascinante descubrimiento de América. Se introduce la figura de Cristóbal Colón mediante una terminología sencilla, que educa mientras entretiene. El incentivo a recorrer la isla es explícito, así como la responsabilidad que el destinatario tiene de explorarla, de escoger sus calificativos para describirla, como lo hace la autora y como lo hizo Colón.

“El pájaro de lata” es, además del título de la obra, el cuento que nos revela qué o cómo pudiera ser el ave fabricada de ese metal. Es también el primer cuento de la colección en que se alude a una región geográfica, Baracoa, y se menciona uno de los personajes más significativos, el guajiro. Una descripción de la orografía de esta región oriental sirve de marco introductorio para que Yayo, un guajirito de siete años aplaque su miedo de ese aparato ruidoso que vuela y que su madre le dice que es un pájaro de lata. La autora incluye vocablos característicos de la vida campestre y el ambiente rural como el platanal, la loma y la batea de madera. Se contrasta también la vida de la ciudad con la del campo. Si los niños de la ciudad de Baracoa no han visto nunca un tren, los del campo 
han visto menos, ni siquiera saben cómo es un automóvil. Esta comparación no es desatinada. La oposición ciudad-campo le ofrece a la voz narrativa la posibilidad de establecer una distinción de clases: “no te extrañe que jugara en la tierra”-dice la autora acerca de Yayo- "La gente pobre no tiene otra cosa que dar a sus hijos” (26).

El ambiente autóctono cubano continúa enriqueciéndose en el cuento “Oro verde”. Baracoa es nuevamente la región protagonista, en este caso porque su mayor riqueza es el oro verde: los plátanos Johnson o 'guineos’. Reaparece la figura del guajiro, gondolero caribeño que canta sus décimas guajiras mientras desciende por el río transportando el cargamento de plátanos hacia la ciudad, para luego ser exportados a los Estados Unidos. Un suelo productivo ejemplifica la riqueza natural de la isla, que a su vez brinda el caudal más valioso de elementos nativos.

En "El colector de conchas" no es el guajiro el protagonista de este relato, sino el pescador y, junto a él, la playa, la atarraya, la cosecha del mar, el bohío. El habla coloquial de pescadores se aprecia en frases como ésta: “Aquí que va a haber 'ná'...Aquí sólo hay ‘necesidá’ y mucha hambre” (32). Varadero es el destino geográfico que la escritora elige para narrar la historia de Manolín, el más pequeño de una familia de pescadores que disfruta mucho su oficio de 'colector de conchas'. El protagonista conoce las conchas y también la miseria: “una sardina quemada, era lo que parecía aquel niño miserable” (29). Nuevamente se establece una desigualdad de clases: los pescadores y la gente rica de la playa. Allá, al otro lado de la barranca, se encuentran las nuevas construcciones, las lujosas residencias, mientras que en el bohío de Manolín y su familia caen goteras. Resalta, sin embargo la honradez del hombre humilde y el niño posee una 
integridad modélica, inquebrantable, que se erige como pilar ante los bienes materiales que posee la clase acomodada.

Si bien Baracoa es el escenario de varios de los cuentos en la obra, Varadero también recibe protagonismo y nos atañe en el relato “La rosa de conchas”. La presencia norteamericana en el relato se muestra en los personajes de ésta nacionalidad y en la alusión a la culminación de la guerra de Independencia. Los visitantes se familiarizan con la tradición de Los Reyes Magos durante su estadía en Varadero y deciden desempeñarse como las majestades del hecho bíblico para obsequiar a Raúl, el protagonista de doce años, uno de los vendedores de objetos de conchas de Varadero. Con estilo narrativo llano y vigoroso la autora ofrece un relato de intrínseco contexto histórico republicano, pero con una conciencia de clase que facilita la múltiple perspectiva analítica. La figura foránea significa el cambio positivo, en términos materiales, para el personaje representante de lo autóctono: la infancia campesina cubana. La miseria que caracteriza a Raúl es evidenciada por términos como: "andrajos”, "las marañas de sus pelos rubios”, “camisitas rotas”, “los ripiados arapos” y “el mísero bohío”. Visto desde una perspectiva material la intromisión del vecino del norte representa una posibilidad de mejoría, pues Raúl queda como nuevo después que sus improvisados y bondadosos Reyes Magos lo visten y calzan. El personaje principal, sin embargo, representa también la bondad de espíritu ya que no sólo dedica el dinero de sus ventas a comprar regalos para sus hermanos sino que le obsequia al traductor que le había facilitado la comunicación con los turistas una bella rosa de conchas que presenta diciendo: "for you”. La contraposición de lo foráneo y lo autóctono siempre da la sensación de que en lo cubano existe una mayor riqueza, esa que no puede comprarse 
porque está compuesta por cualidades que engrandecen al ser humano. Una exploración de las condiciones de la infancia cubana en el campo, usando a Varadero como región geográfica le permite a la autora resaltar rasgos autóctonos de un segmento de la población cubana y familiarizar al lector con el ambiente y los tipos característicos de dicho ambiente.

Las particularidades de los habitantes de cada espacio o región que la escritora elige están estrechamente relacionadas con el entorno. De tal manera en "El alfarero" existe un paralelismo entre la profesión y el tinajón típico de la región de Camaguey. En este cuento, sin embargo, más allá de la conexión que puede establecerse entre región y objeto representativo, se aprecia un postulado martiano. Lalo, un niño de cinco años es el aprendiz de alfarero y para la autora, en una frase que recuerda el concepto de infancia de Martí “él también es arcilla fresca que moldear” (53). Seleccionar a niños entre las edades de siete y diez años como los protagonistas principales en la mayoría de los cuentos de $E l$ pájaro de lata es indicativo de la importancia que otorga la escritora a la generación futura, de la responsabilidad que tiene el escritor de obras infantiles de transmitir valores cívicos, enseñanzas morales y principios. Los postulados martianos en cuanto a la educación y la función formativa de la literatura infantil se hallan presentes en la ideología de una escritora de la etapa republicana como Anita Arroyo. Sus relatos evidencian el esfuerzo por familiarizar al receptor con su patria mientras se construye la identidad nacional mediante el uso de elementos simbólicos y representativos, del uso del niño como metáfora de un país que no conoce la modernidad, y que, como la generación nueva, comienza a forjarse. 
La influencia martiana se vislumbra en la estructura y trama del cuento "María Panetela”. El lector familiarizado con La Edad de Oro, no puede pasar por alto las semejanzas existentes entre “María Panetela” y “La muñeca negra”. Las protagonistas de ambos relatos son niñas de ocho años de edad, pertenecientes a familias acomodadas, cuya mejor compañía es una muñeca con características peculiares que retratan a las clases marginadas. Rosita, la protagonista de "María Panetela” debe desprenderse de su muñeca de trapo cuando su madre le pide que la regale a la hija del carnicero que ha quedado huérfana. Para Rosita, María Panetela es su muñeca favorita y le brinda más cariño a María Panetela por ser su muñeca más fea y débil, la ‘de mirada lastimera’ y sufre con dolor de madre al desprenderse de ella. Rosita, sinónimo de belleza, lozanía y perfección contrasta con "los labios rojos, siempre abiertos y la nariz chata, de ventanas abultadas como aletas de pescado” (45) de María Panetela.

En “María Panetela” la diferencia de clase se ve reflejada en la elección léxica que usa la madre de Rosita. Al pedirle que le regale su muñeca de trapo a la hija del carnicero expresa que: “son dignas de lástima esas gentes” (46), dando la sensación de superioridad o distanciamiento. El hecho de que Rosita tenga más muñecas y pueda regalar una indica que pertenece a una clase más acomodada. Una lectura paralela de ambos cuentos permite apreciar sus similitudes temáticas e ideológicas. La escritora se propone despertar un sentimiento de compasión en el lector, no sin antes destacar, desde una perspectiva superior, las posiciones que diferencian a quien da de quien recibe cariño.

El influjo martiano se aprecia también en el cuento “Las tinajitas”. El espacio seleccionado por la autora en este relato es la ciudad de Trinidad, reconocida por su 
legado arquitectónico colonial. En esta narración se aportan datos históricos relevantes que capturan el interés del lector y aleccionan en cuanto a historia y arte, con sutileza y agrado. Provee además, una fuente de información histórica para los lectores y un modelo de costumbres de antaño. La mención de Hernán Cortés, Humbolt y el padre Las Casas le propician al lector-niño un primer encuentro con destacadas figuras históricas. La autora crea una relación entre el presente y el pasado colonial a través de una descripción de la arquitectura, las calles y las tradiciones. Los trinitarios se complacían en construir palacios, explica la escritora. Dado el cariz inmemorial de la ciudad, utilizarla como escenario del relato permite la inmersión en el pasado. Tras una descripción que sigue el modelo martiano comienza el desarrollo de la historia, que acontece, precisamente en uno de esos palacios. Las tinajitas es el apodo que ha dado el pueblo de Trinidad a tres hermanas que habitan, como reliquias, en una de esas esplendorosas construcciones que sobrevivió a la historia. Atraída por el valor del pasado y la importancia de su preservación para el enriquecimiento cultural del presente, la escritora explora temas como la ruina de tesoros arquitectónicos y las repercusiones negativas que tiene a nivel artístico. Con el objetivo de concientizar a las generaciones futuras sobre este fatal descuido, Arroyo hace un llamado explícito a las autoridades: "He ahí un tema digno de estudio para el Patronato Pro Urbanismo de Cuba, para el Gobierno, que nunca ha hecho nada por conservar nuestros tesoros artísticos, para los niños, para todos los cubanos que de verdad aman a su patria” (227). En la voz autoral predomina la denuncia gubernamental directa, así como también la preocupación por conservar el legado cultural para las generaciones venideras. 
En los cuentos que integran El pájaro de lata la diversidad temática comparte un locus amoenus: el campo cubano, su ambiente autóctono en las diversas regiones de la isla. Hay un innegable paralelismo entre el eje central del relato y los hechos históricos que marcan el comienzo de la República. La relación entre el personaje y su entorno es representativa de uno de los objetivos de la autora: familiarizar al lector con las "raíces” cubanas fomentando en su imaginario el apego a todas las provincias del país y la identificación de tipos y costumbres con cada ambiente. Por tal motivo el guajiro es el personaje al que se alude con frecuencia y el ambiente rural el escenario propicio. De igual forma se enfatizan otros elementos y personajes que contribuyen al desarrollo de las funciones ideológica, cívica y nacional. El texto contribuye a la formación de una conciencia nacional mediante su acercamiento geográfico e histórico. Arroyo se acerca a la infancia cubana a través de un recorrido en el que descuella la caracterización física de personajes y lugares. Publicado durante la primera mitad del siglo XX y bajo una fuerte influencia norteamericana, El pájaro de lata se arraiga a la fundación de las raíces y la autonomía nacional, cultural y social. De ahí que las tramas de los cuentos ensalcen la riqueza y diversidad de paisajes y localidades, que se enfaticen figuras nacionales como José Martí y Máximo Gómez. Aun cuando en relatos como “La rosa de conchas” se alude a "los turistas norteamericanos disfrutando de nuestro delicioso invierno en la playa más bella del mundo (Varadero)” (175) se coloca mayor peso en los calificativos que describen el entorno nacional. La presencia del vecino del norte aparece como recordatorio del período histórico al que se alude mientras se produce una aprehensión a lo autóctono. La ideología nacional de Arroyo resume que todo niño cubano debe conocer su patria y proyecta el mismo mensaje a todos los niños del mundo al prologar 
ediciones posteriores. Su ideología social, sin embargo, no queda exenta de la división de clases. Como Martí, la escritora intenta promover la igualdad social, pero ella misma crea distinciones en frases como: "los pobre no tienen con qué comprar juguetes” (177), que denotan lo que el narratólogo Wayne Booth llamaría “distanciamiento” entre la voz narrativa y los personajes.

Otra escritora para quien conservar la identidad cultural es objetivo fundamental en sus textos para niños y jóvenes es Hilda Perera. En 1947 con sólo 17 años de edad, Perera sorprende al público y a la crítica cubana con la publicación de Cuentos de Apolo. En una entrevista que le realiza el escritor cubano Sergio Andricaín a Perera en 2003, al aludir a su primera obra la escritora nos familiariza con la trama y con sus motivos para escribirla: “Desde niña me conmovía mucho ver a los niños negros que vendían periódicos, a veces sin zapatos. Producto de esa conmoción nació el personaje de Apolo, un niño negro y pobre. Una vez que me salió el personaje, se dedicó a vivir por su cuenta y yo solo tuve que salir atrás corriendo para escribir lo que él hacía”. Desde su publicación en 1947 Cuentos de Apolo ha disfrutado de reediciones y continúa cautivando a lectores. Sin embargo, a pesar de haber recibido el halago de la crítica, la primera obra de Perera no se destaca en las antologías literarias y estudios críticos más allá de la mención. Esto puede deberse a que pertenece al período republicano y al hecho de que Perera haya publicado la mayor parte de su obra en el exilio, tras abandonar Cuba a principios de 1960. Lo que no deja espacio para suposiciones en la obra de Perera, y en especial en Cuentos de Apolo, es la intención de la escritora de reafirmar la identidad cultural cubana: "Deliberadamente en todos mi textos para niños y jóvenes reafirmo nuestra cubanía, e insisto en que no se pierda nuestra identidad cultural frente a las 
presiones de una cultura ajena, es este caso la norteamericana” (Perera 27). Por ser una escritora que reside en una Cuba bajo la influencia norteamericana cuando se publica la obra y que posteriormente residiría en Estados Unidos, la referencia a la pérdida de identidad cultural frente a la cultura norteamericana tiene una doble implicación desde la perspectiva histórica. Por un lado la escritora valida la identidad cultural en las nuevas generaciones de cubanos nacidos en Norteamérica. Por otro, y haciendo un viaje retrospectivo a la República contribuye a la consolidación de la nación. La reafirmación cultural en Cuentos de Apolo, por lo tanto, trasciende períodos históricos es representativo de cubanía.

La mirada de Apolo, un niño negro de siete años, es el lente a través del cual se contrastan las diferencias sociales, raciales y geográficas más representativas del período republicano. La integridad del espíritu humano y el valor de las aspiraciones y los sueños son parte esencial de la trama en la que vale la pena explorar cómo Perera brinda una peculiar representación de la identidad cultural y nacional.

Para representar las tensiones sociales de su tiempo, la escritora crea una obra infantil narrada en tercera persona y compuesta por viñetas. El ambiente rural es escenario central durante el período de 1900-1959. El hecho de que el personaje principal viva con sus padres y hermanos en el campo favorece el predominio de elementos campestres: las palmas reales, el trillo, la flora y la fauna. Esa circunstancia resulta idónea para representar los rasgos más distintivos del campo cubano, incluyendo el modo de vida, las costumbres y el habla del campesino. Se presenta además, como el escenario perfecto para establecer un contraste con la ciudad. El campo es el lugar en que el árbol ríe, hay palmas reales, ceibas y un olor a limpio que emana de las sábanas recién lavadas 
que tiende la mamá de Apolo, Pancha. La Habana, por el contrario, intimida al niño. La inmensidad del cielo no es infinita, sino rectangular y, teme perderse. La visita de Apolo a la capital culmina con una añoranza de su campo, “tenía polvo y cansancio de la ciudad metidos dentro, y sintiendo que prefería su bohío, y el parche verde de la caña, y el surco amigo de la tierra, se acurrucó en un sueño” (22). Para la escritora es necesario acercar más al personaje principal a lo autóctono de la cultura cubana, de manera que el lector tenga la oportunidad de conocer más a fondo sus raíces. Cuentos de Apolo contribuye al esfuerzo de ensalzar y representar los distintos ambientes del país, así como sus tipos y costumbres. Hay un aprecio del cuerpo físico de la nación, de su paisaje, de sus tipos e indumentos, de cuanto representa un rasgo o un patrimonio colectivos. Aunque predomina el colorido local, el carácter de la obra no es regional. Los valores y las temáticas que se tratan en son universales, y por lo tanto reconocibles para cualquier lector niño o adulto.

El personaje principal tiene una sed de conocimiento y aventuras insaciable. Sus limitaciones son de índole material, pero su ingenio, carisma y bondad superan las necesidades materiales que acechan su entorno. Si para los hacendados criollos la cultura era una empresa de los blancos, Apolo subvierte ese paradigma al mostrar su inquietante curiosidad por aprender. Aunque Cuentos de Apolo "fue criticado en alguna ocasión, a partir del criterio de que era la visión de una escritora blanca de clase media acerca de un niño pobre negro” (Perera 27), La inclusión de un personaje negro es doblemente significativa ya que "los negros, en tanto no se les reconocía su estatus existencial humano, no eran portadores de cultura” (Pupo Pupo 38). Como representante del componente negro sobre el cual se forja la cultura cubana, Apolo es símbolo de un 
intento de integración racial. El hecho de que sea un niño cuya apariencia física no se ajusta al ideal de belleza del discurso colonial "negro, ágil y brilloso, son los dientes lo único verdaderamente blanco en su cara” (11), denota una intención de representar los rasgos de una parte de la población cubana a la que también se la ha de atribuir protagonismo en el decurso histórico. La ascendencia africana de Apolo le permite a la autora explorar el sincretismo que existe en la cultura cubana, representar mediante el lenguaje escrito el culto a las imágenes religiosas y sus equivalentes africanos. Apolo cumple una función doblemente importante en la conformación nacional: por un lado su condición de niño lo posiciona como representante de la generación futura y por otro, sus rasgos físicos validan la integración racial en la construcción de la nación; sus valores reflejan la integridad que debe tener el hombre como individuo y como ciudadano.

La técnica narrativa de Perera se distancia del aleccionamiento explícito y despierta la simpatía del lector por Apolo, no mediante la condena de las actitudes de los personajes de los que se diferencia, sino engrandeciendo los valores que hacen al personaje principal tan entrañable y único. Cada personaje secundario resulta determinante en la representación de un sector religioso, la clase social y el rango. Existe una estrecha relación entre lo que simbolizan estos personajes y la nación que se construye mediante la narrativa. En el caso del cura Francisco, por ejemplo, la función promordial es la de representar la iglesia católica y la religión más practicada en la isla: el catolicismo, legado de la colonia española. La señora Adela, blanca y de clase media es la tutora que corrige los errores lingüísticos de Apolo. Sin embargo, la recurrencia de los mismos es como un recordatorio de que precisamente en ellos reside la riqueza del discurso oral campesino. La profunda afinidad de acentos (explicar) deja a salvo las 
expresiones individuales y en ello se puede encontrar el sello de lo nacional. La expresión de Apolo, sincretiza los elementos campesinos y africanos. Son múltiples los ejemplos de frases de que constatan esta observación, como por ejemplo en la siguiente conversación con Adela:

-Bueno, Apolo, si me prometes seguir viniendo, te daré diez centavos. ¿Prometido?

-¿Pa bení toa la tarde?

-Para venir todas las tardes.

$-\dot{\mathrm{C} Y}$ lo domingo?

-Los domingos vas a misa.

-¿No e lo mimo que le mueba la tierra del jardín na má? (33)

Identificar la voz de Apolo resulta bastante sencillo. Su expresión es característica, representativa del entorno en que se desenvuelve, en el contexto familiar y social.

La voz de Apolo es fundamental para narrar y explorar cómo el campo, la pobreza, los marginados y los valores patrios, son parte fundamental del contexto histórico y mediante su comprensión se puede no sólo representar, sino contribuir a la construcción de la identidad nacional. Su lenguaje es llano, rico en expresiones que transportan al lector a un escenario determinado, a un paraíso campestre tan representativo del paisaje rural de la isla: "Desde la sombra nacen el bohío, las palmas, el azul del cielo y el verde interminable” (25). Con un estilo en el que predominan las metáforas, la escritora invita al lector a realizar un recorrido por una trama en la que se otorga más valor a lo que se demuestra con imágenes que revelan detalles de Apolo desde su indumentaria: "se viste con un pantalón que había sido azul” hasta la irónica distancia 
que lo separa del mar: “Apolo vive a treinta y cinco centavos del mar; pero nunca lo ha visto” (11). Apolo proyecta las cualidades que ha de tener el individuo que forja la nación: amor a lo autóctono, respetar la naturaleza y a las personas, pero sobre sobre todo, tener aspiraciones que superen los cercos sociales y las limitaciones materiales. Apolo se despide del campo cuando sus padres deciden mudarse a otra provincia. Su partida, sin embargo, tiene lugar cuando ha pasado sus mejores años de infancia en él. El recuerdo que conserva del campo se nutre del conocimiento empírico, de las vivencias disfrutadas, que refuerzan su vínculo con la tierra, con la patria. Su desplazamiento es territorial, pero sus memorias tienen un sentido arraigado en el valor nacional.

Cuentos de Apolo es una contribución significativa para la literatura infantil cubana y universal, un acierto literario que conserva su frescura y atractivo a más de cincuenta años de su primera edición. Aunque una notable afinidad de juicios críticos acompaña los limitados estudios referentes a las producciones literarias infantiles de la República, la lectura atenta de los textos más destacados y en particular de Cuentos de Apolo de Hilda Pereda revela que se debe replantear este paradigma ya que la obra no sólo es reflejo de las circunstancias históricas de la nación en un período determinado, sino que la trama que desarrolla la escritora reúne elementos que representan y contribuyen a construir la nación cubana de una manera inclusiva. Con madurez y un estilo depurado Perera proyecta en Cuentos de Apolo una trama enriquecida por el contexto social de la época y por un arraigo vehemente a lo más autóctono de la identidad nacional.

El contexto social de la República también nutre Cuentos de todas las noches (1950) de Emilio Bacardí, publicación póstuma que realiza la hija del autor, Amalia 
Bacardí. De acuerdo con la percepción de la hija, los cuentos son "ricos en fantasía poética, en sentido educativo y tan cubanos como su propio padre”. Como en las obras de Dora Alonso, Anita Arroyo e Hilda Perera que conciernen este estudio, en Cuentos de todas las noches hay una proyección de la conciencia cubana. Sin embargo, en las narraciones de Bacardí se introduce la figura de un narratario, hay una caracterización ideológica y social de los personajes ligados a un contexto social y se exploran las relaciones entre los personajes como metáforas de poder.

Aunque el narratario puede indicar distanciamiento ideológico del narrador con respecto a sus personajes o a la historia que relata, no parece ser ése el caso en la obra de Emilio Bacardí. El claro encabezamiento "Pues señor” en cada cuento, aunque media entre lector y escritor, no impide que la voz del autor se filtre y su opinión sobre diversos aspectos quede explícitamente develada. En el cuento “El plátano guineo”, especie de fábula en la que los personajes son ratones, hay una crítica directa a la soberbia del hombre: "Porque los animales -lo mismo a los que van sobre cuatro patas que a los que van sobre dos- no les gusta que se les diga la verdad” (30). El plátano guineo que en los cuentos de Anita Arroyo es fuente vital de sustento y de alimentación, “oro verde”, en el cuento de Bacardí es alimento que utiliza el dueño de un almacén para envenenar a los ratones que tantas pérdidas le habían causado. El plátano, puesto con fósforo para que el resplandor deslumbrara a los ratones es también vehículo que alecciona sobre la falsedad de las apariencias, pues todo lo que brilla no es oro. El guineo que brilla también es símbolo de lo desconocido, como desconocida es para Cuba la cultura norteamericana: "en lo desconocido puede haber peligro...puede que no haya nada, pero puede haber algo mortal” (31). Con esas palabras previene un ratón viejo a la "muchedumbre ratonil” (30) 
y se ofrece a ser él quien lo pruebe dada su poca utilidad para la comunidad. El sacrificio del ratón anciano es ejemplar en el sentido de la moraleja: "lo peor es a veces lo más bello” (32), sirve de lección a las generaciones más jóvenes que desdeñan la experiencia y sabiduría de sus mayores, pero también es metáfora de la precaución que debe tener el pueblo cubano en el contexto político-social de la República en el cual los Estados Unidos es el invasor, lo desconocido.

La postura del autor continúa retando el distanciamiento ideológico del narrador y su historia en el cuento “Rafaelilla y Saturnina”. Tras una sencilla narración protagonizada por dos gatas, hay una crítica explícita a los políticos, a quienes se acusa de no respetar lo prometido una vez alcanzan sus objetivos. El incumplimiento, por parte de algún gato, del acuerdo pactado con los ratones le permite al autor cotejar las similitudes entre corruptos y meninos que “como los diplomáticos y ladrones de la política, en cuanto se sienten más fuertes no respetan la fe pactada” (46). La gata Rafaelilla reúne todos los buenos atributos que deben tener los hombres sencillos: humildad, libertad de ideas y de costumbres, respeto. Saturnina en cambio representa las cualidades más bajas del hombre: vanidad, holgazanería, desprecio por “los de abajo”. Este contraste entre ambas gatas, representativo de cualidades y defectos en los hombres, le permite al autor transmitir la enseñanza al lector: "Sólo por el amor y la generosidad se puede vivir tranquilo. Sólo por eso se perdonan nuestras faltas y nuestros pecados” (53). Recurrir al uso de animales como personajes le permite al escritor proyectar cualidades y defectos del ser humano con el objetivo de insertar la lección moral y didáctica en el relato. El mensaje es, además, análogo de la situación social de la época. Con el advenimiento de la República se precisa más que nunca la colaboración entre los 
ciudadanos para consolidar la nación, para reafirmar los valores que unifican, no para fomentar distinciones.

El refranero cubano encuentra cabida en un cuento como "Picotazo, Picotazo", cuento en el que además reaparece la figura de un adulto, en este caso representada por un pájaro viejo, para alertar y guiar a los más jóvenes sobre los peligros. Como en los otros cuentos, en este hay una inserción explícita de la percepción del escritor en cuanto a la maldad: "porque la gente mala, para hacer sus maldades se junta y se olvida de sus pleitos”. La frase alecciona al lector, pero también expone el punto de vista de Bacardí. Para referirse al gato astuto que con malas intenciones procura visitar el nido, el pájaro expresa ante su desconfianza por la falsedad del felino: "te conozco, bacalo, aunque vengas disfrazao”. Con gracia e ingenio Bacardí inserta en el curso de la narración refranes típicos que le permiten al lector no sólo captar el sentido de la frase ya que lo deduce del contexto, sino que enriquece el aspecto moral de la obra mientras contribuye a fomentar un elemento tan autóctono como es el refranero. La exclusión de la "d" intervocálica en 'disfrazao', le otorga a la expresión un matiz coloquial, genuino y representativo de los distintos acentos en los que también se distingue el sello nacional.

En “La enseñanza de Papá Ratón” el autor incorpora nuevamente dichos representativos y retoma una figura mayor para que lidere y oriente a los más jóvenes. El ratón muy viejo, análogo del adulto cuya función es guiar la formación cívica, moral e intelectual del niño, debe enseñar con su ejemplo. Una de las enseñanzas del relato es presentada al lector cuando la etapa de abundancia en la que los ratones vivían en el antiguo y deshabitado caserón llega a su fin: "el paraíso ratonil se vino abajo, dejando apresados entre las ruinas a unos cuantos ratones que, aunque un poco tarde, aprendieron 
que ser ambicioso, es malo; porque como la ambición, como la avaricia, rompe el saco, haciendo que la gente pierda güiro, calabaza y miel; es decir, todo” (64). Quedan fusionadas así, en la estructura narrativa, lección y expresión. Además de alertar sobre las consecuencias de la avaricia desmedida, en este cuento se abordan temas como el sacrificio por la patria y por el bienestar del pueblo, así como las pautas a seguir para gobernar de manera justa. Si bien al ratón patriarca le corresponde ser quien se sacrifique por sus conciudadanos y que con su acción el ejemplo, el personaje de la "guayabita" representa de la generación más joven. La patria y los hermanos instan a la guayabita a buscar una alternativa. La intrepidez y determinación de la representante de la más joven contrasta con la sabiduría del ratón anciano, “capaz de dirigir a un pueblo hacia los ideales de justicia que deben guiarlo” (71). La juventud y la adultez representan las caras de dos generaciones que comparten la disposición "al sacrificio por su patria” (73) y que el escritor usa como metáforas del lector en formación a quien se le deben dar las herramientas para que luche por el bienestar de sus conciudadanos y de su nación y del lector adulto que tiene la responsabilidad de servir de guía y ejemplo al lector niño. En ambos casos, la reafirmación de la identidad cultural es fundamental para la consolidación de la nación.

Quizás el cuento más alegórico de la obra de Bacardí sea "Liborio, la jutía y el majá”. El propio título se perfila como símbolo de la fauna y el campo cubanos, cuya figura protagónica es el guajiro. Durante las primeras décadas del siglo XX, el personaje de Liborio fue, para la cultura popular cubana, símbolo del pueblo, y en particular del campesino. Creado por el caricaturista Ricardo de la Torriente, Liborio apareció por primera vez en 1900, en el periódico La Discusión. La indumentaria que distingue a 
Liborio es simbólica del campesino cubano: sombrero de yarey, guayabera blanca de hilo, pañuelo rojo al cuello y machete al cinto. Por décadas, Liborio fue el vehículo mediante el cual la broma satírica expresó el sentir y padecer del pueblo cubano, precisamente en un período en que la influencia y la presencia norteamericana se imponían en la isla. Teniendo en cuenta la función de Liborio como nombre genérico de hombre cubano, durante la República es muy probable que el Liborio creado por de la Torriente haya sido la inspiración para el personaje principal del cuento de Bacardí. De hecho, el escritor de Cuentos de todas las noches lo describe como "el guajiro que había construido su bohío de guano y yaguas. Allí con su buren de fabricar casabe, su pilón para pilar el café tostado, sus taburetes de cuero sin curtir, una olla para el ajiaco, una buena mujercita, su caballito criollo y dos perros flacos, Liborio vivía feliz e independiente” (13). El entorno de Liborio es genuinamente cubano, pero por si no bastara esa descripción el escritor acrecienta el acervo de términos distintivos del campo cubano como: el batey, el mango, los plátanos, las malangas, ñames y especialmente, el maíz. Una fecha religiosa importante como el Día de la Candelaria, el 4 de febrero que resultan del sincretismo cultural entre España y Cuba y que ha adquirido una importancia significativa en la isla también es incluida por el escritor, de manera que no quede duda alguna de la autenticidad de Liborio como guajiro cubano. La elección del nombre de Liborio para el personaje del cuento no es fortuita. El personaje creado por Bacardí además de representar al campesino cubano en toda la extensión de la palabra, cumple otra función en el cuento, como se verá a continuación.

Muy ilusionado con su cosecha de maíz, Liborio se lleva una desagradable sorpresa al descubrir que las gallinas se lo han comido y que la posibilidad de comprar un 
caballo con la ganancia de la cosecha es más remota. Siguiendo el consejo de su compadre Serapio, Liborio les pone un lazo -una trampa- para que se queden atrapadas en su intento, pero en lugar de gallinas, un majá es lo que encuentra el campesino en la trampa. La aparición del reptil supone para Liborio el inicio del cuestionamiento si un bien con un mal se paga ya que tras ser liberado del lazo, el majá se enrosca en el cuerpo de Liborio, haciéndolo su presa y dejándole libre sólo los pies para caminar. Aunque el objetivo del majá es demostrarle a Liborio que un bien con un mal se paga, la astucia de una jutía que encuentran en el camino no sólo permite que el majá quede atrapado nuevamente y Liborio recupere su libertad, sino que prueba todo lo contrario.

Además de la intención didáctica de mostrar que toda buena acción es bien recompensada y que la bondad triunfa ante la maldad, en el cuento encontramos una proyección de la conciencia cubana. La caída de Liborio en la trampa del majá es representativa de la posición vulnerable en la que se encuentra el pueblo cubano en el contexto social de la República. El Liborio creado por Bacardí también representa el sentir y sufrir del hombre de bien, del pueblo cubano que luego de haber luchado por su independencia queda sujeto a la intervención norteamericana y a la imposición de una enmienda constitucional. Es muy comprensible que después de la decepción que sufre Liborio sea necesario que la jutía le aclare que no es cierto que un bien con un mal se paga, como también lo es que después de compartir la victoria del pueblo cubano haya comprendido que la colonia continuó en la República. La literatura infantil, por estar dedicada a quienes tienen el futuro de la nación en sus manos, se torna vehículo idóneo para enfatizar lo autóctono así como para insertar la crítica social del escritor. 
Un afán didáctico y la intención explícita de reafirmar la identidad cultural imperan en Cuentos de todas las noches. La seriedad con que el autor desarrolla los temas y el valor ético que caracteriza los relatos ensalzan y reafirman la especificidad nacionalista de la obra. La figura de Liborio desaparece del acervo popular cuando culmina el período republicano. Sin embargo, no ha dejado de representar al campesino cubano en el imaginario colectivo y la existencia de un cuento como Liborio, la jutía y el majá es constancia y recordatorio del significado de Liborio en la cultura cubana.

Dentro de la literatura infantil formativa y fundacional cubana es primordial hacer referencia a la obra de Dora Alonso, la cual comienza a publicarse antes del triunfo de la Revolución y continúa ejerciendo un importante papel durante el período revolucionario. En un período en que el ambiente rural constituyó un plato fuerte Dora Alonso publica sus obras teatrales Pelusín y los pájaros (1956) y Pelusín frutero (1957), que inician, con notas criollistas, el teatro de títeres y por qué no, la representación de una identidad nacional.

Sólo cuatro obras teatrales existen de la serie de Pelusín del Monte, sin embargo, su carisma y vigor le han otorgado distinción y relevancia en la dramaturgia titiritera cubana, al punto que se le considera “títere nacional”. Pelusín del Monte y Pérez del Corcho debe su imagen al caricaturista Pepe Camejo. También conocido como el Peluso Patatuso, es un muñeco sonriente, la imagen de un niño campesino risueño con cara ancha, de cabellos claros y ojos azules. Su distintiva indumentaria es la guayabera blanca, el pañuelo rojo al cuello y el sombrero de yarey, fieles representantes del más idealizado campo cubano. Pelusín es un personaje único, pero a la vez típico y popular. Su humor criollo y su ingenio siempre le permiten lograr su objetivo: 
Pelusín: (En remedo burlón) La escuela....la escuela...! me cae más pesado ir a la Escuela...! A, e, i, o, u...Uno, dos, tres y cuatro: tres paticas tiene mi gato.

La abuela: ¡Oigan eso! ¿Cómo puede un gato tener tres patas, muchacho?

Pelusín: (Fresco) Porque se trata de un gato cojo...(Ríe y palmotea). (12)

Su abuela María Pirulí, también llamada Pirulina, es el otro personaje principal que con firmeza y dulzura dirige a los demás personajes.

Pelusín y los pájaros (1956) sitúa al lector en un escenario campestre en el que al descorrerse la cortinilla aparece la casa de madera con techo de tejas donde el niño vive con su abuela. La trama narra un episodio que tiene como personajes secundarios aves típicas de la fauna cubana, tales como el totí, el cao, la cotorra y la paloma. Esta última es víctima del tiraflechas de Pelusín, que le rompe una de sus alas. Los animales deciden castigar al niño por todo el daño que les ha hecho en su empeño de cazarlos, pero gracias a la bondad de Pirulina se evita tal resolución. Aprendida la lección, el personaje principal invita a los lectores a no cometer el mismo abuso y se despide refiriéndose a sí mismo como “su gran amigo ¡Pelusín del Monte y Pérez del Corcho! (23).

Dora Alonso, como Martí, quiere que el lector niño encuentre un aliado en la lectura, un amigo. Sin embargo, a diferencia del escritor de La Edad de Oro, no es ella quien ocupa ese papel, sino el personaje principal. Su títere es amigo que divierte, aprende y comparte, pero sobre todo, que representa los rasgos característicos de la tradición campesina cubana y los hace resaltar en un contexto histórico en que eran de fundamental importancia para combatir la influencia extranjera mientras se comenzaba a desarrollar una identidad cultural. La maestría de la escritora en el manejo de los planos lingüístico y composicional revela que desde su perspectiva el niño no es un sujeto 
subalterno, sino un individuo para quien el texto debe suponer una fuente de disfrute, de aprendizaje y de formación, exigiendo de él una lectura atenta y activa, que lo enriquezca en el plano social, cultural e intelectual. Los diálogos abuela-niño y niño-aves reflejan un modelo narrativo que no simplemente reproduce o retrata una escena campestre, sino que contribuye a la identificación de valores mientras alecciona de una manera en que al personaje se le otorga protagonismo, importancia y responsabilidad.

Tras la picardía, la gracia, las expresiones y cuartetas de Pelusín se encuentra una observación directa del modo de vida del campesino, fuente principal de inspiración para la escritora y figura recurrente en la literatura infantil cubana. El acervo lingüístico de Pelusín está repleto de vocablos que denotan cubanía y que son reflejo de la búsqueda de la identidad propia por la autora que implica la búsqueda de lo cubano. Relacionado al campo aparecen los vocablos: yeguita, bejuco, sinsonte, tomeguines, zunzún y totí; las palmas reales, los bohíos y las lomas guían el recorrido por cada página. Las ilustraciones que aparecen en el texto captan la orografía cubana, otro rasgo que evidencia la intención de la escritora de validar los rasgos más autóctonos del cuerpo físico de la nación. En el plano gastronómico platos como el boniatillo, los plátanos manzanos y las torticas de morón resaltan por su criollismo y tipicidad.

En Pelusín frutero (1957) el escenario se desplaza del campo a la ciudad mientras Pelusín prueba suerte como negociante y ansía ser un exitoso vendedor de frutas en la capital. La abuela es siempre caudal de sabiduría y voz preventiva que avisa al niño sobre los percances que pueden acontecer, pero siempre respetando su iniciativa. El paisaje ha cambiado y el lector puede notar que ahora Pelusín se desplaza en un ambiente citadino. En esta obra reaparecen las frutas del campo aunque la lección que aprende el 
protagonista resulta de su experiencia en La Habana. La yuxtaposición de campo y ciudad amplía la percepción del lector en cuanto a los distintos ambientes y gente que van moldeando la visión que tiene el protagonista de su país y de su cultura. La escritora continúa incorporando frutas tropicales como el mango, la chirimoya, y los marañones “requetecolorados”. No podía Pelusín emprender su negocio sin pegajosos pregones que se ganan la simpatía del lector. Se brinda así una representación más rica y plena de color local, de las costumbres de la época, y se reproduce además la expresión del campesino:

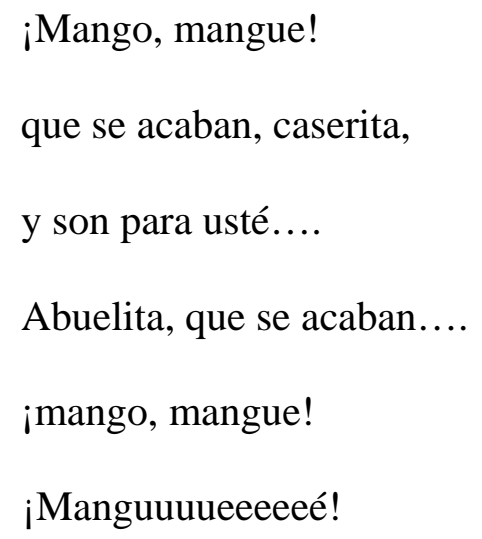

El sello de lo nacional también se encuentra en la representación de acentos, en los cuales siempre se puede apreciar la expresión individual. En las expresiones de Pelusín, representativas del campesino cubano se encuentra el sello nacional.

En las características que describen a Pelusín, además de los ambientes y situaciones que se presentan en ambas obras teatrales denotando lo autóctono, lo más raigal de la cultura cubana. Sus rasgos físicos: rubio y de ojos azules, sin embargo, coinciden con una descripción más europeizada que Caribeña. En cuanto a esta paradoja Freddy Artiles comenta que esa apariencia ha creado interrogantes en torno a la consideración de Pelusín como títere nacional, y apunta: “rubio y de ojos verdes (¿la imagen del enemigo imperialista?, ¿no debería Pelusín ser mulato, negro o al menos 
trigueño y de ojos oscuros?)”. A modo de aclaración luego expresa: “lo cierto es que Pepe Camejo, como un pequeño dios terrenal, construyó su figura a su imagen y semejanza o más bien a la de su hermana Carucha, ambos pertenecientes a la pequeña burguesía blanca de La Habana”. Es importante añadir a la aclaración de Artiles que el títere se crea en un período en el que se está consolidando la identidad nacional, en un imaginario en que todavía imperan el discurso colonial y la nueva influencia norteamericana, favorecedores de un ideal de belleza occidental, que no incluía al negro, al mulato ni al mestizo. Por lo que más que representar la imagen del enemigo imperialista, Pelusín, como títere de guante con apariencia y rasgos propios, es el resultado del ideal de su creador, pero refleja una ideología adscrita. Además, su atuendo lo legitima como cubano y le atribuye autenticidad y arraigo a las tradiciones cubanas. Son más los elementos que autentican a Pelusín que los contados rasgos que lo asocian con una imagen contraria a la que su autora quiere proyectar. Concuerdo con Artiles en que si tuviéramos que elegir un títere nacional, no podría ser otro que Pelusín por ser simbólico de la niñez y la nación cubanas, que sin embargo refuerza el auto-prejuicio.

Otras dos obras teatrales sobre Pelusín se publican posteriormente, situándose ya en el período histórico de la Revolución: El sueño de Pelusín (1963) y El teatro de Pelusín. Esta última fue estrenada en 1986 en el Teatro Nacional de Guiñol, tras ser una versión corregida y aumentada del libreto televisivo que saliera al aire en julio de 1962, como programa más de la serie Aventuras de Pelusín del Monte, que se transmitiera a lo largo de dos años. ${ }^{18}$

\footnotetext{
${ }^{18}$ Datos extraídos del artículo “Pelusín del Monte: ¿Títere nacional?” de Freddy Artiles. Publicado en la revista de cultura cubana La Jiribilla, La Habana, del 6-12 de marzo de 2010.
} 
Aunque cronológicamente pertenecen a un período histórico que poco interés ha despertado en la crítica literaria, los textos infantiles republicanos analizados en este capítulo señalizan las constantes más significativas de la cuentística republicana. El énfasis en lo autóctono, por ejemplo, está presente en todas las obras. En El pájaro de lata, Cuentos de Apolo, Cuentos de todas las noches, Pelusín y los pájaros y Pelusín frutero aparece siempre una figura representativa del campo cubano: el guajiro. Junto a él aparecen siempre otros distintivos del ambiente rural como las descripciones de varias provincias, las alusiones a frutas tropicales y una indumentaria específica, como tan detalladamente explica Dora Alonso al caracterizar a Pelusín. Así comienzan a convertirse en símbolos inconfundibles de la cultura y la identidad cubana nacional la guayabera, el sombreo de yagua, el taburete donde el guajiro contempla el campo después de una larga faena, la guardarraya por donde Apolo regresa a su bohío, el pregón que entona Pelusín al salir del campo e irse a la ciudad a vender frutas. Es rasgo distintivo también la reacción ante a la presencia norteamericana en la isla. Reacción que desde la perspectiva del escritor consiste en adoptar una postura más arraigada a lo folklórico y usarlo como mecanismo de defensa en la formación del lector niño. En Cuentos de Apolo especialmente, el concepto de inclusión socio-racial en el ideal de la nación consolida otra de las constantes en la narrativa infantil republicana. Equilibrando entretenimiento y enseñanza, las obras seleccionadas contribuyen a la edificación de una narrativa que explora el cuerpo físico de la nación, reacciona a la presencia extranjera y conceptualiza el aspecto socio-racial. 


\section{CAPÍTULO III}

\section{CONFIGURACIÓN DE LA NARRATIVA INFANTIL CUBANA POS-}

\section{REVOLUCIONARIA (1959-1989): EL NIÑO COMO CIUDADANO IDEAL Y}

\section{EMISOR POTENCIAL}

“Los niños en este país nacieron el día que triunfó la Revolución”
Fidel Castro

Desde sus comienzos, la Revolución cubana emprende un esfuerzo masivo para promover y fortalecer la educación del pueblo. Con imperioso afán, el nuevo gobierno determina propulsar la superación de los ciudadanos en el campo laboral y académico, pero sobre todo de moldear un hombre nuevo que siga los postulados revolucionarios. Los esfuerzos de inculcar una determinada filosofía de vida acorde con el nuevo sistema se centran en la generación más joven, especialmente en los niños. Escritores y pedagogos se sienten estimulados a desarrollar actividades para los niños siguiendo las pautas establecidas por el discurso político oficial. A partir de la segunda mitad del siglo XX, por lo tanto, la literatura cubana dedicada a los niños sería vehículo imprescindible para apoyar la plataforma ideológica.

Como herramienta poderosa para la construcción de la nación y la formación de los ciudadanos de distintas generaciones, la ideología ha sido clave en los textos infantiles, así como también catalizador del discurso hegemónico. En el caso de Cuba, para crear una conciencia nacional en consonancia con los ideales del hombre socialista se reorganizan las instituciones educativas y se establecen entidades gubernamentales que integren la juventud a la Revolución. Una serie de acontecimientos significativos en el 
plano sociocultural avalan la iniciativa de promover la integración de los jóvenes a organizaciones creadas por el nuevo gobierno.

El 31 de marzo de 1959 se funda la imprenta nacional. Como parte de los mecanismos culturales y educativos, surge en 1961 la Organización de Pioneros José Martí, y al año siguiente la Unión de Jóvenes Comunistas. A estos esfuerzos se suma el comienzo de la Campaña de Alfabetización en 1961, con la intención de masificar la educación e incrementar el número de potenciales lectores. Ese mismo año aparece la revista infantil "Pionero" y en 1962 se crea la Editora Juvenil bajo la tutela del escritor y pedagogo español Herminio Almendros, la cual supone el despegue de la producción literaria cubana para promover lo mejor de la literatura universal. Con el objetivo de fomentar la creación entre los autores nacionales Gente Nueva sucedería en 1968 a la Editora Juvenil. Desde de su fundación, la editorial cuyo nombre alude explícitamente al proyecto de formación revolucionario continuaría promoviendo y estimulando las iniciativas intelectuales dirigidas a los niños y a los jóvenes. En septiembre de 1985 aparece el primer número de la revista teórico-literaria “En julio como en enero” y desde entonces, aunque con cierta irregularidad, se ha continuado publicando dos veces al año e incluye textos de escritores nacionales y extranjeros. La perdurabilidad de la editorial evidencia el esfuerzo de los promotores culturales y académicos que se han comprometido con el desarrollo y la solidificación de una literatura infantil nacional que quiere reemplazar el sustrato ideológico de la literatura infantil importada.

En cada período histórico, las iniciativas de la Revolución para brindar educación a las masas han tenido una agenda ideológica consecuente con la política cultural. No sólo la proyección de los escritores infantiles es marcada por los cambios socio-políticos 
que acaecen en la isla, sino también por las exigencias y expectativas de los mismos lectores, para quienes el acontecer social y familiar no es necesariamente placentero o ideal. Por ende el establecer una conexión entre el eje sociológico del período 1959-1989 y los referentes ideo-temáticos de la narrativa infantil en estas tres décadas permite destacar cómo la función ideológica del texto influye en la construcción de nuevos ciudadanos y más generalmente de la nación.

No es este análisis el primero en hacer notar la relación entre la narrativa y los aspectos socio-políticos, en el proceso de edificar la nación. Benedict Anderson apunta que las novelas han ayudado a formar “comunidades imaginadas” y que alrededor de esas novelas y periódicos se han formado lazos entre la construcción de la nación y la comunidad impresa $^{19}$. Al referirse a las novelas fundacionales de América Latina, Doris Sommer señala que a través de la novela se establecen las naciones modernas y se proyectan sus historias ideales ${ }^{20}$. Asimismo Homi Bhabha teoriza sobre el nacionalismo como un discurso que "narra la nación”"21. Sin embargo, lo que este análisis propone es un acercamiento a la construcción de la nación cubana a raíz de su narrativa infantil y argumenta que a partir de 1959, en la tensión entre función estética e intención de adoctrinamiento, recorre una paulatina trayectoria en la que finalmente desemboca en una literatura de crítica social, que no teme romper patrones convencionales para adentrarse más en el ambiente familiar y en la realidad social. Al trazar las coordenadas

\footnotetext{
${ }^{19}$ Benedict Anderson, Imagined Communities: Reflections on the Origins and Spread of Nationalism. London: Verso, 1983, p. 30.

${ }^{20}$ Doris Sommer. Nation and Narration. "Irresistible romance: the foundational fictions of Latin America”. London: Routledge, 1994.

${ }^{21}$ Homi Bhabha. Nation and Narration, “Introduction: Narrating the Nation”. London: Routledge, 1994.
} 
temáticas que guían los textos infantiles del período concerniente a este capítulo, la adopción de un recorrido cronológico resulta idónea. Un enfoque diacrónico permite notar además cómo la mayoría de los escritores seleccionados, en mayor o menor medida, pincelan de ideología sus narraciones, mientras que otros no conciben la función edificante del texto desde el lente que requiere la política cultural oficial, sino desde el enriquecimiento que supone la indagación en las raíces.

La particularidad de iniciar una significativa producción literaria infantil posrevolucionaria la tiene el libro Navidades para un niño cubano ${ }^{22}$. Compuesta por quince cuentos, tres estampas y dos obras de teatro, la obra cuyas ilustraciones están a cargo de René Portocarrero es publicada precisamente en 1959 por la dirección General de Cultura del Ministerio de Educación en La Habana. De los escritores incluidos en Navidades, Anita Arroyo, Hilda Perera y Reneé Potts habían publicado ya durante la República. Esta particularidad hace del libro un texto doblemente ventajoso. Por un lado nos permite identificar el universo temático con relación al contexto histórico en que se sitúa. Por otro, la inclusión de escritores ya conocidos en la etapa republicana resulta idóneo para contrastar los estilos narrativos de los mismos antes y después de 1959 y así notar, en la medida de lo posible, cómo empieza a manifestarse un cambio de ideología a partir de entonces. Para cuando se emprende la campaña de alfabetización sólo dos años después, los lectores infantiles contarían con este texto en el que varias de las narraciones perfilan la intención de amalgamar la tradición criolla con el acontecer social del

\footnotetext{
${ }^{22}$ La portada y las ilustraciones del texto estuvieron a cargo de René Portocarrero. Es, hasta donde sé, el único texto infantil que el pintor y artista cubano haya ilustrado.
} 
momento, de plasmar un notable contraste entre antes y después del triunfo de la Revolución.

El campo cubano, el guajiro y sus tradiciones, la pobreza y la celebración navideña son ejes capitales en todas las narraciones de Navidades. Que el entorno campestre continúe protagonizando el escenario ya bien entrado el siglo XX no es de extrañar tomando en cuenta que desde 1900 animales típicos de la fauna cubana como la jutía y el majá, se daban a conocer en narraciones didácticas como las fábulas. Ese arraigo de componentes como el campo, la flora y la fauna cubanos es muestra precisamente de lo autóctono de la cultura cubana y por tanto de la importancia que se le concede en la formación de nuevas generaciones. Los contrastes entre campo y ciudad continúan siendo fundamentales. De acuerdo con Omar Felipe Mauri Sierra esa “edad campesina y bucólica” aparece en las producciones literarias hasta la década del setenta. El nacimiento y la descripción de festividades navideñas en el campo son temáticas centrales en los cuentos “Jesusito” y “El aguinaldo” de Anita Arroyo e “Infancia de Jesús” de Concepción T. Alzola. “La pascua campesina” de Samuel Feijoo aborda los mismos tópicos, aunque tiene un carácter más informativo y testimonial acerca de la celebración de la Nochebuena en el contexto cubano. Con abundantes detalles el escritor describe desde la comida, el ritual de servir la mesa, la organización de los guateques ${ }^{23}$ y hasta la costumbre que tiene la población rural de no comer las doce uvas a la medianoche. “Los reyes de Apolo” de Hilda Perera y “El guamo” de Reneé Potts también abordan el tema del nacimiento. Empleando los recursos clásicos de la fábula los

\footnotetext{
${ }^{23}$ Nombre con el que se hace referencia a una fiesta o celebración campesina.
} 
protagonistas que transmiten la lección moral en el texto de Potts son el guamo ${ }^{24}$, la ciguapa $^{25}$ y la guanana ${ }^{26}$. En la narración de Perera reaparece Apolo, personaje principal de los Cuentos de Apolo, obra que la escritora publicara en 1947. En los cuentos mencionados no hay temas de mayor importancia ideológica, sino rasgos representativos y distintivos del folklore campesino cubano.

“Las navidades de Higinio” de Ruth Robés Masses es, en contraste, es un cuento extenso que a pesar de girar en torno al campo y al guajiro tiene la finalidad de resaltar las diferencias entre las etapas republicana y revolucionaria. Higinio, el protagonista del cuento teme quedarse chiquito debido a la falta de proteínas y calcio. Creando un entorno narrativo en concordancia con la etapa revolucionaria, la escritora alude directamente a "la lucha contra la tiranía asesina” (33), a la solidaridad con los barbudos, con los rebeldes, quienes son presentados como hambrientos y perseguidos por las tropas de Batista. La voz narrativa irrumpe con expresión definitiva: “ahora las cosas habían cambiado” (33) y vinculando la trama a la causa del proceso social afirma que lo que importa “es aprender, ser hombre de provecho, a ser hombre de derecho" (49). En esta obra de Robés Masses hay un afán moralizante, de edificación. Sin embargo, aunque hay una continuidad de la literatura nacional precedente en cuanto a la intención de moldear al ciudadano futuro como había postulado la prosa martiana y en el sentido de ser el campo y el guajiro las figuras principales, el cuento es muestra de cómo el escritor se adhiere en gran medida al acontecer social.

\footnotetext{
${ }^{24}$ Caracol grande

${ }^{25}$ Especie de lechuza

${ }^{26}$ Tipo de ganso
} 
En “Las barbas del héroe” Anita Arroyo sigue la misma línea de compromiso político. La posibilidad de salir del bohío, la redención, la oportunidad de ser hombre, de ir a la escuela y al hospital es simbolizada por las barbas. Se rinde culto al héroe barbudo haciendo uso del más explícito adoctrinamiento. En "Reflejos”, de la misma escritora, los reyes magos se comparan con los rebeldes que “como los reyes bíblicos de Oriente portan largas, abundantes y gloriosas barbas” (133) y se ensalza el triunfo de la Revolución. La mirra y el incienso son sustituidos por imágenes cargadas de un exagerado culto a la figura del rebelde: “uniformados de verde olivo, portando las armas que nos dieron la victoria, al cuello numerosos rosarios, medallas, crucifijos, detentes y escapularios-sus joyas más preciosas y sus mejores credenciales” (134). En el texto de Arroyo el aclamo al nuevo gobierno desborda y el mensaje directo de importancia ideológica se impone: “porque el milagro ha sido providencial. Porque Dios los ha enviado a devolver la dicha a esta isla hasta hace pocos días tan infortunada cuyos sufrimientos desbordaron sus dimensiones físicas. Por poco se tiñe de sangre el mar. Los soldados del ejército rebelde, un solo ejército revolucionario -porque la Sierra Maestra o la del Escambray o la de los Organos son una misma cordillera cubana- nos han traído la estrella y la paloma de Martí” (134). En estos dos cuentos de Arroyo, así como en el de Robés Masses, la conexión entre construcción de nación y narrativa produce una articulación horizontal: los cambios socioculturales generan una intención de adoctrinamiento que influye directamente en el lector niño. Esto efecto lineal tiene una mayor repercusión considerando que esta publicación no sólo inauguraba el nacimiento de una nueva etapa sino el ciclo de lecturas de una generación que unos años más tarde alfabetizaría a los campesinos cubanos. Los mismos niños y jóvenes que leen Navidades luego educan a la 
población rural, consolidando así un proyecto de formación que produce un efecto dominó, fundamental para el nuevo organismo de poder. El texto comprometido con la agenda política es leído por el lector niño, que a su vez potencia a otro grupo de lectores igualmente susceptibles: los campesinos. En el esquema de la campaña de alfabetización, enseñanza equivale a educar la masa del pueblo, pero encaminándolo por sendas de compromiso con determinados ideales.

Como libro que recopila textos nacionales, Navidades para un niño cubano supone para el lector infantil un texto de fundación nacional, pero una mirada más atenta al mensaje que se desprende de las narraciones no sólo sugiere la distinción de posturas de los escritores en torno a la transformación social de las obras, sino que comienza a revelar una notable tensión. Los cuentos de Alzola, Potts, Perera y Feijoo ofrecen un contraste estilístico e ideológico en comparación con los de Robés Masses y Arroyo. Si bien la narrativa de los primeros se mantiene en mayor en consonancia con elementos autóctonos de la cultura y la nación cubanas reafirmando la continuidad con el eje central de la literatura nacional precedente, en las dos últimas hay un predominio del compromiso con los nuevos cambios sociales. El sentido de identidad nacional se fomenta, en el primer caso, en torno a las temáticas y elementos que ya en la etapa republicana ocupaban un puesto en los textos infantiles, mientras que en el segundo caso se adhieren a la realidad sociopolítica. En esta obra que inaugura la literatura infantil posrevolucionaria, la conexión entre iniciativas educativas y el afán ideologizante habría de resaltar la caracterización general de los primeros años de la época. Navidades para un niño cubano es precursora de un grupo de obras que autentican la expresión de 
identidad cultural e indagan en sus raíces en tanto resaltan el compromiso del creador con el entorno social.

La campaña de alfabetización no es el único acontecimiento que le confiere importancia a 1961. Ese mismo año Fidel Castro pronuncia el discurso "Palabras a los intelectuales”, que contiene la política cultural de la época y que de acuerdo con el tercer volumen de Historia de la literatura cubana, publicado por el Instituto de Literatura y Lingüística "garantizaba la libre expresión tanto formal como de contenido" (580). Sin embargo, al abordar el problema de la libertad para la creación artística, la cita no alude a una de las secciones principales del discurso, quizás la más fundamental por su sentido definitorio: "Dentro de la revolución, todo; contra la revolución, ningún derecho. Esto no sería ninguna ley de excepción para los artistas y escritores”. La revista Verde Olivo publica en 1965 El socialismo y el hombre en Cuba de Ernesto Che Guevara. En su ensayo Guevara pone muy en claro los objetivos de la Revolución pero sobre todo hace una aclaración fundamental para el intelectual que desee desarrollarse sin obstáculos: "Si se respetan las leyes del juego se consiguen todos los honores; los que podría tener un mono al inventar piruetas. La condición es no tratar de escapar de la jaula invisible” (22). Uno de los rasgos sobresalientes de esta etapa es el sentido y la conciencia del quehacer creador y la transformación social de las obras, por lo que de acuerdo con el ensayo de Che Guevara se inventa "la investigación artística a la que se da como definitoria la libertad, pero esta ‘investigación’ tiene sus límites, imperceptibles hasta el momento de chocar con ellos, vale decir, de plantearse los reales problemas del hombre y su enajenación. La angustia sin sentido o el pasatiempo vulgar constituyen válvulas cómodas a la inquietud humana; se combate la idea de hacer del arte un arma de 
denuncia” (21). La misiva que el nuevo gobierno cubano dirige a los intelectuales plantea muy bien las reglas del juego. Como un deseo que se concediera temporalmente, la libertad de expresión del intelectual encuentra dentro de la Revolución un campo para trabajar y crear. Siempre y cuando no ostente rebeldía hacia el discurso oficial el toque de queda no llega a efectuarse.

A partir de la teoría propuesta por el sociólogo francés Pierre Bourdieu sobre el campo de poder y el campo intelectual es posible profundizar en las implicaciones que los cambios culturales suponían en las condiciones de los artistas cubanos según las normativas comprendidas en Palabras a los intelectuales. Al delimitar el campo ideológico el nuevo gobierno determina la estructura y función del campo intelectual dentro del campo de poder (Bourdieu 14). En el contexto histórico que se desarrolla a partir de 1959, la función social del artista cubano será de cardinal importancia; como plantea Bourdieu "los escritores y los artistas constituyen, al menos a partir del romanticismo, una fracción dominada de la clase dominante, que en razón de su posición estructuralmente antigua está necesariamente obligada a mantener una relación ambivalente tanto con las fracciones dominantes de la clase dominante (los burgueses), como con las clases dominadas (el pueblo) y a hacerse una imagen ambigua de la propia función social” (23). Para el escritor de obras infantiles en particular, un universo de posibilidades dentro del campo intelectual le permitirá abordar problemáticas y temáticas acordes al contexto social, en la mayor parte de los casos conformes a las normativas establecidas por el campo de poder.

Si la publicación de un texto como Navidades para un niño cubano (1959) auguraba los derroteros por donde aventuraría la literatura infantil nacional, la 
publicación de Niños de Viet Nam de Felix Pita Rodríguez en 1968 confirma la continuidad y reafirmación del compromiso de la obra con el contexto social. Compuesta por viñetas relacionadas a la historia del país del Sudeste Asiático, la obra aborda con tono maniqueo los padecimientos de los vietnamitas a causa de las bombas norteamericanas mientras resalta su valentía y honor ante la crueldad de los “yanquis”. Sin escatimo en el uso de recursos que validen el contraste entre explotador y explotado, el escritor incluso utiliza publicaciones de periódicos que validen contundente y estadísticamente el asunto central: “nosotros (los Estados Unidos) hemos explotado sólo parcialmente los recursos del sudeste asiático. Y, sin embargo, el sudeste asiático produce el $90 \%$ del caucho bruto del mundo; el $60 \%$ del estaño y el $80 \%$ de la copra y el aceite de coco. Además hay allí cantidades considerables de azúcar, té, café, tabaco, frutas, especias, resinas y gomas naturales, petróleo, minerales de hierro y bauxita” $(27)^{27}$. Una alusión directa a las injusticas y los asesinatos cometidos por los americanos también aparece al referirse a las aulas escolares: "hay dos variantes antagónicas, o que nos parecen antagónicas así de pronto: las aulas al aire libre y las aulas subterráneas. Pero ambas tienen la misma motivación norteamericana: los bombardeos deliberados de las escuelas” (53). Otras viñetas establecen un paralelismo mucho más explícito entre la Cuba posrevolucionaria y Viet Nam. En “Ky y sus amigos”, por ejemplo, la Revolución le ha dado a la familia de Ky un pedacito de tierra para que lo trabaje, pero los norteamericanos han declarado ese territorio "tierra quemada” con el objetivo de impedir que los campesinos ayudaran a los guerrilleros. Desde una perspectiva parcializada, en ambos países la Revolución supone una oportunidad de progreso social mientras que el

\footnotetext{
${ }^{27}$ De acuerdo con el escritor el dato fue tomado de The New York Times el 12 de febrero de 1950.
} 
extranjero continúa representando la explotación, la influencia. Es por eso que el rechazo de un pedazo de pan que proviene de un yanqui simboliza la solidaridad de Ky con la situación de su país. “Aquí no hay edad para los héroes” es uno de los relatos de mejor trata el tema del niño-héroe. La importancia de luchar por la patria es ensalzada y aunque no se menciona el contexto cubano específicamente es posible establecer una conexión dado el enfoque político e ideológico de las narraciones. Sobre las aulas escolares de Viet Nam el lector aprende que "hay dos variantes antagónicas, o que nos parecen antagónicas así de pronto: las aulas al aire libre y las aulas subterráneas. Pero ambas tienen la misma motivación norteamericana: los bombardeos deliberados de las escuelas” (53). Hay una alusión directa a las injusticias y los asesinatos cometidos por los americanos siendo la alegada "barbarie del fascismo americano" un leitmotiv en la obra. Si el narrador observa que “en Viet Nam los aviadores del imperialismo norteamericano han declarado la guerra a los niños y las aulas son su campo de batalla mejor” (54), en Cuba los niños también son el campo de batalla idóneo y no precisamente porque se haya declarado una guerra, sino porque el niño es declarado figura principal de una lucha en calidad de ideas. Es decir, el salón de clase y el texto literario dedicado al lector niño debe, ante todo, servir como plataforma para inculcar la ideología de estado.

Si una escritora hay que en sus en sus textos para niños y jóvenes haya dejado minuciosa relación de los períodos prerrevolucionarios es Renée Méndez Capote. La República y la Colonia son los escenarios históricos de dos de las obras que la escritora publica en la década de los sesenta. En Memorias de una cubanita que nació con el siglo (1963) descuella una desbordante nostalgia al revisitar las memorias de la infancia, la etapa pasada que las nuevas generaciones sólo llegarán a conocer a través de textos como 
éste. La Habana, y en particular el barrio el Vedado, son los espacios citadinos que inician al lector en un recorrido por los aspectos más relevantes de principios de la Cuba republicana. No resaltan aquí las diferencias entre las tradiciones de antaño ni las del contexto en el que se ubica la obra. La convicción de que esos tiempos pasados existen sólo en los resquicios de las memorias matizan el aspecto autobiográfico y la escritora embarca al lector en un viaje al pasado que incluye desde los gitanos que llegaban a la ciudad hasta el titiritero que ha quedado desplazado por el cinematógrafo, la figura del yerbatero, la indumentaria de la época y las desigualdades sociales. Mediante una alternancia entre el matiz autobiográfico de la primera persona y el distanciamiento del pasado que la tercera persona permite suponer, Méndez Capote sitúa al lector en una trama que alterna entre linealidad y retorno, que con soltura y lenguaje coloquial se desplaza del auténtico helado de mantecado a los menos apetecibles batidos y frozens del contexto actual. Con carácter informativo y otorgándole a cada pasaje un aire anecdótico, Memorias de una cubanita deviene casi en crónica que se distingue no sólo por su esquema y corte costumbrista, sino por desprenderse de axiomas ideológicos en una etapa en la cual resulta casi impensable semejante posibilidad.

Muy en consonancia con los cambios sociales de la Cuba de los años sesenta y fiel a la expresión de propósitos educativos, el semanario cultural Lunes de Revolución publica Aventuras de Guille: En busca de la gaviota negra, de Dora Alonso en 1964. Bajo el pseudónimo de D. Polimita la escritora narra la historia de un adolescente entusiasmado y decidido a acompañar a su profesor y amigo en la búsqueda de un extraño ejemplar que habita en los cayos cubanos: la gaviota negra. Recorriendo y describiendo los sitios cercanos a Cárdenas, la obra de matiz documental, carácter 
ecologista e informativo se acerca a la infancia cubana en una narración lineal y una trama aventurera teñida de realismo y cubanía. A los personajes principales se suman la tía Lola y al pescador Juan Quincoce. Un afán protector caracteriza a la ocurrente tía, anquilosada ante las transformaciones que están ocurriendo mientras que la descripción del pescador resalta dedos de pies como muelas de cangrejos, así como la sencillez y la bondad del hombre que convierte las adversidades de la naturaleza y del entorno en valiosas anécdotas. En esta obra, la proyección de la praxis científica y los cambios sociales que trae el nuevo régimen coinciden con el interés de la escritora por inculcar en el lector el adeudo que tiene el pueblo con el nuevo gobierno:

Ese libro fue creado por la necesidad que sentí de referir a nuestros muchachos la hermosa aventura de la búsqueda y captura de un ejemplar de la llamada gaviota negra que, efectivamente, realicé en unión de un modesto científico y amigo, por los mismos lugares de la costa norte de Cuba que se describen. Todo resultó fácil y muy lejos de la elaboración intelectual. Entendí que los niños no disponían de un libro de esas características y sentí profundo gozo al ofrecérselo, llevándoles, con la aventura, el interés por la ciencia y el conocimiento de los logros obtenidos por el pueblo a partir del triunfo de la Revolución. ${ }^{28}$

En Aventuras de Guille hay un apartamiento del esquema clásico de las obras del género, lo que contribuye su originalidad. Sin embargo, en el carácter innovador de la obra hay que señalar que el establecimiento de una conexión entre ansias de conocimiento y

\footnotetext{
${ }^{28}$ Citado en el artículo “Centenario de Dora Alonso. Aventuras de Guille: El paso inicial” de Enrique Pérez Díaz que cubaliteraria.cu publica el 18 de marzo de 2010.
} 
descubrimiento científico y los beneficios del nuevo gobierno supone un punto de seguimiento con las obras infantiles que a partir de 1959 se habían publicado. De hecho, la construcción de un proyecto común nacional que vincule al niño como ciudadano y con los valores de la Revolución encuentra resonancia en distintos pasajes de la obra. La recién fundada Academia de Ciencias y el interés del profesor por despertar en Guille la necesidad de contribuir al desarrollo de la academia son parte del proyecto de formación de un ciudadano comprometido con la sociedad, también recién propuesto por la Revolución: "por humilde, por modesto que sea el aporte que ella reciba, lo agradecerá y le será útil” (15). En el sentido aventurero de Guille va implícita la importancia de estar al servicio de la cultura, de la ciencia. Para aplacar los temores de su tía y conseguir la tan ansiada autorización que le permita partir con Mario Brides en busca de la gaviota negra Guille se vale de un argumento en el que las transformaciones sociales tienen un gran peso: “¿No te has enterado de que el Gobierno Revolucionario construyó una autopista a lo largo de toda la península? Allí ahora puedes encontrar lo mismo que en cualquier otro poblado: cooperativas, tiendas del pueblo, escuelas, luz eléctrica, cabañas de veraneo.... ¡hasta aviones para combatir la plaga!” (23). Aunque el tono es siempre informativo y desenfadado, la presencia de un contexto histórico marcado por el cambio arroja luz sobre cómo era la vida antes y después de 1959: "nadie se ocupaba de velar ni advertir al pueblo; pero ya hoy es distinto. Todos tenemos la misma responsabilidad a la hora de cuidar las riquezas del país” (40). Si el despertar científico de la isla es ejemplificado por el profesor Mario Brides, la Academia de Ciencias y las ansias de conocimiento de Guille, la inclusión de un personaje como el pescador Juan Quinconte le permite a la escritora abordar otro contraste de índole social. Sobre su entorno Juan revela que “Aquí 
mismo nací. Mi padre y mi abuelo también fueron pescadores. Desde que abrí los ojos vi dos cosas juntas, que siempre debieron estar separadas: el trabajo y el hambre” (57). Guiado por las preguntas de Guille el pescador continúa familiarizándonos con su biografía: "nunca pude saber de letras ni de números. Y toda mi familia igual. Eché los dientes aprendiendo a escamar, a cargar redes y a tejer nasas” (58). Sin embargo, la tristeza que siente Guille al escuchar a Juan desaparece cuando una revelación irrumpe en la desafortunada descripción del pescador: “Ahora sé leer y escribir, porque durante la campaña de alfabetización nos mandaron un muchachito, más o menos de tu misma edad, que no me soltó hasta que pude escribirle una carta a Fidel” (58). Teñido de camaradería concluye el diálogo entre Guille, que también había alfabetizado en las montañas y el pescador, quien exclama: “¡Chócala compañero! ¡No en balde me caíste tan simpático!” (58). La combinación de entusiasmo juvenil y la concientización del esfuerzo colectivo en favor de una causa mayor hallan en esta obra de Dora Alonso un cause argumental que evidencia la incipiente praxis científica así como el cambio social que ocurre a partir del triunfo de la Revolución, pero con un enfoque ideológico. El discurso de la escritora en esta obra en particular es constancia de su inserción como intelectual en un campo de poder que a partir de 1959 influye significativamente en la selección de temáticas abordadas en las obras infantiles.

Siguiendo la misma línea de compromiso con el marco histórico pasado, en 1966 Renée Méndez Capote publica Dos niños en la Cuba colonial. En este caso la escritora se remonta a un período aún más distante de su contexto social y transporta al lector implícito a una Cuba en plena lucha independentista. En el seno de una familia de campo transcurren los primeros años del personaje principal, de Pelusa y de sus cuatro 
hermanos. Sirviéndose de la ambientación campestre, la escritora expone los detalles de cómo era la vida del guajiro, los modos de vida, su manera de celebrar y sus preocupaciones, las costumbres del campo, y sobre todo el trato que recibían los esclavos en las plantaciones. Hay una contraposición de percepciones sobre los derechos del hombre y sobre la esclavitud a lo largo de la obra. En la plantación del padre de Pelusa los negros son tratados “con un cariño paternal” (10). En San Francisco, a diferencia de otras propiedades vecinas no hay látigos ni cepos, ni se dan bocabajos. Un narrador omnisciente invita al lector a asomarse más de cerca a la situación imperante en la isla durante la guerra de los diez años y al hecho histórico que el 27 de noviembre de 1871 marcó la historia de Cuba para siempre: el injusto asesinato de ocho estudiantes de primer año de medicina, acusados de haber arañado la tumba de un periodista español. Dos niños en la Cuba colonial es un texto que informa y enriquece desde una óptica histórica, que forma la conciencia y el compromiso cívico y patriótico del lector no mediante letanías discursivas que alaben a un organismo de poder, sino a través de ejemplos concretos que destacan el valor de obtener una formación académica para conquistar la nacionalidad cuando la patria es esclava. Quizás sea el desenlace de la obra el grabado más verosímil del paso de la infancia a la madurez, genuina descripción del sostenimiento de inteligencia, integridad y perseverancia en el hombre de humilde origen: Y nunca, nunca a través de los años Pelusa morirá en él. En el hombre triunfador vivirá por siempre el niño campesino que por encima de todo y a pesar de no haberse dejado tomar por ella, ama su tierra, añora los olores del campo, la belleza del mar de Varadero en las noches de luna o de tormenta; para él no habrá nada comparable al trinar de los sinsontes , el 
rumor de las palmas, el sabor de la fruta madura desprendida en las madrugadas, y no habrá compañía más grata que el trato noble, entero y viril de los hombres que aran la tierra y tienen la inteligencia despierta y el alma clara del guajiro. (83)

Si trazamos una línea que cronológicamente ilustre las similitudes temáticas en la década del sesenta notamos cómo especialmente a raíz de la campaña de alfabetización y de la pronunciación del discurso “Palabras a los intelectuales” en 1961, la literatura infantil cubana transitará vertientes que en mayor o menor medida resalten el valor de elementos autóctonos o simbólicos, pero que principalmente muestren al lector el significativo contraste entre el pasado histórico y el cambio social de la época. A partir de la alusión a épocas anteriores, como el caso de las dos obras de Méndez Capote, de la analogía establecida entre el contexto cubano y el vietnamita en la obra de Pita Rodríguez o mediante el inminente compromiso cívico-social que Dora Alonso aborda en Aventuras de Guille, la construcción de la nación cubana se apoya en una narrativa que indaga en sus raíces consciente de la transformación social de la obra y que amalgama temas de importancia ideológica y reflexiones ejemplarizantes.

Al prologar Cuentos desde La Habana: últimos narradores cubanos (1996) Omar Felipe Mauri Sierra afirma que “después de 1970, con la repetición mimética de esos contenidos y la sobrevaloración de la función ideológica del arte (su carácter reflejo, su didacticismo atrófico y los códigos foráneos del realismo socialista) nuestra narrativa sufre un estancamiento que se extiende hasta 1978” (11). La publicación de Niños de la Sierra Maestra en 1972 es un ejemplo del texto al servicio de la función ideológica y el didacticismo atroz al que se refiere el crítico cubano. Compuesto por conversaciones con 
cuatro alumnos de la Ciudad Escolar “Camilo Cienfuegos” que inicialmente habían sido grabadas en cinta magnetofónica, la transcripción queda a cargo de Ambrosio Fornet. Desde una perspectiva infantil cada historia concuerda en que la Revolución es símbolo de mejoría. Según los relatos de estos niños, a partir de 1959 el cambio comienza por la posibilidad de asistir a la escuela. Clodovaldo Herrera, que antes de asistir a la escuela ayudaba a su padre a hacer carbón y venderlo cuenta que “antes de la Revolución nunca fui a la escuela. Aquí en Ciudad Escolar estoy contento. Como bien. En casa no comía mal. Desayunaba vianda frita, plátano o boniato” (11). Rafael Fonseca proviene de una familia numerosa y también vive en el campo. Su jornada de trabajo era ardua a pesar de su corta edad. Relata que se "levantaba todos los días de nochecita, como a las cinco o las seis de la mañana. Yo trabajo desde que era así de chiquitico, desde que podía con un machete y un azadón” (17). Como Clodovaldo, Rafael también desayunaba con viandas y “a la escuela nunca había ido seguido. La escuela estaba lejos. Unas veces no podía ir porque tenía que trabajar, y otras porque llovía y los caminos se anegaban” (18). Siguiendo la misma línea contrastante entre antes y después de 1959, Emilio Alvarez García, el protagonista de la tercera narración afirma que él tampoco fue nunca a la escuela por no vivir en una zona donde hubiesen colegios y por estar ayudando a su padre con las labores del campo. Refiriéndose a la venta de café que les permitía sustentarse explica cómo las cosas han cambiado para beneficio de los campesinos: "El café lo vendíamos así mismo, con cáscara y todo, a diecinueve y veinte pesos el quintal. Ahora casi todo se vende a veinticinco, y a veces a más, porque ahora es por puntos” (29). La situación de Emilio en cuanto a la educación ha cambiado significativamente según nos cuenta: "ahora trabajamos con la imprenta y los ficheros. Me han publicado una 
composición” (33). A pesar de compartir similitudes con las dos narraciones anteriores en cuanto al modo de vida en el campo, el trabajo y las costumbres, el relato de Emilio incluye un himno que su madre aprendió cuando iba a la escuela y al que ahora le “empató pedacitos de Fidel” (30). Como un signo que servilmente reitera el tributo a los mecanismos de poder y a sus líderes sin ningún cuestionamiento, el himno que ahora canta Emilio ejemplifica cómo el proyecto de formación nacional se va conformando en el campesinado de acuerdo al ideario revolucionario:

Viva Fidel que por la infancia de la tierna solicitud, quieres librarnos de la ignorancia, de las cadenas de la esclavitud.

Viva el estudio, que es meritorio ser ciudadano de una nación que, aunque pequeña de territorio, nos hará grandes de la ilustración. Héroes gloriosos que se inmolaron dieron sus vidas por conseguir conocimientos, y así sabremos ser ciudadanos del porvenir. Cuando los pueblos están conscientes no pueden nunca retrogradar. Si hacen sus hijos inteligentes, tienen por fuerza que progresar. 
Ya sí tenemos quien se devele

porque admiramos ilustración.

Gritemos todos: ¡Viva Fidel!

Con voz nacida del corazón. (30-31)

La madre de Emilio, que había tenido la oportunidad de asistir a la escuela cuando chiquita ahora comparte con su hijo, ciudadano futuro de la nación, el himno aprendido. Sin embargo, al ajustarlo al nuevo contexto social, la Revolución pasa a ser su eje central. El campesino que ha sido alfabetizado pasa ser parte integral del campo ideológico. La historia de Hilario concluye las conversaciones y comparte los mismos rasgos elementales de las anteriores: las vicisitudes del campesino con familia numerosa, la imposibilidad de asistir a la escuela, la precaria situación rural. En esta narración, sin embargo, en lugar de contrastar las etapas pre y posrevolucionarias a partir de las oportunidades de superación académica, el personaje relata los pormenores de su colaboración con el ejército. En el caso de Hilario, la importancia de los días de lucha no parece estar en que se la haya dado la oportunidad para asistir a la escuela sino en haber colaborado con el Ejército Rebelde y en ser capitán honorario del mismo desde los doce años. Con tono resoluto afirma: “cuando recuerdo a los soldados de Batista, siento una cosa que me quema por dentro...Pero al fin triunfó la Revolución” (47).

En Niños de la Sierra Maestra, como en varios de los relatos de Navidades para un niño cubano hay una tensión entre la apreciación de los elementos constitutivos de la nación y la función del discurso. La explicación de cómo hacer el carbón en el caso de Clodovaldo el carbonerito, de qué son los estrellones en el caso de Rafael y cómo se debe 
hacer una casa de guano de acuerdo a Emilio resulta fundamental para la construcción del acervo cultural. Los cuatro testimonios dan cuenta de costumbres en un determinado momento histórico, pero también de una realidad que sorprende por su significativo apego y compromiso con el contexto socio-político. Obras como Niños de la Sierra Maestra son muestra de cómo en la literatura infantil cubana sin bien ha habido un florecer a partir de 1959 en esas primeras décadas, el texto es el resultado de una labor intelectual que no confronta parámetros establecidos. Estos textos posrevolucionarios comparten con la literatura infantil precedente el afán por indagar en las raíces y los rasgos autóctonos mientras que difieren en cuanto a la transformación social de la obra y el compromiso con el discurso oficial.

Aunque un fuerte didacticismo rotula la década del setenta, en esta etapa se publican cuatro obras fundamentales para la narrativa nacional dedicada a niños y jóvenes, las cuales exploran e integran otras vías para desarrollar sus proposiciones ideoestéticas. En 1974 Onelio Jorge Cardoso publica Caballito Blanco, y en 1975 aparece El cochero azul de Dora Alonso. Ese mismo año también son publicados Costumbres de antaño y Un héroe de once años de Renée Méndez Capote y Cuentos de Guane de Nersys Felipe. De esta última escritora se publica a finales de la década Cuentos de Román Elé (1978). Las temáticas que estas obras cultivan continúan en la línea central de la literatura nacional mientras que los rasgos estilísticos y discursivos manifiestan causes originales. Dentro del período (1966-1972) se aprecian según Mauri Sierra dos vertientes de la literatura infantil tanto en prosa como en verso. La primera continúa dentro de la tradición de expresión de propósitos educativos e ideológicos, mientras que en la segunda 
se mezclan realidades y esencias con el fin de perfilar una literatura con formas novedosas de relatar.

Siguiendo el propósito educativo que la literatura para niños y jóvenes debe tener, las obras mencionadas de Onelio Jorge Cardoso y Dora Alonso exploran nuevas formas de experimentación, aunque las aproximaciones temáticas de cada uno son muy distintas. Caballito blanco agrupa seis cuentos: “Caballito blanco”, "El cangrejo volador”, "Los tres pichones”, “El canto de la cigarra”, “La serpenta”, “Pájaro, murciélago y ratón”. En la obra, Cardoso realza la importancia del mundo campestre en la identidad cultural, mientras que el lector encuentra en los cuentos la combinación armoniosa de entretenimiento y enseñanza y se familiariza con personajes como la cigarra, los pichones, el caballo, el murciélago, el pájaro y el ratón. Onelio Jorge Cardoso enfatiza en la dedicatoria del texto su compromiso con los niños de su país:

Hasta que una vez me puse a imaginar lo bonito que sería que todos los cubanos nos fuésemos a la orilla de la Isla, y con los remos en el agua, nos pusiéramos a remar y remar y nos lleváramos el país de paseo, navegando por los mares y rompiendo el agua por la proa de Maisí. Y luego llegar con la Isla a cualquier parte del mundo, echar el ancla y decir: “iQué pasa!, ¡aquí estamos los cubanos que venimos a saludar!” A todos los niños de mi patria, Cuba. (7)

El cuento que da título al libro es quizás en el que mejor estén integradas la imaginación, la fantasía y el lenguaje poético con el objetivo de sensibilizar al lector niño para que aprecie los valores éticos y estéticos. Cuentos como Los tres pichones y El canto de la cigarra destacan la importancia del valor, la determinación, la perseverancia, la confianza 
en uno mismo y el compromiso familiar. Los tres pichones anhelan ser navegantes y no se dan por vencidos hasta conseguir su propósito. En el segundo de los cuentos mencionados, la envidia, la maldad, la amistad y la solidaridad se apoderan de la trama para llevarle al lector una valiosa enseñanza. Utilizando argumentos o morales de vieja tradición, el escritor manifiesta la necesidad del individuo de emprender su propio camino y su vida, la voluntad de hacer realidad los sueños. Todas las narraciones en esta obra desarrollan exitosamente la difícil tarea de entretener formando. Caballito blanco no se ciñe a moldes de corte ideológico, sino que une vías sicológicas y muy cercanas a las de los cuentos maravillosos para perfilar nuevas formas de relatar sin desligarse de valores y temas de relevancia universal.

Bordeando lo real maravilloso en El cochero azul Dora Alonso traza un itinerario espacio-temporal a través del cual el lector le podrá dar la vuelta al mundo en un viejo coche y emprender una aventura inigualable junto a Martín Colorín y su prole de azules. Los protagonistas encuentran en su azaroso deambular a pintorescos personajes, así como lugares extraordinarios que conforman una historia llena de ingenuidad y de humor. Pipisigallo, tres simpáticos payasos con los corazones latiéndoles a la vista de todos y un pueblo que fuera de la geografía llega inusitadamente en una manga de viento guían al lector en esta fiesta de la fantasía, cargada de un gran amor por lo propio, a Cuba. Aunque esta obra de Dora Alonso es ejemplo de un estilo narrativo novedoso, lo que la situaría en la segunda vertiente a la que se refiere Mauri Sierra, el recorrido de los pintados concluye con la lección de que no hay azul como el de Varadero, que Cuba es lo mejor del mundo y "proclaman su calidad de cubanos, revolucionarios y socialistas” (94). 
El matiz ideologizante de la prosa evidencia el propósito educativo y a la vez el compromiso con el humanismo socialista en la calidad de cubano.

En Costumbres de antaño (1975) Renée Méndez Capote informa al lector acerca de las costumbres durante la República y contrasta el pasado con los progresos del presente. En la disparidad existente entre ambos períodos predomina la ideología explícita y el compromiso con el acontecer histórico de la nación. Al evaluar el pasado, un afán por adoctrinar le resta atractivo a la narración, dejando más que un recuento de las costumbres, un testimonio completamente parcializado. Aunque en el prólogo la escritora plantea que su objetivo no sólo es "hacer comprender mejor lo que tenemos que agradecerle los cubanos a nuestra Revolución” sino que "los haré reír, divertidos ante tantas ridiculeces como antes sucedían en la vida del cubano” (7), el orden de prioridad termina por situar a la Revolución en un primer plano. Hacer reír al lector es una meta supeditada a la constante crítica de la influencia americana, la reiteración del compromiso que tiene el ciudadano de la nación con el nuevo sistema. Así, una clara idea sobre las modas, la belleza y el noviazgo, entre otros temas de singular curiosidad queda en una segunda instancia y es casi siempre matizada por la subordinación de la función del arte ante la ideología. En Un héroe de once años (1975) Renée Méndez Capote aborda hechos y personalidades de las luchas independentistas y a diferencia de Costumbres de antaño la obra no está teñida de supuestos de importancia ideológica, sino relevantes a cualquier contexto por el amor patrio, la valentía y la determinación como temáticas principales. El compromiso con el acontecer histórico de la nación es de significativo peso en este caso. El texto aproxima al lector a la hazaña de un niño de once años llamado Cucho que vive en lo hondo de la manigua cubana con sus padres y hermanos. Solidarizados con la lucha 
de independencia de Cuba, el padre y los dos hermanos mayores se marchan con los insurrectos y Cucho queda a cargo de la casa, sus hermanas y su madre. Llegado el momento de confrontar a los españoles, el niño-héroe resiste estoicamente el interrogatorio cuando una bala termina con su vida e interrumpe un sentido grito de "viva Cuba libre”. Este texto de Méndez Capote, que ya cuajaba en uno de los pasajes de Memorias de una cubanita que nación con el siglo forma parte del conjunto de la obra de la escritora que destaca por cultivar ricas descripciones de períodos históricos anteriores.

El premio Casa de las Américas de 1975 lo recibe la escritora Nersys Felipe por su obra Cuentos de Guane. Guane es el nombre del pueblo en la provincia de Pinar del Río donde acontecen las historias y donde los protagonistas pasan una parte de sus vacaciones todos los veranos con sus abuelos. El libro está compuesto por catorce relatos que en un recorrido lineal familiarizan al lector con cada miembro de la familia y con la historia familiar. Este es un libro ameno, con coherencia, gracia y sentido. A través de la perspectiva del joven protagonista el lector conoce los diferentes temas familiares, como por ejemplo detalles sobre los catorce hijos que tienen los abuelos, la forma de peinarse el pelo la abuela, los cuentos del abuelo, etc. “Uno de los cuentos de abuelo” es buen ejemplo de un relato en que se alude al pasado, a la etapa prerrevolucionaria, pero se hace con mucha inteligencia y se expone el contraste por medio de ejemplos representativos: “dice el abuelo que unos políticos eran flacos y otros gordos, unos auténticos y otros liberales, que unos se ponían sombrero y otros no; pero que todos eran falsos y que ninguno era hombre honrado” (38). El cuento de abuelo narra cómo fue la presentación de uno de los políticos falsos en Guane y de cómo el pueblo, ofendido por su acción de lanzarles centavos a los niños, le insultó y le sacó a golpes: “El político hablaba. El 
pueblo lo oía. El político decía si mentiras. Y el pueblo no se las creía. Eso era un mitin” (38). En “Cosas de Guane” hay una descripción rica de lo autóctono, no solo de esa región en particular sino de toda Cuba. Hay además, una apreciación y valoración del contacto familiar, de la relación con la generación mayor (los abuelos). El contraste generacional se presenta en términos positivos y como valiosa fuente de aprendizaje de costumbres y modos para los más jóvenes: "La abuela se levanta temprano. Cruic, cruic, suena el bastidor de la cama, y la abuela suspira; luego sus pasos se oyen camino de la cocina; y al ratico, el olorcito a borra de café se cuela por toda la casa. Otros olorcitos de Guane son: el de la sopa con ají cachucha, el de la natilla quemada con plancha, el que sale de la tierra del patio doble cuando empieza a llover, y el del mamoncillo cuando está en flor” (61). Aunque un tema tan inusitado en la literatura infantil como la muerte no comienza a tratarse con más frecuencia hasta la década de los noventa, la muerte del abuelo en Cuentos de Guane es, aunque de forma muy tangencial, un precedente. La prosa de Felipe atrapa al lector desde el primer relato, convirtiendo a ésta en una de las obras que no se puede abandonar una vez comienza la lectura. La trama se nutre de lo más autóctono del entorno rural y, con un lenguaje de elocuentes descripciones, el lector de cualquier época puede abandonarse a la lectura que sensibiliza.

Aunque en su obra, Cuentos de Román Elé (1978), Nersys Felipe sí refiere el contexto histórico, la narración gira en torno a la etapa republicana. A modo de prólogo la escritora ofrece una especie de cronología sobre los períodos históricos de Cuba. Sobre la etapa precolombina describe que todos los hombres eran iguales y que vivían felices en sus cavernas. La colonia, sin embargo, es descrita como tiempo de tristeza y de abusos, de dueños con mucha riqueza y esclavos explotados. En la República, los dueños 
continuaron siendo dueños y en vez de esclavos hubo criados, de acuerdo con la escritora. Finalmente la Revolución es descrita como un tiempo que acabó con las tristezas y los abusos.

Román Elé es “alto, muy derecho y fino; con el pelo hecho de sortijas tan negras y brillantes como la piel, que parecía, por el brillo, untada en manteca de coco......Era nieto de criados, hijo de criados y criado él también” (8). Es huérfano de padres y su abuelo Calazán es su único familiar. Viven en el cuarto de maíz seco en la hacienda en que trabajan. La otra protagonista en Cruz María de los Angeles (crucita), hija y nieta de dueños que estudia en un colegio de monjas en Pinar del Río. Es interesante que una de las razones por la que está en esa escuela es para que “aprenda inglés y modales de señorita” (16). Para Román Elé los días son sin escuela y con muchas obligaciones para que el dueño lo dejara vivir con su abuelo en el cuarto de maíz seco, el viejo tuviera su almuercito, su comida y alguna ropa que ponerse. Aquí los elementos cubanos están por todas partes. En el sentido culinario aparecen el almíbar de los postres, la yuca y el boniato para los buñuelos, los tallullos. Del campo son representantes el guateque, el bongó, las claves, las maracas, el son como "De dónde son los cantantes”, décimas, canciones infantiles, como “Cuando salí de La Habana, de nadie me despedí...”. Esta obra educa sin didacticismo y con sensibilidad poética, brinda un final esperanzador, porque Román Elé se marcha de la finca y comienza a trabajar en una tabaquería y a asistir a la escuela por la noche. Es una alusión al período siguiente y a las oportunidades que tendrán todos los que no las tenían antes, sin embargo no comete el error de exponer concepciones ideológicas de la autora. 
Antonio Orlando Rodríguez sitúa al lector en una Habana allá por el año 1860 y pico en Cuentos de cuando La Habana era chiquita (1979). Pitirre, el personaje principal es “un negrito curioso y siempre andarín de toda La Habana” (9). La mamá de Pitirre es una buena negra que se ocupa de preparar dulces y luego venderlos mientras pregona. El otro personaje importante es Taita Ramón, negro y esclavo. Había sido vendido y comprado varias veces desde su llegada a Cuba, cuando era muy pequeño. Señá Francisca, la madrina de Pitirre es el otro personaje negro. No podía faltar el cuentero, Juan Pueblo, quien entre muchos valiosos relatos le cuenta a Pitirre sobre la toma de La Habana por los ingleses, aclarándole que la bandera que está en el morro es la española pero algún día estará la cubana. A través de las descripciones en estos cuentos el lector recorre las calles de la ciudad y aprende valiosos datos sobre temas términos de antaño como por ejemplo "las banquetas” que así se llamaban las aceras y los "buhoneros”, vendedores de baratijas. Esta obra instruye al lector sobre diversos aspectos de la colonia con una especial sutileza para mezclar datos de importancia histórica y elementos del refranero popular. El relato “Cuando Pitirre salió a hacer un mandado” arroja luz sobre las diferencias sociales. Cuando Pitirre se dirigía a llevarle un mandado a Taita Ramón presenció como un coche que llevaba a una niña rubia con su mamá, chocaba con una carreta y viendo que el caballo podía retroceder y golpear a la niña, Pitirre la aleja del peligro. La madre de la niña le tira a unas monedas a Pitirre, quien se queda sentado en una piedra mirando a la niña alejarse. “Cuento del cimarrón” aborda la agonía de los esclavos y mientras relata cómo Taita Ramón se escapó describe lo que es un palenque. Pero más que todo, el cuento narra la vida del esclavo, las vicisitudes y la importancia de la libertad. Taita concluye el cuento diciendo: “no era mejor acaso, morir cimarrón con 
un machete en la mano? (40). En "Cuento de cuando Jacques de Sores le prendió candela a La Habana” el lector aprende que los corsarios, a diferencia de los piratas tenían permiso para robar. Se los daba el rey de su país. Cuando asaltaban un barco tenía el compromiso de quedarse solo la mitad, la otra mitad se la daban al rey. Aprende además que la primera fortaleza que los españoles construyeron en Cuba fue el Castillo de la Fuerza. El cuento del carpintero Aponte narra la historia de quién fue Aponte y por qué se usa la frase de “eres más malo que Aponte”. Resulta que fue un esclavo libre, carpintero de oficio, que se propuso crear rebeliones de negros inculcándoles ideas de que no se conformaran con su suerte. Las autoridades españolas lo ahorcaron y expusieron su cabeza por varios días para que quedara como escarmiento. A pesar de haber sido escrito en 1979, el libro consigue transportar al lector a la etapa colonial. Valiéndose de un lenguaje sencillo pero a la altura de los retos que debe tener la narración para el lector niño, Antonio Orlando Rodríguez ofrece una obra con todos los elementos necesarios para cautivar al lector en un modo que cuando haya terminado la lectura sienta haber disfrutado de una prosa que le enseñó deleitando. Humor, entretenimiento, aprendizaje y descubrimiento caracterizan el viaje retrospectivo que representa la lectura de esta obra. El libro culmina con una lista de vocabulario con los términos que no sólo pueden suponer un reto para el lector niño sino para todo el que no esté familiarizado con palabras de la época colonial.

En 1981 Olga Fernández Valdés publica Dos días con el general. En esta narración se celebra la lucha por la libertad de Cuba, el orgullo que siente Paulino, el joven protagonista de que los mambises pasen por su pueblo, Mantua, en Vueltabajo. A través de la visión de Paulino la figura de Antonio Maceo se presenta al lector infantil. 
Concediéndole central importancia a los valores patrios y a una de las figuras más destacadas en la independencia de Cuba, la escritora concientiza al personaje principal y al lector sobre la importancia de contribuir a la lucha por la soberanía. La pérdida definitiva del padre que se ha unido a los mambises es mitigada por el orgullo que siente Paulino “de tener un papá mambí” (30). Dos días con el general es parte del grupo de obras infantiles del período cuya temática central está en función de sensibilizar al lector con hechos históricos relevantes.

Dedicado “A los niños de mi país y a la niña que fui” aparece en 1984 El valle de la Pájara Pinta de Dora Alonso. El lector inicia con la lectura de esta obra un viaje metafórico al mundo de la fantasía. Felo Puntilla, talabartero, es hombre de ideas originales y “útil en su comité” (5), su nieta Isabela, el gato Musu, que se come la uñas y por eso los ratones le han perdido el respeto, Pegaso, el caballo con alas pintado en la pared; y Cirilina la abuela de los pájaros que vivía en el Valle de la Pájara Pinta son algunos de los personajes que lo acompañan en el recorrido. La galería de personajes continúa enriqueciéndose con Quico, chico pelirrojo a quien Isabela conoce en el campo y quien le cuenta sobre el mago silvestre, Cacafú, Juan Palomo, hombre negro pequeñín de 50 años, Pepe el hermano de Juan, que es todo lo contrario, alto y rubio y Garralén, el delantal de Cirilina, que tiene cuatro bolsillos: Policlínico , Ahorro (tiene ahorrado 12 centavos para ir a un pueblo cercano a que lo laven en una lavadora automática), Repoblación Forestal (guarda semillitas que luego siembra), Abastecimiento (contiene donga, oruga y cerezas pintonas, cosas que sirven de alimento a la Pájara Pinta). Nadie sabe cómo se llega al valle, ni dónde está situado, salvo aquellos que no temen cruzar la sutil línea divisoria entre ficción y realidad. Isabela llega a casa del abuelo, quien 
preparándose para su llegada limpia la casa y lava a Pegaso, el caballo que tiene pintado en la pared. Isabela descubre que Pegaso sale a volar en las noches y regresa de madrugada, por lo que decide consultarle el caso a su abuelo. La figura del abuelo es tomada para depositar la confianza, para compartir la fantasía de la infancia. Aunque es lineal, la narración va creando una combinación de suspenso y fantasía. La solidaridad es uno de los pilares temáticos de esta obra en que resalta una lección vital: "si no perdemos el valor, hallaremos el medio de arreglar las cosas” (61). Es significativa y simbólica del gobierno cubano la historia que le cuenta Garralén a Isabela sobre el Palacio de la Reina Mandonia. La reina, cegada por la avaricia de que se le construyera un palacio, cerró las escuelas en su reino y declaró que la cultura debía terminar para que todos se dedicaran al trabajo solamente. Cuando ya casi estaba terminado el palacio una hormiga se rebeló y le dio el ejemplo a las otras, quienes se unieron a ella y lo devoraron todo. La reina Mandonia huyó llevándose el oro que le había robado al pueblo, pero al final fue descubierta y condenada a servir de sacapuntas. Las lecciones que da Dora Alonso en este texto son muy implícitas, pero a la vez, claras. Por ejemplo, para enfatizar que uno debe sentirse orgulloso de lo que es y no aspirar a imitar a nadie, Dora usa la historia del pitirre que aspira a cantar como sinsonte y que no entiende que es mejor cantar como el mejor de los pitirres que como un sinsonte de pacotilla: "pocas veces salen las cosas como uno quiere y hay que entenderlo sin ponerse majaderos” (97). El viaje al Valle de la Pájara Pinta le permite a Isabela vivir la fantasía paralelamente al mundo real. Esta es un obra estéticamente lograda, con pinceladas de humor, con enseñanzas valiosas para cualquier niño, pero que sobre todo despliega esa cubanía y ese amor por lo autóctono, tan característicos de la obra de la escritora. 
De acuerdo con la introducción que hace la editora María Teresa Sánchez Arrieta en la edición de Negrita (1984) de Onelio Jorge Cardoso, la obra del escritor puede dividirse en dos etapas: de 1940 a 1964) y de 1965 en adelante. En esa primera etapa Onelio Jorge Cardoso retrata la realidad político social del medio rural; por eso, campesinos, carboneros y pescadores son las figuras centrales de sus narraciones. En la segunda, el tema central está dado en las consideraciones de la conducta y proyección del hombre en la nueva comunidad del pueblo recién estrenado o en la ciudad. De acuerdo con la editora "Onelio Jorge posee verdadera aptitud para penetrar en la psicología de sus personajes y con un estilo que desecha las imágenes rebuscadas y las palabras altisonantes, logra el equilibrio, la seguridad y la armonía de su narración” (3) ${ }^{29}$. Negrita, que por su fecha de publicación pertenece a esa segunda etapa relata la vida de una perra que le tocó compartir con una humilde familia campesina las miserias y las alegrías durante la pseudorrepública: "La conocí hace muchos años. La llamaban Negrita y lo era de la cola al hocico. Hizo muchas cosas valientes y útiles; ya no vive, desde luego. Pero no importa; los que hacen su vida útil y valiente siempre quedan en la memoria de todos” (8). Negrita es ejemplo de justicia, coraje, independencia y dignidad. La familia, compuesta por Bruno, el padre su esposa María y dos hijos vive en la finca de don Cristóbal, quien representa al dueño abusivo y déspota, cuya prepotencia y rabia vale más que cualquier sentimiento de bondad. Una narrativa lineal y un lenguaje de precisión y exactitud en el que dominan los léxicos regionales de las zonas campesinas le brindan al lector una representación detallada del campo cubano pero también de la situación social de la época, tanto para el campesino trabajador como para el dueño de tierras. Temáticas

${ }^{29}$ Introducción a Negrita de Onelio Jorde Cardoso. La Habana, Gente Nueva, 1984. 
como la consideración a los animales, el respeto por ellos; la unión familiar, el abuso físico e injusto, las injusticias humanas y sociales son exploradas a lo largo de la obra. La explotación del campesino puede considerarse el mensaje social que realza el escritor mediante un realismo poético-crítico.

La colección de diecisiete cuentos que Enid Vian publica en 1984 con el título Las historias de Juan Yendo tiene como protagonistas a distintos animales: la abeja, la tortuga, la rata, el zunzún, el grillo Millo, pero también a Clarín el pozo, el globo Sonda y al abuelo, que por cierto fue mambí. En ellos hay un estilo sencillo, claro. No hay ninguna alusión a la Revolución ni ademán ideológico. Aquí el cuerpo de la nación se enriquece desde un acercamiento que favorece el campo, la flora, la fauna y valores como la solidaridad, la perseverancia y, el respeto por la naturaleza.

En Los chichiricú del charco de la jícara (1985), Julia Calzadilla plantea que el objetivo del libro es dar a conocer a los niños cubanos un tema central en la mitología cubana: los guijes o jigues. Los chichiricú forman parte de ellos y por lo que le explica al lector algunos datos curiosos al respecto, como por ejemplo, que se les llama con música, que son una pareja de duendecillos, y ella y él siempre andan desnudos, brillosos. El libro consta de una colección de viñetas sobre esta pareja de chichiricús, donde se incorporan los nombres de diversas áreas del país, así como la figura del guajiro que aquí se llama Cientoveinte. Hay un afán por familiarizar con el folklore, pero no hay nada de ideología. Abuelita Milagro (1985) de Antonio Orlando Rodríguez es una obra narrada en tercera persona, mediante la cual conocemos a la abuelita Milagros, al narrador y a su prima Trinidad. También aparecen personajes como el maestro refranero Benito Manso y el adivinador de la Calabaza. En la narración se destaca el campo cubano, la comida 
criolla, las tradiciones campesinas como hacer una celebración con abundante comida, invitar a vecinos y amigos, el guateque y contar adivinanzas. Los personajes viven en el campo, en una vivienda humilde. También alude a la etapa republicana. La primera indicación la encontramos cuando la abuela cuenta lo mucho que se había indignado Benito Manso cuando el dueño del ingenio de Sabanabajo fue a la escuelita y exigió que se fueran todos “porque esas tierras eran suyas y ahí no quería escuelas sino cañaverales que aumentaran sus riquezas. Por eso, cuando una madrugada le dieron candela a la escuela, el maestro dijo: 'Parece mentira, ¡con tanto machete que se dio en la manigua para acabar con estas cosas y que todos tuviéramos los mismo derechos” (16). También menciona la convicción de que "morir por la patria es vivir". La guardia rural les anuncia que deben abandonar su casa porque "estas tierras son del americano" (37). Tras deambular por los campos, sin hogar fijo, se presenta la figura del barbudo, mientras Benito Manso anuncia que al fin estamos en territorio libre. Las pinceladas de ideología que aparecen al final de la narración arrojan luz sobre la influencia del contexto social y en particular de la política cultural en la producción literaria infantil. Resulta casi imposible no contemplar las alternativas o recursos discursivos que les permiten a los escritores de este período publicar sus textos sin encontrar barreras o censuras. Más que una dicotomía entre propósitos ideológicos educativos y formas novedosas de relatar como propone Mauri Sierra, considero que hay un predominio del primer aspecto y lo que no se ajusta a las reglas del juego establecidas por el discurso hegemónico aborda temáticas de importancia histórica o de relevancia para la formación de la nación desde sus elementos más autóctonos. 
Durante los primeros treinta años a partir del triunfo de la Revolución hay un notable desarrollo en las producciones literarias dedicadas a niños y jóvenes. Siendo estos lectores emisores potenciales del discurso hegemónico, en ellos se centran todos los esfuerzos educativos y formadores de una nación que aspira a moldear al nuevo ciudadano conforme a su ideología. Nación y novela nacen a la vez, siempre que se tome la consolidación o el triunfo de la revolución como momento de nacimiento. En el caso de Cuba, los niños también nacen, de acuerdo al discurso oficial, el día que nace la Revolución. Sin embargo, en esa literatura de cardinal importancia en la consolidación nacional y en la formación de generaciones futuras, la intención de adoctrinamiento inicial va disminuyendo. Indagando en las raíces y la expresión de los rasgos constitutivos de la identidad cultural del pueblo que la sustenta, textos infantiles de este período como Negrita de Onelio Jorge Cardoso, Los chichiricú del charco de la jícara de Julia Calzadilla, Cuentos de Román Elé de Nersys Felipe, por mencionar algunos ejemplos recurren al tratamiento de temáticas no comprometidas con los cambios sociopolíticos para acercarse a los lectores sin cargas ideológicas. 


\section{CAPÍTULO IV}

\section{EL ESCRITOR, EL LECTOR Y EL ENTORNO A PARTIR DE 1990: RECORRIDO POR UN PERÍODO ESPECIAL DE MARCADA EXPLORACIÓN TEMÁTICA}

"El niño desde que puede pensar, debe pensar en todo lo que ve"

José Martí

Si en las tres primeras décadas del período revolucionario la literatura infantil cubana se enfoca principalmente en sus propósitos educativos e ideológicos, salvo algunas excepciones, a partir de la década de los noventa el giro temático y estilístico de los textos manifiesta problemáticas de índole social y aspectos inexplorados en la narrativa infantil tradicional. El didacticismo predominante en las primeras etapas contribuye a "la propagación y la total aceptación del manifiesto revolucionario" (Ocasio 56). Sin embargo, a partir de la década del noventa, los efectos del derrumbamiento del campo socialista no sólo supondrían un punto decisivo en la situación socio-económica de la isla, sino también en la creación literaria infantil. De acuerdo con el escritor cubano Luis Cabrera Delgado, esta etapa "es de tenaz persistencia creativa y variedad temática y formal” (566). En el orden temático particularmente, la narrativa nacional para niños y jóvenes de finales del siglo XX aborda cuestiones relacionadas al entorno familiar y social mientras requiere de un lector implícito activo y reflexivo, capaz de captar las estrategias textuales que le permitan explorar un mundo de situaciones complejas, que no le resulta del todo desconocido. El tratamiento de temas como el divorcio, la discriminación, las diferencias generacionales, la marginalidad, las discapacidades y hasta la muerte resalta capas más profundas de la realidad y prioriza una dialéctica con el lector a la altura del momento histórico. 
En 1960 Onelio Jorge Cardoso inaugura la vertiente infantil de su cuentística con "La lechuza ambiciosa”. Valiéndose de los recursos tradicionales de la fábula, el escritor construye una alegoría acerca del acontecer histórico que podría aplicarse al que ahora intento caracterizar: 1990-2010. En el relato de Jorge Cardoso, el pájaro sinsonte exhorta a los demás animales al levantamiento con el fin de terminar con el reinado de la lechuza: “tiempo es ya que miremos con nuestros propios ojos y no con pétalos amarillos” (172) Treinta años después, los caminos de la narrativa infantil cubana son transitados por escritores que exhortan a los lectores a examinar con mirada crítica las problemáticas que asedian el contexto social y que inevitablemente repercuten en el entorno familiar y cultural.

El comienzo de la última década del siglo XX está marcado por el llamado 'Período Especial’, que afecta los más diversos órdenes de la vida nacional: “años caracterizados por la escasez -cuando no la carencia total- de innumerables rubros de nuestra economía, que determinó en ella una crisis de magnitud no conocida en toda nuestra historia” $(587)^{31}$. Ante un colapso económico de significativa magnitud y una cuantiosa inmigración producto de la misma crisis, las preocupaciones ético-estéticas de los escritores, especialmente para los que tienen al niño como lector implícito, precisan reconsiderar su relación con el contexto social. Sin embargo, y pese a las limitaciones económicas, Cabrera Delgado observa que “durante el período de 1989 a 1999 se entregaron siete Premios de la Crítica a libros de la serie infanto-juvenil, y autores

\footnotetext{
30 Jorge Cardoso, Onelio. Cuentos completos. Ediciones Huracán. La Habana, 1965.

${ }^{31}$ Chaple, Sergio. "La vida cultural y literaria en la década”. Historia de la literatura cubana. Tomo III. Letras cubanas, La Habana: Cuba, 2008.
} 
cubanos merecieron el Premio Casa de las Américas de Literatura Infantil” (666). El desarrollo en el campo artístico-literario continúa durante esta etapa de marcada crisis en la que “a partir de 1989 los planes de publicación tuvieron que ser sustancialmente recortados, disminuidas las tiradas, modificadas las frecuencias de las publicaciones periódicas y limitado el número de sus páginas” (Chaple, 596). Varios factores contribuyen a la continuidad de ese desarrollo. En gran medida el enfoque realista ante la relación entre economía y cultura matiza de flexibilidad la política cultural ante las nuevas circunstancias. Pequeñas editoriales creadas en varias de las provincias del país permitieron que escritores principales continuaran publicando. Entre ellas destacan Vigía (Matanzas), Capiro (Villa Clara), Editorial Hermanos Loynaz (Pinar del Río), Editorial Sanlope (Las Tunas) y Ediciones Luminaria (Sancti Spíritus). Un notable esfuerzo por mantener la “manifestación personal de la necesidad del autor de expresarse libremente” marca la década del noventa (Cabrera 666). Sin embargo, la caída del campo socialista no es la única vicisitud que asedia el acontecer de la nación cubana en la última década del siglo XX.

En 1994 se produce la llamada crisis de los balseros. Para una gran mayoría de la población y, en especial para muchos jóvenes formados dentro de la Revolución, la insostenible y precaria situación económica de la isla les deja la elección de lanzarse al mar cómo única salida. A lo largo del período pos-revolucionario varias olas de emigración marcan el devenir histórico. Anteriormente, la década del ochenta estuvo marcada por otro éxodo masivo, conocido como El Mariel, que a su vez cuenta con un precedente en 1961. Poco después del triunfo de la Revolución, más de catorce mil niños y adolescentes cubanos fueran enviados por sus padres a los Estados Unidos, dando lugar 
al mayor éxodo de menores no acompañados que ha ocurrido en occidente: Operación Pedro Pan. Qué interrogantes o preocupaciones proyectan, entonces, los discursos, las estrategias y los sub-textos que componen los textos infantiles a partir de estos eventos en Cuba? Este capítulo analiza la función ideológica del texto concebido para niños y jóvenes mediante una exploración del enfrentamiento entre lector implícito y realidad social en el plano literario. Las huellas dejadas por éxodos, así como el efecto de una crisis económica sustancial evocan la lección que tantos años atrás Onelio Jorge Cardoso había brindado en su cuento "La lechuza ambiciosa”. Acorde con un contexto histórico muy distinto al de la década del sesenta, la literatura posterior a 1990 es de crítica social y se distingue por un discurso que subvierte concepciones sobre género, raza y nacionalidad, pero en el que sobre todo la cruda realidad social y sus repercusiones deben observar sin pétalos amarillos en los ojos.

A casi veinte años después de la fecha en que más de catorce mil niños y adolescentes cubanos fueron enviados por sus padres principalmente a los Estados Unidos, Hilda Perera publica Kike (1984). Por explorar temas como la partida, la separación familiar, la adaptación a un entorno desconocido y estremecedor debido a las diferencias culturales, entre otros, esta obra de Hilda Perera es precursora de los giros temáticos que comienzan a notarse en la narrativa infantil a partir de 1990. Por lo tanto debe considerarse como punto de referencia necesario al abordar el período en cuestión. Es además una obra que ha recibido poca o ninguna atención crítica y que continúa siendo desconocida para la gran mayoría de los lectores cubanos. Quizás por haber sido publicada fuera de Cuba, como casi toda la obra de Perera, o porque los hechos que acontecieron entre 1960 y 1962 tuvieron otra interpretación distinta en el imaginario 
colectivo de la isla, o simplemente porque las temáticas que explora no se ciñen a las tendencias imperantes para los escritores residentes en la isla, Kike continúa siendo una joya literaria insuficientemente explorada.

Inspirada en uno de los tantos testimonios de los que fueron parte de Operación Pedro Pan, nombre que recibió el éxodo, la escritora narra la conmovedora historia de Kike. Obligado a madurar con rapidez debido a las circunstancias y las vicisitudes que enfrenta al llegar a los Estados Unidos, Kike debe debatirse cultural y afectivamente entre el recuerdo que deja atrás y el nuevo entorno. La trayectoria del pequeño alcanza su punto de estabilidad después de haber vivido en una primera instancia con su abuelo y luego con un matrimonio que lo hospeda temporalmente y que tiene a su cargo otros niños por cuyo cuidado recibe ayuda gubernamental. En el seno de una familia americana que lo recibe tras ser separado de su hermano, Kike recibe cariño, atenciones y afecto. Sin embargo, durante la temporada que pasa con ellos también se da cuenta de cuánto se ha adaptado a un idioma y una cultura diferentes a la suya: "Me parecía que dad era mi verdadero papá y que siempre me iba a quedar con ellos. En muchas cosas me daba cuenta que no era tan cubano como antes. Ya ni siquiera extrañaba los plátanos fritos. Todavía me gustaban los frijoles negros, pero no como antes..........Ha pasado tanto tiempo, que casi se me ha olvidado la cara de mi mamá y de mi papá” (Perera 106). Veinte años después un Kike adulto se encuentra en Cayo Hueso con un grupo de voluntarios recibiendo a personas que llegan del puerto del Mariel, y el niño que habita en lo más profundo de un Kike adulto expresa: "Sólo estiro el brazo y alcanzo a poner mi mano sobre la cabeza de un niño, quizás sin padres como yo, y le digo: ¡Bienvenido hermano!” (Perera 123). El desenlace que elige Perera para su obra es, en cierto sentido, 
indicativo de la continuidad de ciclos, particularmente en el contexto cubano porque como es posible apreciar, muchos años después y por otros motivos siguen llegando cubanos a los Estados Unidos. Kike concluye con un mensaje válido para cualquier cultura. La solidaridad debe ser el eslabón principal que nos conecte con todos aquellos que estén pasando por una experiencia similar a la que pasamos y Kike se revela como un adulto que no ha olvidado su experiencia con aquellos para quienes el proceso de asimilación y adaptación apenas comienza. Si bien la etapa de desarrollo y formación del personaje principal es abordada en detalle, la obra concluye sin ofrecerle al lector muchos detalles sobre la vida de Kike como adulto. Esta particularidad puede muy bien estar asociada con el objetivo de enfatizar más que todo la etapa formativa de Kike desde una perspectiva que no está matizada por el recuerdo, sino por la inmediatez de los hechos. La sensación en la pecera ${ }^{32}$, la despedida de los padres, la ansiedad que le provoca el vuelo por ser la primera vez que viaja en un avión y la incertidumbre de dónde estarán al día siguiente le llegan al lector como ráfagas frescas al leer cada relato, como si tuviera la misma vulnerabilidad de Kike. En esta obra se perciben temáticas que distan de las expuestas en la literatura infantil de los primeros precursores. Con un tono matizado por el humor, en algunas ocasiones, y por la profunda tristeza en otras, Hilda Perera capta con una ternura palpable la voz de un niño que debe afrontar la soledad, la separación familiar, el exilio y las dudas que asaltan sus pensamientos. Kike es, en gran medida, todos los niños que vivieron la experiencia de Operación Pedro Pan, todos los que han experimentado la hibridez cultural. Es además, una obra que se adelanta, por el

\footnotetext{
${ }^{32}$ Sección del aeropuerto de La Habana a la que pasan los pasajeros cuando se despiden de sus familiares. Su similitud con el recipiente de cristal para tener los peces a la vista reside precisamente en su aspecto de pecera.
} 
tratamiento de temas como los mencionados, a una literatura infantil que hasta mucho más tarde no "sería espejo de la sociedad en que surge” (Rosell 125).

A partir de circunstancias humanas y sociales de nuevo tipo, con la llegada de los noventa una ampliación y exploración temática abre camino de los híbridos didácticos a obras en las que predomina el humor, la ironía y la fusión de fantasía y realidad, pero donde el objetivo principal es “enseñar a alguien cómo es el mundo y de qué modo sobrevivirlo mejor” (Pérez Díaz 5) ${ }^{33}$. Es decir, que para las publicaciones de este período el reto principal reside en abordar las imperfecciones del mundo y de un contexto social en particular. A esta generación de escritores, que en realidad comenzó a publicar a finales de los ochenta se les llama "novísimos". Uno de los textos más destacados de esa etapa es María Virginia está de vacaciones de Gumersindo Pacheco, Premio Casa de las Américas 1994. La segunda de una trilogía, María Virginia es una novela de aventuras, una divertida historia de amor juvenil que con desenfadado humor y espontaneidad recorre la isla desde el centro hasta la capital, para cumplir una promesa de amor. Mientras examina la realidad cubana a través de un lente irónico, pero jocoso, María Virginia ofrece una mirada costumbrista, y a la vez crítica del acontecer actual en Cuba. Cuando María Virginia López se va de vacaciones con su familia dejando solo a su novio Ricardo Armas solo, éste decide escribirle una carta: "el principio de todo fue la carta, el momento en que me senté a escribir sin sospechar que una carta fuera tan difícil” (11). Sin embargo, al enfrentar el reto de la escritura y no estar muy seguro de la dirección donde la debe enviar, Ricardo decide emprender el viaje junto a su amigo Mariano Jesusón y entregarle la carta a María Virginia personalmente. Así comienza un recorrido

\footnotetext{
${ }^{33}$ Prólogo al libro Seis caras de una infancia de Luis Cabrera Delgado.
} 
cargado de las más cubanísimas expresiones, tales como ‘fiñes’, 'asere’ y ‘sopenco’, entre otras que sólo en el argot de la isla tienen sentido, como por ejemplo, 'parar botellas’: “La botella es cuestión de suerte, pero también de habilidad. Hay numerosas formas válidas de coger botella aunque en todas lo primero que hay que hacer es olvidarse de los Moskovich y de los yipis Cuatro Puertas, pues aunque crucen vacíos tienen serios problemas para recoger extraños” (48). Otro de los temas no abordados con anterioridad que aparece en esta novela es el conflicto generacional de la adolescencia en el proceso de descubrimiento del amor y la subversión de valores totalizantes. La obra también aborda prejuicios sociales, situaciones típicas de la vida cotidiana en un pueblo de provincia y resalta algunos de los valores que la Revolución le ha inculcado a los jóvenes: "En el socialismo nadie cree en Dios. Tú no has dado eso de que creer en Dios es cosa de ignorantes y de gente supersticiosa? (125). María Virginia está de vacaciones es un ejemplo representativo de esa narrativa que inaugura un período en la literatura infantil y juvenil nacional en el que se exploran las más variadas temáticas. Mediante un discurso lleno de humor y cubanía, Sindo Pacheco acerca al lector a la cotidianidad de dos adolescentes que se aventuran a recorrer la isla enfrentado retos y desavenencias, que en última instancia fortalecen su amistad. Si bien en esta obra no se abordan temas tan fuertes como los que más adelante se atreverían a explorar los escritores de esta etapa, María Virginia sitúa al lector en un contexto muy específico en el que el habla coloquial de los adolescentes cubanos, la conflictos generacionales y la transición de la infancia a la adolescencia se posicionan en el discurso como indicadores cruciales de una narrativa que no está marcada por el didacticismo, ni por el afán de inculcar y más que como literatura, se proyecta como la vida misma. 
Desde su profesión de psicólogo, uno de los escritores que mejor les brinda a los lectores obras que invitan a la reflexión y que arrojan luz sobre asuntos rara vez abordados en textos que tienen al niño como potencial lector es Luis Cabrera Delgado. Aunque Cabrera Delgado no se confiesa a sí mismo ser un escritor para niños y considera que la literatura infantil ha de ser literatura ante todo, "la aceptación que ha tenido su obra entre el público infantil y adolescente sí nos demuestra que la infancia, además de personaje inspirador, sí es tema de creación y objeto de estudio en cada nuevo libro suyo, que nos va revelando aristas insospechadas, no solo dentro de su ya amplia obra, sino del movimiento de cubano de autores de literatura infanto-juvenil” (Díaz Pérez 7). En 1991 el escritor publica Pedrín, obra que en 1980 es mención del Premio Ismaelillo pero que por incomprensiones editoriales con relación a la discapacidad física del protagonista aparece publicada once años después. La dedicatoria a "Milagritos, quien pidió le amputaran su pierna para poder ir a la escuela” es el primer indicio de que ésta no será otra historia más con personajes convencionales. Milagritos, a quien el escritor conociera en calidad de psicólogo cuando le fue dada la labor de explicarle a la niña que su pierna debía ser amputada, es motivo de inspiración para Pedrín.

El personaje principal es un niño con una discapacidad física: “Cuando Pedrín estaba corriendo, nadie se daba cuenta, pero cuando estaba quieto le faltaba un brazo” (22). A lo largo de la narración, Pedrín, que “cuando chiquito creía que las personas solo tenían un brazo” (22), va creciendo emocionalmente “ya sabe que no es así y que él también nació como los demás; pero de todas formas sigue pensando que debe ser muy molesto tener dos brazos” (22). El niño va perdiendo sus miedos e inhibiciones, representados por un grupo de tíos que habitan la imaginaria segunda planta que existe en 
su casa. Uno de los mayores retos que enfrenta Pedrín son las miradas indiscretas y compasivas al comenzar la escuela: “Cuando Pedrín llegó a la escuela de aprender creía que todo iba a ser fácil y bonito, pero al entrar en el patio del matutino, se encontró con el Dragón de los Cien Ojos: un dragón con aspecto de un grupo de niños, !y lleno de niños! Tenía ojos por arriba, por abajo, por los lados: por todas partes. Ojos que ven lo que no hay.....!Y en ese momento veían un brazo! (28). Sin embargo, ante el valor con que Pedrín se sobrepone a los retos que aparecen en su vida según va creciendo todos los tíos se marchan. Aunque la fusión de fantasía y realismo sociológico se encuentra en todo el relato, Cabrera Delgado aborda de forma concisa y con sensibilidad, las circunstancias de un niño que aparentemente es igual a lo demás, pero que por su discapacidad física no lo es. La presencia de este personaje evidencia que ante el entorno social hay alternativas para sobrevivir mejor la realidad en lugar de evadirla. Aunque en esta obra se aprecia el ansia martiana de enseñarle al niño cuanto debe saber sin que se dé cuenta de lo que se le está inculcando, el escritor invita a reflexionar precisamente sobre lo que tanto mencionó la ensayista Mirta Aguirre, esos costados feos de la vida.

En 1996 Cabrera Delgado publica Ito, obra breve e intensa que aborda que aborda la homosexualidad, tema que en el contexto hispano continúa siendo incómodo y delicado de abordar. Con objetividad, pero ahondando en los aspectos más crueles del entorno cotidiano de Ito, Cabrera Delgado aborda las circunstancias de un niño que por tener inclinaciones peculiares debe enfrentar la marginación en el ambiente escolar y familiar. Ito, quien “tiene obsesión por las telas, las artistas famosas y los colores” (183) estudia en un internado que irónicamente se llama La Infancia Feliz. Víctima de la crueldad de otros niños que siguiendo los patrones de comportamiento de los adultos le 
aíslan y discriminan, el protagonista "se siente solo y le gustaría jugar con sus compañeros, pero las niñas no lo dejan y le dicen que él es varón, y los varones lo mandan a jugar con las hembras; por eso se entretiene siempre con su caja de fósforos de artistas famosas" (184). A la soledad e infelicidad de Ito contribuyen la ausencia de su madre muerta, de un padre que le niega el apellido y "ni siquiera vino a conocer al hijo" (192), el abuso verbal de un tío alcohólico que se averguenza de él, los castigos de la directora del internado, Miriam Malandringa y las burlas de los muchachos del barrio que lo llaman "Ito mariquita" (186). En sus pensamientos y en su abuela Ito encuentra resguardo del cruel entorno diario: "Su abuela es como una espiga de azucena. Parece endeble y frágil, !pero cómo le perfuma! A Ito le gusta peinarla, porque tiene el pelo sedoso y fino. La abuela no siempre está para el paso, pero a veces lo complace” (188). Con esta obra Cabrera Delgado no sólo expone, mediante un relato introspectivo, temas como la muerte, la intolerancia y la incomprensión, sino que ofrece una reflexión sobre "los castrantes mecanismos de autocensura y auto-agresión que el comportamiento de un entorno hostil desencadena” (Rodríguez, 217) ${ }^{34}$. Al terminar el internado Ito hace todo lo posible por ser como los demás varones: "ya se ha percatado que al caminar, los pies no deben pisar hacia dentro, y siempre que se siente, debe hacerlo con las piernas ligeramente abiertas. Se va a empezar a peinar para atrás y debe evitar por todos los medios, pensar en las musarañas” (216). Sin embargo, su transición a la secundaria parece estar también marcada por la desesperanza, pues el director, Zoilo Malachicha se ha enterado por medio de Miram Malandrina de la condición de diferente de Ito: “A los dos días de estar allí, el director le llamó a su despacho y le dijo: Tu tío tiene que venirme

\footnotetext{
${ }^{34}$ Rodríguez, Antonio Orlando. "Ito: el raro en la literatura infantil cubana”, Encuentro de la Cultura Cubana. Madrid, número 41/42, 2006, p. 106.
} 
a ver” (216). Aunque Ito se proponga cambiar, purgarse de un pecado que todavía no ha comedido por encontrarse en una edad en la que todavía la identidad sexual está en desarrollo, es posible intuir que no logrará librarse de la represión y la enajenación.

En Ito, hay, además, una explícita crítica social, aplicable al contexto de ese momento y a Cuba en general a partir de entonces. Cuando el narrador describe los rasgos de Ito expresa que además de ser lindo como una niña y muy aplicado en sus estudios, “sueña con ser maestro, pero es que también piensa, cuando sea grande, ser pintor o arquitecto, aunque está totalmente seguro que será carpetero ${ }^{35}$ de hotel” (183). Después de realizar esa afirmación sobre la futura profesión de Ito, el narrador procede a matizar el porqué: “Ito nunca ha visto una postal tan bella como la del lobby de un hotel lleno de lámparas doradas, cortinas, matas y alfombras. Y se ve, con sus ojos verde miel, de cuello y corbata, atendiendo a los huéspedes. Para llegar a ser carpetero debe estudiar mucho, pues a los hoteles lo mismo llegan chinos, que alemanes, que ingleses, y tendrá que saber muchos idiomas para poder saludarlos a todos y darles la bienvenida” (184). Sin embargo, lo que realmente plantea esa seguridad que tiene Ito de que será carpetero es la triste realidad de una Cuba en la que ha podido más la necesidad de sobrevivir que el amor a la vocación y a la profesión. Aunque la obra se publica cuando ya han pasado los momentos más críticos del Período Especial han pasado, en la isla continúa imperando la imperiosa escasez que conlleva a que tantos profesionales abandonen sus trabajos y terminen realizando otros que aunque no tienen nada que ver con su formación profesional les permiten ganarse el sustento diario. Así es que se explica que un carpeteto de hotel gane más que un maestro, un pintor o un arquitecto. El contacto con los chinos,

\footnotetext{
${ }^{35}$ Carpetero es el término que se usa en Cuba para referirse al recepcionista de un hotel.
} 
los alemanes y los ingleses equivale a recibir alguna propina en dólares, que muy probablemente equivale al salario de un mes en moneda nacional. El mensaje que se desprende de esa encubierta descripción sobre la necesidad de una buena formación académica para comunicarse en varios idiomas es indicio del porvenir de Ito. No importa qué sueñe ser, sabe que será lo que le permita sustentarse. Esa total seguridad que tiene Ito es también símbolo de una conciencia social desde la perspectiva del niño cubano, que lejos de vivir en un mundo de fantasía está muy consciente de las limitantes circunstancias que le aguardan cuando llegue a la adultez.

Ito es un claro ejemplo de lo que me gustaría llamar la particularidad cubana. Es particular no sólo porque aborda temáticas sin antecedentes en la literatura para niños y jóvenes de períodos anteriores en el contexto cubano, sino porque lo hace de una forma en que el lenguaje y la perspectiva infantil se encuentran matizados por una especie de determinismo, una fatalismo ineludible que se acepta o al menos se interpreta con resoluta madurez y sin dramatismo, sin ánimo didáctico. Al desarrollar un personaje como Ito, además de aportarle al giro temático del período novedad y diversidad, el paradigma de ciudadano modelo tan imprescindible para la construcción de la nación está sujeto a cambios. No basta con que el personaje sea un estudiante destacado y ejemplar, en su conducta y preferencias debe ceñirse a los códigos de hombría de una sociedad machista e intolerante ante lo diferente. Que Ito represente precisamente rasgos que no son acordes con ese hombre nuevo, evidencia que desde la literatura se valida y representa al otro, a ese ciudadano marginado que quiere integrarse a la sociedad y ser aceptado, pero que aun así sigue sujeto a la discriminación. Aunque Ito cuenta con personajes y una trama idóneos para causar en el lector la más melodramática impresión, 
el efecto conmovedor de la obra se logra a costa de un significativo poder comunicativo, con valor artístico y sobriedad estilística a la altura de los valores morales más elevados.

Uno de los textos que mejor ejemplifica la ampliación de temas y asuntos en torno al sincretismo religioso, las circunstancias sociales del momento, las diferencias generacionales y los conflictos familiares es Cartas al cielo (1998) de la escritora Teresa Cárdenas Angulo. Galardonada en 1997 con los premios David y Asociación “Hermanos Saíz” y en el 2000 con el Premio Nacional de la Crítica Literaria, este texto de la escritora representa, junto al resto de su obra, el panorama actual de la literatura infanto-juvenil cubana. En una entrevista que el escritor cubano Enrique Pérez Díaz le realiza, Teresa Cárdenas afirma:

“insertaría lo que hago como una literatura preocupada por la gente sobre la cual no se ocupan muchos de los que escriben para las jóvenes generaciones. Una literatura que intenta hablar de aquellos a quienes no se les suele poner el cartelito de "héroes". Escribo para lo que no aparecen en los libros casi nunca: la mujer negra, el hombre negro, la niña negra, los viejos, los niños maltratados, las mujeres violadas, los hechos más dolorosos, los secretos más ocultos, las miserias más profundas, los odios más horrendos. En mis libros están lo mal llamados “temas duros”, cosas que nos suceden y que es difícil hablar de ello” (138)

La protagonista de Cartas al cielo es uno de esos personajes que rara vez aparece en los libros: una jovencita negra y huérfana. Sumida en un caos familiar y en un mundo solitario, la protagonista intenta desenvolverse en un ambiente hostil y conflictivo, matizado por el maltrato y las humillaciones de su tía, sus dos primas Lilita y la Niña y su 
abuela. Recurrir a su madre, allá en el cielo, será el único recurso que le permita a la joven refugiarse ante tanta humillación y ante un contexto histórico en el que como señala el psicólogo infantil austriaco Bruno Bettelheim “children no longer grow up within the security of an extended family, or of a well integrated community” (11). Como resultado, la joven protagonista se inventa un mundo aledaño a su realidad cotidiana y consigue crecer espiritual y físicamente sin renunciar a su candidez y nobleza. Con una sutil precisión del lenguaje la escritora le ofrece al lector un texto epistolar que le permite contemplar la infancia desde otra perspectiva, mientras revela la fortaleza interior de una joven para combatir los sinsabores y las dificultades que caracterizan su entorno familiar. A través de la voz adolescente, la obra explora temas como las diferencias generacionales, los conflictos raciales, la incomprensión, las creencias religiosas (santería), la soledad y la grandeza del espíritu humano. Aunque en algunos aspectos la obra recuerda a la Cenicienta y es tierna pero dolorosa, un tono humorístico tiñe algunas de las cartas logrando que en más de una ocasión una sonrisa aflore en los labios del lector:

Mamá de amor:

He tenido que darme no sé cuántos baños de despojo. Abuela y tía piensan que traje la mala suerte. Llenaron mi cuarte de yerbas. Tienen un olor fuerte. Debo bañarme con ellas y echarle cascarilla y perfume al agua. El perfume está bien, pero la cascarilla se pega y deja la piel cenicienta. Un día me pinté la cara con cascarilla y alboroté mi pelo. Parecía un fantasma. Tras una puerta, esperé que abuela pasara. Entonces grité: 
“!Uuuuuuuuuuuhh!”. Se meó del susto. Cuando se le pasó, por poco acaba conmigo. 23

Una visión impactante, pero con un desenlace esperanzador contribuye a distinguir esta obra multipremiada en la que el sentido humanista de su estilo cautiva en cada una de sus páginas. En Psicoanálisis de los cuentos de hadas, Bettelheim observa con relación a la función del relato en la vida del niño que: "the fairy story begins where the child is at this time in his life and where, without the help of the story, he would remain stuck: feeling neglected, rejected, degraded” (58). En el caso de Cartas al cielo, la necesidad de la protagonista de comunicarse con su madre coincide con el inicio de la obra, cuando llega al punto de desear la muerte: "Todas las noches espero que vengas con tu papalote y me invites a morir de una vez” (7). El vínculo que las cartas le crean con su madre funciona como aliciente para sobrellevar la soledad en que transcurre su adolescencia y para explicarse la pérdida de la madre: “Mamá, no sé por qué me dejaste tan sola. Sin tus besos, sin tus abrazos, sin ese olor a margaritas que siempre tenías...A nadie le cuento lo que te extraño. Ya no puedo con tanto silencio, empezaré a escribirte” (7). Como recurso imaginario, las cartas le permiten a la protagonista aceptar su realidad, crecer física y psicológicamente y perdonar a la madre ausente: “Te perdono por los días que no estuviste conmigo y los que faltan aún. Sé que desde el cielo cuidarás de mí” (62). Al combinar las circunstancias del entorno cotidiano con el elemento onírico de las cartas, la escritora enriquece racional y emocionalmente a la protagonista. En cuanto a méritos temáticos Cartas al cielo desarrolla varios que tradicionalmente no se asociarían con la literatura infantil y que como bien observa la escritora, rara vez aparecen tratados y consigue hacerlo mediante una fusión de cotidianidad y fantasía que le permite a la 
protagonista transitar de la adolescencia a la madurez dejando atrás todo el bagaje que por tanto tiempo la fue torturando. La obra, además de formar parte del grupo de las producciones que caracterizan los noventas por el giro temático que ofrecen, contiene pinceladas de crítica social. Aunque la protagonista se inclina por la enseñanza, su prima Lilita le sugiere una profesión más lucrativa en el contexto cubano: “Quiero estudiar magisterio, pero Lilita dice que mejor me hago peluquera, que mis manos son mágicas” (59). Aunque se intente distraer al lector con la singularidad de las manos de la protagonista, la sugerencia de qué profesión elegir no consigue sino apuntar hacia un contexto social en el que la vocación queda en un segundo plano. Dentro de la problemática social que aborda la escritora, son el racismo y la marginalidad los que aparecen recurrentemente a lo largo de la obra: "Soy la niña más alta y prieta del aula” (9). Aunque desde la perspectiva de la abuela "es bueno adelantar la raza...lo mejor que puede pasarnos es que nos casemos con blancos” (10), la protagonista valida sus rasgos y facciones y subvierte el ideal de belleza estereotipado: “En la calle me encontré un pedazo de espejo. Ahora no hago otra cosa que mirarme en él. La frente, los ojos, la nariz, la boca... Sabes? He descubierto que mis ojos se parecen a los tuyos que más bonitos no podían ser, y mi nariz y mi boca son normales. No me gusta que digan que los negros son ñatos y tienen bemba. A Dios no le gustaría, seguro está bravo de oír a tanta gente criticando su obra” (13). La protagonista reafirma su color, su raza, su identidad: "Por eso no me dejo pasar el peine caliente...Prefiero hacerme moñitos, como las africanas” y añade: “algunos no saben ser negros. Dan pena” (13). 
El crítico y profesor cubano Salvador Redonet advierte que a los nuevos narradores cubanos les mueve el empeño de “conocer(se) y reafirmar(se), de indagar, de cuestionar y tratar de poner las cosas en claro, de hallar una verdad a todas las posibles, las necesarias, las de ahora” ${ }^{36}$. Cartas al cielo evidencia el empeño de una de esas narradoras que fomenta valores humanos como la aceptación, el respeto, y la integridad mediante la exploración de sus temáticas poco exploradas en la literatura para niños y jóvenes cubana hasta bien entrada la década de los noventa. Al leer esta obra de Teresa Cárdenas en la que frases como "El cariño no tiene que ver con el color” (9) recuerdan los apotegmas marcianos es casi imposible no pensar en el texto como un ejemplo de Bildungsroman. Los trastornos y cambios sociales que ocurren durante este período en la isla influyen significativamente el marco temático de obras para niños y jóvenes. Por lo tanto, los protagonistas como la joven de Cartas al cielo crecen, maduran y consiguen transitar de la adolescencia a la madurez en consonancia con esas transformaciones que afectan al propio lector.

Dentro de la narrativa de Luis Cabrera Delgado, que con más descarnado dolor transita los caminos de la narrativa cubana reciente, está es su noveleta ¿Dónde está la princesa? (2001). La muerte es el tema central de esta obra en la que no hay rastro de patetismo ni ademán de usar recursos melodramáticos. Por el contrario, Cabrera Delgado consigue tocar fibras sensibles sin causar una afectación. A diferencia de Pedrín e Ito, Germán, el protagonista de Dónde está la princesa? es un personaje que a sus cortos años enfrenta cuestiones terribles para cualquier ser humano y que a diferencia de los personajes anteriores, sí rechaza la vida. Hijo de Germán Andrés, ‘el melao’ y Gertrudis

\footnotetext{
${ }^{36}$ Redonet, Salvador. “Mi cuento por una pregunta” en revista La Gaceta de Cuba, julio-agosto de 1993, pp. 7-10.
} 
Susana, la princesa, ambos enfermos de SIDA, tras la muerte de su madre, la princesa, Germancito sólo anhela reunirse con su madre muerta y preguntarle qué hay más allá de la muerte. Otros personajes como Vidatriste y Bamboleo, cuyo verdadero nombre es Joaquín y Medellín, un distribuidor de drogas también contagiado por la enfermedad, se desarrollan en esta trama en la que Cabrera Delgado no duda en contrapesar el dolor con el humor en los viajes imaginarios de Germán, episodios de cargados de irreverencia y detalles absurdos. Bamboleo, descrito como "gordo gay” (30), quiere ser bailarín de ballet desde joven pero por tener los pies planos no le es posible e intenta suicidarse sin éxito. La sugerencia de la psicóloga que lo trató fue que matara al bailarín que había dentro de él y que para hacerlo comiera, de manera que su figura esbelta y delgada se perdiera. Así adquirió toda su manteca. Participaba en todas las fiestas y hacía el amor con todo el que se lo propusiera: "el sida es mi boleto de avión para regresar de primera bailarina” (14). La historia pudiera acontecer en La Habana o en Nueva York, Cabrera Delgado no ubica la geografía de su historia pero enfrenta el reto de crear una obra honesta con su tiempo, portavoz de asuntos como el SIDA, la segregación, la discriminación y la desesperanza. El inevitable reencuentro de Germancito con su madre viene dado por la realidad de esa muerte próxima con la que finaliza la obra. Donde está la princesa? se inscribe dentro de la literatura para niños y jovénes de inmensa transformación ideo-estética que no le teme a abordar temáticas insospechadas, a salvar lo mejor de la soledad, la miseria y la desesperación de los personajes.

Dentro de las obras de diversificación temática y formal pertenecientes a este período se encuentra País de dragones (2001) de Daína Chaviano, obra que en 1989 es galardonada con el Premio Nacional de Literatura Infantil y Juvenil "La Edad de Oro”. 
Mediante los relatos que integran el libro, la escritora no sólo recrea una remota y lejana época en la que humanos y dragones convivían apaciblemente, sino que le permite al lector viajar a través del tiempo a ese mundo sobrenatural y regresar a los orígenes. Aludiendo a la mitología universal, Chaviano realza en sus relatos el poder de la fantasía, la belleza y los valores espirituales. Antecede a cada relato una pequeña introducción relacionada al tema central del mismo. En el primer relato Tocata y fuga para una dragona, la escritora revela: "Estas son leyendas del tiempo en que los seres humanos y los dragones vivían juntos. En aquella época, las fronteras que hoy separan las naciones no existían. El mundo era un inmenso país de dragones” (13). Mediante las tramas de sus relatos, las lecciones de esperanza, el enriquecimiento personal y la perseverancia, Chaviano guía al lector, tanto niño como adulto, por derroteros que sin anclarse específicamente en la cotidianidad revelan valiosas lecciones. En todos los cuentos aparecen elementos imprescindibles e independientes del personaje y de la estructura del relato. País de dragones recupera el mundo infantil desde otra perspectiva y celebra aspectos como soñar despierto, desobedecer, ocultarle a los adultos sentimientos y pensamientos, pero hay otros temas implícitos y de alcance metafórico en estas historias que permiten una lectura adulta. Aunque valiosas lecciones educativas e instructivas se desprenden de cada historia, temas como "el encuentro con la belleza a partir del acto creativo ("Diario de un alquimista”), la dicotomía entre renunciar a una vida hogareña o entregarse a la profesión (la literatura) que requiere de una dedicación total (“La doncella de fuego”), el amor a la tierra donde se nace (“La voz de la isla”), el debate entre el deber y la ética (“Un país llamado otoño”) ${ }^{37}$, más que a la mente infantil, suponen una mejor

\footnotetext{
${ }^{37}$ Javier Gómez. “Apuntes para una biografía literaria”, www.dainachaviano.com, consultado el 10 de julio
} 
apreciación para la mente adulta. Sobre todo, por su mezcla de fantasía, mitología y magia, la escritora se aproxima al mundo infantil combinado la riqueza temática y la calidad de la prosa. Chaviano opta, además, por ofrecerle al lector un mundo que alternativo a su acontecer diario le permita ampliar su imaginario. Su obra corrobora que el campo de la creación literaria infantil no tiene fronteras ni debe temer a explorar recursos y temáticas.

Con fantasía ilimitada e hiperbólica, Eric González Conde narra las aventuras de un clan muy peculiar en La familia Tosco (2002). En la nota de contracubierta a la obra, el escritor cubano Julio Llanes observa:

“Si me preguntaran cuál es la magia, el encantamiento de estos cuentos de Eric González Conde, sin vacilación diría: la frescura, el humor cubanísimo, el desenfado maravilloso mediante el cual se aborda la realidad, transitando los caminos del absurdo y la hipérbole; la capacidad del autor de tomar elementos del refranero popular y la tradición oral campesina e insuflarles su imaginación, que los enriquece transformándolos en narraciones, viñetas, pequeñas joyas para el disfrute de niños y adultos”.

En La familia Tosco predominan los elementos que indican cubanía: "el jarro de chocolate”, “el queso con dulce guayaba” (11), la provincias Vinales, Bejucal y Madruga. Estos relatos delirantes, en los a Ileana Tosco, la hija del abuelo, el tren le pide que se case con ella y la casa de los abuelos está hecha de ladrillos y leche y permanece casi siempre cerrada porque al más mínimo intento de abrir venían los terneros, se nutren de

de 2005. 
las anécdotas y cuentos de campesinos que refieren fiestas, velorios o reuniones familiares que alimentan la fantasía de los niños. El abuelo, Amal Tosco es uno de los personajes principales en esta familia sui generis de los campos de Cuba. Un libro sin antecedentes en la literatura cubana para niños y jóvenes, en los veintiún textos que integran la obra se mezclan elementos del cuento y la novela en una línea que arranca en los años setenta y que reitera personajes y espacios en tramas con independencia argumental.

Reuniendo casi todas las temáticas que caracterizan la narrativa infantil de los noventa, Las raíces del tamarindo (2001) de Gumersindo Pachecho resulta finalista del Premio Edebé de Literatura Juvenil. En esta novela juvenil la crisis familiar se sustenta en el divorcio de los padres de Tony, el protagonista y en el hecho de que su padre esté preso. En la obra hay una búsqueda de referentes y de identidad. El apoyo de los abuelos maternos es fundamental, especialmente del abuelo, quien por ser de Canarias le brinda a Tony esa perspectiva de inmigrante justo en los días en que existe la posibilidad de una salida ilegal del país en balsa. Otra temática abordada es el despertar sexual, el descubrimiento del primer amor que en este caso resulta ser un estímulo muy positivo para Tony. El entorno social y la situación política del país se manifiestan en el desencanto de los personajes con la sociedad en que viven, con la rutina diaria que los consume. Tony y Rafael son ejemplos de una juventud desilusionada que contempla el exilio como solución a ese desencanto y que en el caso de Rafael, le causa la muerte. En el caso de Tony, el desenlace es esperanzador ya que se ha adaptado bien al preuniversitario, sabe que hará una carrera y se siente bien sin la presión de su casa. Sumido en la rutina de la escuela secundaria y en los problemas típicos de la edad, Tony 
es un adolescente que a diferencia de Ricardo, el protagonista de la trilogía María Virginia. debe afrontar situaciones de mayor complejidad: integración y desintegración social, consumo cultura y violencia intrafamiliar.

El protagonista de Terreno de nadie (2009) del escritor Ariel Ribeaux también es un jovencito negro, como en el caso de la protagonista de Cartas al cielo de Teresa Cárdenas. Sin embargo, aunque su nacionalidad no es cubana, sino haitiana, la historia de Marcel no se limita a un contexto nacional único. Emigrado a un país cuyo nombre el lector infiere que sea la República Dominica, para Marcel y sus padres el proceso de adaptación es un camino empedrado que pone a prueba la unión familiar y que en el caso del protagonista, en particular es un gran reto. A lo largo de esta conmovedora y amarga historia, el lector es testigo de cómo Marcel encuentra el amor y consigue, entre otras cosas ser aceptado por sus compañeros de escuela. Es curioso que la nacionalidad del protagonista no le sea revelada al lector hasta bien avanzada la obra. Por el uso de frases muy típicas del lenguaje coloquial en la Cuba contemporánea como "negro tenías que ser” (13), el lector tiende a pensar que en realidad el país al que se han emigrado Marcel y su familia es Cuba. Sin embargo, al adoptar una nacionalidad que no es la cubana, el escritor tiene mucha más libertad para hacer una fuerte crítica social de la isla, por lo que escoger otro país vecino, en el que se hable hasta el mismo idioma puede considerarse como un recurso para abordar desde una perspectiva analítica la realidad social de los jóvenes en Cuba. Marcel, como en el caso de la protagonista de Cartas al cielo manifiesta con determinación su postura con relación al color de su piel: "Prefiero que me digan negro a "muchacho de color”, o "moreno”, o "negrito”, o cualquier palabra engañosa de esas que utilizan para suavizar lo que realmente quieren decirte. Claro que 
soy negro, ¿y qué?” (13). Para Marcel también es necesario validar su apellido Rigó ante su profesora, quien se empeña en cambiarlo a Rigau argumentando que "es una deformación gramatical del tradicional apellido francés Rigaud prodicida por una inferencia fonética” (28).

La linealidad de la narración en Terreno de nadie, así como también la elección de narrarla la historia en primera persona pudiera percibirse como indicio de una lectura ligera. Sin embargo, por si fuera poco la inclusión de temas poco convencionales en la literatura para niños y jóvenes como el exilio y la marginalidad, Ribeaux no escatima en instruir al lector a través del narrador. Inconforme con la explicación gramatical que le ofrece su profesora, Bicicleta Anaclette, Marcel nos relate cual es verdadero origen de su apellido:

En Haití yo había recibido cursos sobre historia nacional. Ahí me enteré de que la mayoría de los haitianos éramos descendientes de africanos de diversos lugares, y de algunos franceses que se mezclaron con esos africanos. Muchos de esos franceses nos dejaron sus apellidos además del idioma. Si un francés (o un colonialista europeo, como a veces les decían) tenía esclavos (casi todos los franceses o colonialistas europeos los tenían), él le ponía a los esclavos el nombre y el apellido, que siempre era su mismo apellido. Así que a gente grandísima, y a menudo vieja, le quitaban el nombre y el apellido que traían de Africa y le ponían uno nuevo. Eso también pasó con mi familia. 29

Además de abordar el tema del racismo y la marginalidad, Ribeaux también trata la insatisfacción laboral. Aunque en esta obra a diferencia de la de Cárdenas y Cabrera 
Delgado, no es al protagonista a quien se le sugiere una profesión que poco tiene que ver con su vocación, la madre de Marcel sí encuentra muchas limitaciones para desempeñarse como maestra: "Mucho más en este país donde nadie quiere ser maestro de enseñanza primaria por lo mal que pagan, que no es mucho en comparación con otros trabajos” (15). Con rigor artístico Ariel Ribeaux nutre esta obra de los complejos problemas de la realidad contemporánea: “Una densa red de relaciones intertextuales atraviesan sus relatos y los enriquece semántica y estilísticamente. Su obra se encuentra entre lo más polémico, renovador y valioso de la literatura infantil y juvenil cubana” $(\text { Herrera } 754)^{38}$. Aunque de la obra literaria Ribeaux se destacan más títulos como En busca de un tiempo perdido (1996), El oro de la edad (1998) y Nomeolvides (2006), Terreno de nadie también confirma el surgimiento de una nueva literatura para niños en Cuba, constancia de una nueva generación de escritores en una constante búsqueda creativa.

El proceso de formación de identidad nacional en la literatura infantil y adolescente cubana posterior a 1990 está poblado por giros temáticos, una diversidad estilística y una reconsideración de las preocupaciones ético-estéticas de los escritores. Aunque la antecede una narrativa de corte tradicional en la que los hilos conductores son siempre el campo, el guajiro, las costumbres rurales y ante todo, un ánimo didáctico; la evolución de ésta literatura a partir del Período Especial supone un reto para los escritores que tienen a los niños y jóvenes como lectores potenciales. Ante los cambios sociales que acontecen es preciso establecer una conexión con el contexto social, pero también emplear recursos que le permitan al lector enfrentar la realidad en el plano literario sin

\footnotetext{
${ }^{38}$ Ramón Luis Herrera. "Ribeaux Diago, Ariel” Gran Diccionario de Autores Latinoamericanos de Literatura Infantil y Juvenil, Fundación SM, Madrid, 2010, p. 754.
} 
privarlo de fantasía y valores morales. En los escritores formados dentro de la Revolución existe un especial interés por proyectar el universo atípico dentro la literatura infantil convencional, trayendo a la luz aspectos ignorados. A partir de 1959 y especialmente en la última década del siglo XX la narrativa infantil iría recorriendo vertientes temáticas cada vez más en consonancia con los cambios socio-políticos. La Revolución se construye sobre la desacreditación del pasado y se apoya en el ideal socialista de un hombre nuevo. Sin embargo, qué queda cuando ese ideal se derrumba, cuando ante el desmoronamiento de ideologías al servicio del discurso oficial la función ideológica de la obra literaria para niños y jóvenes no es ya el objetivo primordial. Surge, entonces, una literatura que observa la realidad con distanciamiento crítico, de renovada exploración temática en la cual para que el mundo real pueda proveer información útil y a la vez interesante, la forma en que acontecen los hechos y las historias se desarrollará mediante el uso de recursos como la fantasía, el absurdo y la introspección. Los textos infantiles, por lo tanto, no sólo van a abordar el divorcio, la doble moral, la marginalidad, los conflictos generacionales, la muerte y el exilio, sino que contribuyen al proceso de formación de la nación partiendo de los retos y las vicisitudes que caracterizan el contexto social.

En 1998 Enrique Pérez Díaz publica Inventarse un amigo, obra en la que por primera vez se alude al tema de los balseros, mediante la figura del tío del protagonista. Sin embargo, aunque no relacionado a los balseros específicamente, la partida ya había sido un tema desarrollado por Hilda Perera en Kike (1984). La escritora, más allá de narrar las aventuras de un niño que llega a los Estados Unidos junto con sus hermanos y primos sin la compañía de ningún familiar siendo uno de los tantos participantes de 
Operación Pedro Pan, toca las fibras más sensibles tanto del lector niño como adulto en esta obra de exquisito. La llegada a a los noventa trae, además de todos los cambios de índole económico-social, obras como María Virginia está de vacaciones (1994) de Gumersindo Pachecho, en la que el humor juvenil y la picardía de la adolescencia se enfrentan con desafíos que ponen a prueba la amistad, el respeto a los mayores y la perseverancia con el objetivo de cumplir una promesa de amor. A partir de obras como ésta el lector infantil y juvenil va a encontrarse con diálogos que le son muy familiares por la referencia a provincias específicas de la isla, por el reconocimiento de expresiones coloquiales cotidianas, pero principalmente por ser una literatura que es en esencia, un conjunto de experiencias que son reconocibles para el lector, que le presenta la realidad con un matiz picaresco, aventurero, ingenioso. Abordando temas como las discapacidades físicas y la identidad sexual, obras como Pedrín (1991) e Ito (1996) del escritor Luis Cabrera Delgado contribuyen en gran medida a la diversificación temática de este período. Por su parte, la escritora Teresa Cárdenas Angulo sorprende al público lector con su obra Cartas al cielo (1998). Con una prosa poética y cargada de humanismo la escritora construye un Bildungsroman en el que la protagonista consigue superar el desamor, la soledad y la discriminación. Refugiándose en las cartas que le escribe a su madre muerta, la protagonista de Cartas al cielo se sobrepone a los sinsabores de la realidad cotidiana. La fantasía que desborda de obras como País de dragones (2001) de Daína Chaviano y La familia Tosco (2002) de Eric González Conde invita al lector a aventurarse por senderos muy apartados del didacticismo mientras que Las raíces del tamarindo (2001) de Gumersindo Pachecho y Terreno de Nadie (2009) de Ariel Ribeaux exploran el enfrentamiento de los adolescentes nuevas circunstancias ya sean en un país 
extranjero o en un contexto nacional en el que la transición de la niñez a la adolescencia supone un duro despertar a la realidad. Las obras analizadas en este capítulo no sólo proyectan un discurso que requiere de la participación de un lector activo dispuesto a desprenderse de los patrones tradicionales de la literatura infantil y juvenil, sino que abordan complejas temáticas que enriquecen el panorama nacional aportándole una alta dosis de contemporaneidad y crítica social. 


\section{CONCLUSIONES}

El presente estudio se ha centrado en analizar el contraste que existe entre la narrativa infantil cubana pre y pos-revolucionaria prestando especial atención a la función ideológica del texto en diferentes contextos históricos. Durante el siglo XIX la estricta función pedagógica de las obras para niños y jóvenes se manifiesta claramente en la producción de textos escolares y silabarios. Sin embargo, y aunque conteniendo siempre una lección moral, las fábulas cubanas van a acentuar el humorismo y la inclusión de animales típicos de la fauna isleña. Teniendo muy en cuenta que La Edad de Oro (1889) de José Martí marca un hito en la narrativa infantil cubana, este estudio parte de su análisis en el capítulo uno para explorar el proyecto de edificación moral que propone el escritor para moldear al ciudadano futuro desde una temprana edad y para hacerlo sin que parezca que se le está indoctrinando. Representativa de la vertiente didáctica que hasta la década del ochenta estaría tan presente en la literatura para niños y jóvenes, esta obra de Martí edifica simultáneamente al lector niño y a la nación y comparte muchos puntos, desde una perspectiva ideo-estética con los postulados del pedagogo brasileño paulo Freire. Para una mejor comprensión de los giros temáticos y las nuevas formas para relatar que más tarde distinguen la narrativa infantil nacional, es de cardinal importancia partir de La Edad de Oro.

Con la llegada de la República en 1902 comienza un período de marcada singularidad para la historia de Cuba. Sin embargo, poco énfasis crítico se ha hecho en la narrativa infantil de esta etapa, por lo que en el segundo capítulo de este estudio se analizan algunos de los textos republicanos más relevantes. Aunque desde la postura de algunos escritores infantiles cubanos "no podemos hablar de una literatura para niños y 
jóvenes en desarrollo hasta después del triunfo de la Revolución” (Elizagaray 130), un retorno a la etapa republicana no sólo permite hallar una literatura infantil en la que destacan las representaciones de una identidad nacional incipiente, el reflejo de tensiones sociales de la época y una corriente discursiva autóctona, sino además un punto de referencia y apoyo para desarrollar un criterio mejor fundamentado y completo sobre la literatura infantil que se desarrollará durante la Revolución.

La transición de la República (1902-1958) a la Revolución (1959) ocasionó cambios culturales, sociales y políticos que perfilaron y moldearon la creación de una identidad nacional. Las variadas circunstancias sociales van a matizar, más que nunca, los objetivos del escritor, así como su particular acercamiento a la definición de cubanidad: “en épocas distintas y con diversos objetivos políticos, varios escritores, críticos e historiadores cubanos de los siglos XIX y XX han insistido en la singularidad de su literatura nacional y han definido la noción de "cubanidad” de múltiples modos" (Llorens 7). Después de 1959 la producción literaria infantil cubana emprende un ininterrumpido ascenso motivado por diversos factores socio-culturales. En las publicaciones literarias infantiles pertenecientes al período revolucionario abundan la diversidad de temáticas, tonos y estilos narrativos que reflejan el contraste generacional de sus escritores. Los rasgos distintivos de cada época a partir de 1959 se hacen más notables en la medida que nos distanciamos de la emblemática fecha. A partir de la segunda etapa (1966-1972), se observa una diversificación temática que irá fomentando el uso de la literatura infantil con otro objetivo que no sea el de enunciado didáctico. La fundación del Instituto Cubano del Libro y la editorial Gente Nueva en 1967 promueve esa literatura en la que ya se perfilaban rasgos distintivos. La creación literaria infantil 
producida durante la etapa formativa denota una estrecha relación entre texto y contexto, se enfatiza la función pedagógica de la obra así como la intensidad testimonial e ideológica. Los valores estéticos de la obra quedan subordinados con frecuencia y la intención política se antepone a la imaginación poética. Los más valiosos propósitos de esos textos pertenecientes a la primera etapa sucumben al excesivo realismo. Con un notable nivel cualitativo, la literatura de este período realza además de los temas tradicionales, lo criollo, lo caribeño, la historia y las fábulas, la ciencia ficción y en especial, el folclor campesino. A principios de la década de los ochenta, abundan los abuelos que conciben la infancia en un tono afable y de añoranza, pero también mágico, y esto los diferencia de sus predecesores, quienes proyectaban por lo general una imagen inflexible y distante del mundo infantil: "Los adultos que aparecen en la mayoría de libros infantiles no pueden librarse de su manera de ser y son incapaces de cualquier cambio o desarrollo" (Lurie 11). En Abuelita Milagro de Antonio Orlando Rodríguez los abuelos dejan de representar problemas de la tercera edad para invadir al lector con su sabiduría y el equilibrio necesario en las relaciones sociales y familiares del niño.

Se consolida la profundidad y la creatividad, mientras que una nueva generación de creadores asciende. Dentro de los mejores momentos de la serie infantil cubana de este ciclo se destaca la voz íntima del narrador en lugar de la voz aleccionadora del maestroamigo y se produce una expansión de la literatura hacia una dimensión psicológica o interior que le permite al niño indagar en sus relaciones con la sociedad, la familia y el entorno. Las publicaciones posteriores a 1990 ofrecen un giro significativo en cuanto a temáticas, estética y propósitos que distan del concepto tradicional de la literatura dedicada a niños y jóvenes. En los escritores formados dentro de la Revolución existe un 
especial interés por proyectar el universo de la atípica niñez cubana, trayendo a la luz aspectos ignorados en la literatura infantil tradicional: el divorcio, la doble moral, la marginalidad, los conflictos generacionales, etc.

La trayectoria de la literatura infantil cubana no sólo refleja sus distintos períodos y sus figuras más destacadas, sino que las nuevas creaciones literarias dentro de este género manifiestan la relación entre lo subjetivo y lo objetivo, así como la complejidad de un discurso que se ha universalizado por sus temas y estructuras. Los autores contemporáneos insisten en teñir su lenguaje con sus anhelos, expectativas y experiencias. 


\section{BIBLIOGRAFÍA}

Alonso, Dora. El cochero azul. La Habana: Editorial Gente Nueva, 1975.

---Pelusín del Monte: Teatro de títeres. Matanzas: Ediciones Vigía, 2000.

---Las aventuras de Guille. La Habana: Gente Nueva, 1969.

Angvik, Birger. "La teoría de la novela de Mario Vargas Llosa y su aplicación en la crítica literaria”. La narración como exorcismo. Mario Vargas Llosa, obras (1963-2003). Lima: FCE, 2004.

Arroyo, Anita. El pájaro de lata. Río Piedras: San Juan, 1973.

Balmaseda, Francisco Javier. Fábulas Morales. Habana: Próspero Manssana, 1858.

Behar, Sonia. La caída del hombre nuevo: narrativa cubana del período especial. Miami, 2007.

Benjamin, Walter. La literatura infantil, los niños y los jóvenes. Buenos Aires: Nueva Visión, 1989.

Bourdie, Pierre. Campo del poder y campo intelectual. Argentina: Ediciones Tucumán, 1983.

Bettelheim, Bruno. The uses of enchantment. New York: Alfred A. Knopf, 1976

Cabrera Delgado, Luis. Seis caras de una infancia. La Habana: Gente Nueva, 2012.

---¿Dónde está la princesa? La Habana: Gente Nueva, 2001.

Cárdenas, Teresa. Cartas al cielo. La Hababa: Gente Nueva, 2013.

Cardoso, Onelio Jorge. Negrita. La Habana: Gente Nueva, 1984.

---Caballito blanco. La Habana: Gente Nueva, 1974.

Chambers, Aidan. "El lector en el libro.” Un encuentro con la crítica y los libros para niños. Ed. Banco del Libro.Venezuela: Editorial Arte, 2001. 95-126.

Chaviano, Daína. País de dragones. Madrid: Espasa Calpe, 2001.

Che Guevara, Ernesto. El socialismo y el hombre en Cuba. Venezuela: Fundación Editorial El perro y la rana, 2009. 
Cunnigham, Hugh. "Evolución de una ideología de la infancia en la clase media, 15001900”. Giros y reveses: representaciones de la infancia a través de la historia. Ed. Arte. Venezuela: Banco del libro, 2004. 29-63.

De la Paz, Luis. "Rostros en la narrativa cubana". Centenario de la República cubana 1902-2002. Eds. William Navarrete y Javier de Castro Mori. Miami: Ediciones Universal, 2002. 317-336.

De la Torre, Rogelio A. "La educación en la Cuba republicana". Centenario de la República cubana 1902-2002. Eds. William Navarrete y Javier de Castro Mori. Miami: Ediciones Universal, 2002. 193-212.

Diego, Eliseo. “Una ojeada cubana a la literatura infantil” Revista de la biblioteca nacional 1

(January-April 1970): 83-91.

Elizagaray, Alga Marina. En torno a la literatura infantil. Habana: UNEAC, 1975.

---. “La Edad de Oro: El gran clásico infantil de nuestra época.” Acerca de La Edad de Oro. Ed. Salvador Arias. La Habana: Letras Cubanas, 1980. 294-308.

---. Niños, autores y libros. La Habana: Gente Nueva, 1981.

Eagleton, Terry. Ideology: An Introduction. London: Verso, 1991.

Enriquez Ureña, Max. Panorama histórico de la literatura cubana. Volumen 2. México: Max Enríquez Ureña, 1963.

Felipe , Nersys. Román Elé. La Habana: Casa de la Américas, 1978.

---Cuentos de Guane. La Habana: Casa de las América, 1976.

Fernández, Damián, and Madeline Cámara Betancourt, eds. Cuba, the Elusive Nation: Interpretations of National Identity. Gainsville: University Press, 2000.

Fernández, Olga. Dos días con el general Antonio. La Habana: Gente Nueva, 1981.

Freire Paulo and Donaldo Macedo. Literacy: Reading the Word and the World. Great Britain: Routledge and Kegan Paul Ltd, 1987.

--- Sobre la acción cultural. Chile: ICIRA, 1970.

Fornet, Ambrosio. Niños de la sierra Maestra. La Habana: Gente Nueva, 1972.

Fornet, Jorge y Carlos Espinosa Domínguez. Cuento cubano del siglo XX. México D. F: Fondo de Cultura Económica, 2002. 7-28. Impreso 
Gallego, Alfonso Emilia. Por Qué Y Para Quién Se Escribe "la Edad De Oro. La Habana: Editorial Academia, 1999.

García Marruz, Fina. “La Edad de Oro”. Temas Martianos por CintioVitier y Fina García Marruz. La Habana: Biblioteca Nacional José Martí. Departamento Colección Cubana, 1969, pp 292-304.

---. "La Edad de Oro”. Acerca de La Edad de Oro. Ed. Salvador Arias. La Habana: Letras Cubanas, 1980. 192-209.

Guerrero, Teodoro. Lecciones de mundo. Habana: SM, 1864.

Güell, y R. J, and M Costáles. Aguinaldo Para Los Niños. Habana: Oficina del Faro Industrial, 1846.

Goldin, Daniel. “La invención del niño. Digresiones en torno a la historia de la literatura infantil y la historia de la infancia.” Lectura y Vida Jun. 2001: 619. Impreso

Llorens, Irma. Nacionalismo y literatura. Constitución e institucionalización de la "República de las letras cubanas. Lérida, España: Asociación Española de Estudios Literarios Hispanoamericanos, 1998.

Mañach, Jorge. Historia y estilo. La Habana: Editorial Minerva, 1944.

Martí, José. Obras completas. T. 20, La Habana, Editorial Nacional de Cuba, 1965, pp. 146-148.

---. La Edad de Oro. La Habana: Pueblo y Educación, 1995.

Mauri Sierra, Omar. Cuentos desde La Habana: últimos narradores cubanos. Alicante: Aguaclara, 1996.

Méndez Capote, Renée. Memorias de una cubanita que nación con el siglo. Barcelona: Argos Vergara, 1984. La Habana: Gente Nueva, 2002

---Un héroe de once años. La Habana: Gente Nueva, 2002.

Ocasio, Rafael. "La Revolución cubana y su literatura infantil." Confluencia: Revista Hispanica de Cultura y Literatura 6.1 (1990): 55-64. MLA International Bibliography. EBSCO. Web. 20 Apr. 2010. 
Pacheco, Gumersindo. María Virginia está de vacaciones. San Juan, P.R: Editorial Plaza Mayor, 2003.

---Las raíces del tamarindo. Barcelona: Edebé, 2001.

Padura Fuentes, Leonardo. "Vivir en Cuba, crear en Cuba: riesgo y desafío”. La cultura y la revolución cubana: Conversaciones en La Habana. San Juan: Editorial Plaza Mayor, 1999. 321-332

Pardo, María Gracia. Pequeños salvajes: El uso del tropo de la infancia en la construcción del concepto de Latinoamérica. (2009): 1-18.

Pita Rodríguez, Felix. Niños de Viet Nam. La Habana: Gente Nueva, 1968.

Pérez, Louis A. Jr. Essays on Cuban History: historiogrpahy and research. Gainsville: University Press of Florida, 1995.

Perera, Hilda. Cuentos de Apolo. Miami: Franhil Enterprices, 1975.

--- Kike. Madrid: Joaquín Turina, 1998.

Perera, Hilda. “Todos los temas de mi literatura son estrictamente cubanos”. Ellas hablan de la isla. Vitalina Alfonso. La Habana: Unión, 2002.

Puello, Andrés. "Recuerdos de Cuba”. http://www.adpuello.com/

Pupo Pupo, Rigoberto. Identidad, emancipación y nación cubana. La Habana: Política, 2005.

Quiles Cabrera, María del Carmen. "Una aproximación a la narrativa infantil y juvenil cubana actual." Anuario de Investigación en Literatura Infantil y Juvenil 5.(2007): 215-238. MLA International Bibliography. EBSCO. Web. 20 Apr. 2010.

Rama, Angel. La ciudad letrada. New Hampshire: Ediciones del Norte, 1984.

Ribeaux, Ariel. Terreno de nadie. La Habana: Gente Nueva, 2009.

Rodríguez, Antonio Orlando. Panorama histórico de la Literatura Infantil en América Latina y El Caribe. Santafé de Bogotá: CERLAC, 1994.

--- “La Edad de Oro, de José Martí: un clásico”. Serie Profesional del Libro y la Edición. Ed. Luis Rocca Lynn. Santa Fe de Bogotá: CERLAC, 1993. 35-42. 
---“Literatura infantil y juvenil latinoamericana. De los orígenes a los años 1970: algunos hitos y tendencias". Congreso Iberoamericano de Lengua y Literatura Infantil y Juvenil. Ed. Ministerio de Cultura de España. Santiago de Chile: Actas y memorias, 2010. 66-75.

---“Antología de la narrativa infantil cubana”. La Habana: Editorial Gente Nueva, 1996.

Rojas, Rafael. Isla sin fin. Miami: Ediciones Universal, 1998.

Santí, Enrico Mario. "Primera República”. Bienes de siglo sobre la cultura cubana. México D.F: Fondo de Cultura Económica, 2002.

Sommer, Doris. "Irresistible romance: the foundational fictions of Latin America". Foundational Fictions. Berkely: University of California Press, 1991.

Iser, Wolfgang. The Implied Reader: Patterns of Communication in Prose Fiction from Bunyan to Beckett. Baltimore, Md: Johns Hopkins University Press, 1974.

Vázquez Díaz, René. “Crítica de la literatura de compromiso: la cuentística de Manuel Cofiño”. Encuentro. 1 (Verano 1996): 107-12.

Yañez, Mirta. “Tradición y novedades en la literatura para niños en Cuba”. Leitura en Revista. Cátedra Unesco de Leitura PUC-Rio, n.2,abr.,2011. 
VITA

\section{ZEILA FRADE}

Born, La Habana, Cuba

2003-2006

B.A., English

Florida International University

Miami, Florida

2005

Cursos Internationales, Study Abroad

Universidad de Salamanca

Salmanca, España

2006-2008

M.A., Spanish

Florida International University

Miami, Florida

2008-2014

Teaching Assistant and Doctoral Candidate

Florida International University

Miami, Florida

2014

Cuban Heritage Collection Fellow

University of Miami

Miami, Florida

2015

Visiting Professor

Barry University

Miami Shores, Florida

\section{PUBLICATIONS AND PRESENTATIONS}

Frade, Z., (October, 2014). Between the Colony and the Revolution: The Formation of the Cuban Nation Through Children's Literature of the Republic (1902-1958). Paper presented at the Cuban Research Institute, Florida International University.

Frade, Z., (March, 2014) Through the eyes of Apolo: An exploration of social tensions in Republican Cuba. Paper presented at ACLA Annual Meeting, NYU.

Frade, Z., (February 2014) A summer seminar in Spain on Teaching Spanish for Business. Paper presented at $6^{\text {th }}$ Annual K-12 Language for Business Conference, Florida International University.

Frade, Z., (2013) Des-encuentros: El contraste generacional en la literatura infantil cubana postrevolucionaria. Fundación Cuatrogatos.Advance online publication. 